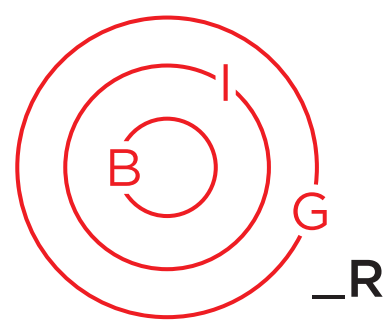

\section{SPECIAL SECTION}

In English

\title{
Art \& Borders: Introduction
}

\section{Art et frontières: Introduction}

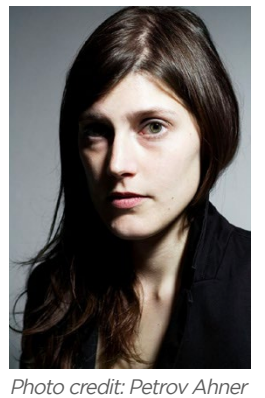
BIG_Review Art Editor Elisa Ganivet introduces
the special section on art and borders.

La rédactrice en chef pour BIG_Review Elisa Ganivet présente la section spéciale sur l'art et les frontières

\begin{abstract}
About the Author
Élisa Ganivet is a doctor of philosophy and art historian. She began her career in 2003, organizing traveling exhibitions of great masters such as Rembrandt, Goya, Calder, Miró, Dali, or Picasso. She works as a consultant for international public and private cultural organizations, and since 2021 she has been in charge of the ADIAF-Marcel Duchamp Prize. Her research in aesthetics, usually in immersion, explore the mechanisms of the utopian idea in phase with societal practice. Her expertise "Border Wall Aesthetics: Artworks in Border Spaces", Transcript Verlag/Columbia University Press, 2019-2020, is the occasion of interventions (Paris 1-Panthéon Sorbonne, LESA Iméra-Marseille, Casa Velázquez-Madrid, European network on cultural management and policy, La Colonie-Paris, France Inter, France Culture...) of publications (Presses du Réel, Presses de l'Université du Québec, Transart Institut, Le Fresnoy...) and curatorships (Instituts français, European Union National Institutes for Culture...). She has been the editorial coordinator for the artist Kader Attia. She is a member of the AICA (International Association of Art Critics).
\end{abstract}

BIG_Review journal homepage: https://journals.uvic.ca/index.php/bigreview Borders in Globalization homepage: https://biglobalization.org/

\section{Elisa Ganivet}


I'm writing to you from a place of transit, sitting in a plane when, for ecological reasons, I would have preferred to be in a train but the tickets cost double. I am writing to you from a privileged place, while tragedies follow one another at the borders, just as we are flying over the Mediterranean Sea. This scandalous tomb attributed to whom? To whom? The question arises as each one of us shirks our responsibilities.

For the Art and Borders section, all my thanks and my gratitude go to Emmanuel Brunet-Jailly who was of unfailing support at the earliest stage of the publication of my research on the aesthetics of the geopolitical wall, initially supported by Elisabeth Vallet. My special thanks go to Michael J. Carpenter, who, from a great distance-technological joy-accompanied me in my deliberations, as well as to Benjamin Perrier who with equal kindness, revised the French texts. And of course I am grateful to the University of Victoria for allowing us this publication

Writing grants us a boundless freedom. To do this, I proposed to several artists, curators and an authorcritic to express themselves on the theme that brings us together here, that of borders. Today this notion, victim of its success, is used to all coming. Everything has become a border. All the more so with the crisis of COVID which tends to justify a permanent state of alert, constraining our bodies and our rights. To make the exceptional a norm is an arrangement to which we must remain vigilant, if only for the sake of our children's upcoming freedom.

The doctoral research pushed me to a neutrality and a distance towards the artists that I basically admired. The advantage of not being attached to it anymore is that I can now conduct more subjective interviews. At your convenience, you will read here unpublished texts especially conceived for BIG_R, as well as interviews with artists who have marked me these last ten years, as much by the coherence as by the dialectical depth employed on the border subject. I would like to warmly thank them for their trust and their generous contribution.

The invitation made to the curators of the Zeppelin Museum of Friedrischafen in Germany provides an extended dimension. Because for having lived in Berlin for so many years in order to understand the mechanisms of the Berlin Wall and its aesthetic application, we have here a fascinating journey into airspace also constitutes geopolitical ambitions. Their curatorial proposal is to be commended here. Besides seen from the post-photographic sky of Google, the border becomes a blurred line without history, and provocative of dehumanization, as Hélène Mutter will tell you, having contributed an essay in French about her work Lines.
Je vous écris depuis un lieu de transit, assise dans un avion alors que, par conscience écologique, j'aurais préféré être dans un train mais les billets coutaient le double. Je vous écris depuis un endroit privilégié alors que se succèdent les tragédies aux frontières, justement au moment où nous survolons la mer méditerranée. Ce scandaleux tombeau attribué à qui ? A qui ? La question se pose puisque chacun se défait de ses responsabilités.

Pour la section Art et Borders, tous mes remerciements et ma reconnaissance s'adressent à Emmanuel Brunet-Jailly qui fut d'un appui sans faille au plus tôt de la publication de mes recherches sur l'esthétique du mur géopolitique, initialement soutenue par Elisabeth Vallet. Mes remerciements vont également spécialement à Michael J. Carpenter, qui, toutes oreilles lointaines (joie technologique), m'accompagna dans mes délibérations, ainsi qu'à Benjamin Perrier qui avec autant de bienveillance, révisa les textes. Et bien sûr je suis reconnaissante envers l'Université de Victoria de nous permettre cette publication.

L'écriture nous octroie une liberté sans bornes. Pour ce faire, j'ai proposé à plusieurs artistes, curateurs et à un auteur-critique de venir s'exprimer sur la thématique qui nous réunit ici, celle des frontières. Aujourd'hui la notion frontalière, victime de son succès, est employée au tout venant. Tout se convertit en frontière, d'autant plus avec la crise de la COVID qui tend à justifier un état d'alerte permanent, contraignant nos corps et nos droits. Faire de l'exceptionnel une norme est un agencement auquel il nous faut rester vigilant, ne serait-ce que pour la liberté prochaine de nos enfants.

La recherche doctorale me poussait à une neutralité et à une distance vis-à-vis des artistes qu'au fond j'admirais. L'avantage de n'y être plus attachée est de pouvoir dorénavant mener des interviews plus subjectives. Vous allez lire ici, à votre bon vouloir, des textes inédits spécialement conçus pour BIG_R, ainsi que des interviews avec des artistes qui m'ont marqués ces dix dernières années, tant par la cohérence que par la profondeur dialectique employée sur le sujet frontalier. Je tiens chaleureusement à les remercier de leur confiance et de leur généreuse contribution.

L'invitation faite aux curateurs du Zeppelin Museum de Friedrischafen en Allemagne procure une dimension élargie. Car pour avoir vécu à Berlin autant d'années afin de comprendre les mécanismes du mur de Berlin et de son application esthétique, c'est ici un fascinant voyage de ce que l'espace aérien constitue également d'ambitions géopolitiques. Leur proposition curatoriale doit être saluée.

D'ailleurs vu depuis le ciel post-photographique de Google, la frontière devient une ligne floue sans histoire et provocante de déshumanisation, comme vous le signalera Hélène Mutter. 
The ground of the border wall was and will always be bypassed. Gunter Grass reports to us about his significant and timeless experience as a smuggler: "One of the escape routes, which went from the city center to Kreuzberg, we called Glockengasse 4711, like on the cologne bottles, because we were all, smugglers and refugees, walking in shit up to our knees. Later on, I was the 'lid'. As soon as people were on their way, I would replace the lid to the entrance, since the last fugitives were so panicked they forgot to close it."

Does the anecdote make history, is it legitimate matter of historical understanding? I do not know. Simply, having experienced the physical Moroccan border myself (this arm of the sea), having lived in Tangier with other implicit borders that clash with my own identity, the visual encounter with Randa Maroufi revealed this ambivalent feeling. I let you discover here the border transversality of her approach, voraciously relevant.

Christian Gattinoni, for his part, proposes a tour of the Fotolimo Festival where the geographical situation, on the French-Spanish-Catalan border, is subject to judicious photographic invitations.

Emeric Lhuisset's work is a major contribution to our understanding of conflict zones. His anthropological, even psychoanalytical positioning makes us accessible to refugees, rebels, fighters (Kurds, Farc, Taliban...) whose words are usually denied because they are melted into the media mass. His approach, combined with his specific photographic treatment or staging, recomposes the singular destiny of people who make history.

The original uprooting of Taysir Batniji from a homeland denied is the fruit of a sensitive and powerful work. Making the personal a more universal language is a tour de force that you can read here in an interview unvarnished.

And it is quite logical that his work on the in-between returns to my mind an ode to the mestizo language. Dual culture is by birth appropriated or conceptualized by the force of (often dramatic) events.

\footnotetext{
"Una lucha de fronteras / A struggle of Borders

Because I, a mestiza

continually walk out of one culture

and into another;

because I am in all cultures at the same time,

alma entre dos mundos, tres, cuatro,

me zumba la cabeza con lo contradictorio.

Estoy norteada por todas las voces que me hablan

Simultáneamente" (Anzaldúa 1987, 99).
}

Alors que le terrestre du mur frontalier fut et sera toujours contourné. Gunter Grass nous racontait son expérience, significative et intemporelle, en tant que passeur : «Un des itinéraires de fuite, qui allait du centre-ville à Kreuzberg, on l'appelait Glockengasse 4711, comme sur les flacons d'eau de Cologne, parce que tout le monde, nous comme les réfugiés, on marchait dans la merde jusqu'aux genoux. Plus tard, j'ai été "couvercle", dès que les gens étaient en route, je rajustais le couvercle de la bouche, parce que les derniers fugitifs étaient souvent pris de panique et oubliaient de le refermer» (Grass 1999, 208-209).

Est-ce que l'anecdote fait l'histoire, est-elle matière légitime de compréhension historique ? Je l'ignore. Simplement, pour avoir moi-même expérimenté la frontière physique marocaine (ce bras de mer), pour avoir vécu à Tanger d'autres frontières implicites jurant avec ma propre identité, la rencontre visuelle avec Randa Maroufi a été révélatrice de ce ressenti ambivalent. Je vous laisse ici découvrir la transversalité frontalière de son approche, voracement pertinente.

Christian Gattinoni, quant à lui, vous propose un tour au Festival Fotolimo où la situation géographique, à la lisière franco-espagnole-catalane, est sujet à de judicieuses invitations photographiques.

L'œuvre d'Emeric Lhuisset est majeure dans notre compréhension sur les zones de conflit. Son positionnement anthropologique, voire psychanalytique nous rend accessible des réfugiés, des révoltés, des combattants (kurdes, Farcs, talibans...) dont la parole est habituellement niée car fondue dans la masse médiatique. L'esthétisation par son traitement photographique spécifique ou de mise en scène, recompose le destin singulier de personnes qui font histoire.

Le déracinement originel de Taysir Batniji est fruit d'une œuvre sensible et puissante. Faire du personnel un langage plus universel est un tour de force que vous pourrez ici lire dans une interview sans fard.

Et c'est assez logiquement que son travail sur l'entredeux me renvoie à l'esprit une ode au langage métisse. La double culture est de naissance appropriée ou conceptualisée par la force des événements (souvent dramatiques).

« Una lucha de fronteras / A struggle of Borders

Because I, a mestiza

continually walk out of one culture

and into another;

because I am in all cultures at the same time, alma entre dos mundos, tres, cuatro, me zumba la cabeza con lo contradictorio. Estoy norteada por todas las voces que me hablan Simultáneamente » (Anzaldúa 1987, 99). 
Enjoy your reading and thank you for reading us.

More in the next issue.

\section{Works Cited}

Grass, G. 1999. Mon siècle. Paris: Seuil.

Anzaldúa, G. 1987. Borderlands/La Frontera: The New Mestiza. San Francisco: Aunt Lute Books.
Bonne lecture et merci à vous de nous lire.

La suite au prochain numéro.

\section{Bibliographie}

Grass, G. 1999. Mon siècle. Paris: Seuil.

Anzaldúa, G. 1987. Borderlands/La Frontera: The New Mestiza. San Francisco: Aunt Lute Books.. 


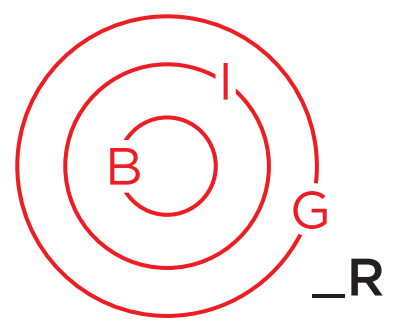

ART \& BORDERS

\title{
Beyond Borders, Beyond States: Artistic and Historical Aviation Perspectives
}

\author{
Ina Neddermeyer ${ }^{i}$ and Jürgen Bleibler ${ }^{\mathrm{ii}}$
}

Proceeding from the historical question of the regulation of airspace, this essay examines the current and future significance of borders and the central question of statehood, for the special section of this issue, Art \& Borders. The authors draw on their experience as curators of the 2021 exhibition Beyond States: The Boundaries of Statehood at the Zeppelin Museum in Friedrichshafen, Germany, to reveal the role of ballooning aviation and critical approaches of artists towards border regimes.

\section{Introduction}

In times of global markets and networks, progressing digitalisation, and the rise of supranational organisations, worldwide migration movements are no longer the exception but the rule. A development that poses great challenges to nation states. In this context, dissolving and simultaneously solidifying borders are central elements in the reflection on the multi-layered processes surrounding migration and statehood.

Besides their role as political and territorial instruments, borders are also determined by cultural, economic, social, and political reciprocity. As manifestations of a process, they impact national, social, and cultural structures of the present, past, and future with individual and collective perspectives that must be brought to light (Gerst et al. 2021).

Proceeding from the historical question of the regulation of airspace, this essay examines the current and future significance of borders and the central question of statehood.

\section{Border Violations and Confusions in the Sky: 18th Century Ballooning}

The question of drawing borders in the sky became relevant with the first forays into the third dimension with hot-air and gas balloons in 1783. Neither were steerable but became the basis for steerable motorised airships in the 20th century, which were soon rivalled by airplanes. Aviation was one of the most defining developments of the 20th century. As the epitome of modernity, it fundamentally changed mobility, science, and wars and provided a new perspective on Earth.

This view from above was glorified as the fulfilment of an ancient dream of mankind and associated with the desire to fly and freedom, but also represented the striving for technological superiority, the exercise of power, and conquest. Rooted in antiquity, the theoretical question of whether borders on the ground should extend to the sky became a concrete discussion about regulations in the wake of aviation (Otto 2017, 15-32).

i Ina Neddermeyer studied art history, political science, and philosophy in Berlin and Florence. From 2013 to 2016 she was the curator of the Municipal Art Collection at the Kunstpalais in Erlangen. Since 2016 she has been the curator and head of the art department of the Zeppelin Museum Friedrichshafen.

ii Jürgen Bleibler studied library science, art history, and German studies in Stuttgart and Saarbrücken. Since 1998, he has been the curator and head of the Zeppelin department of the Zeppelin Museum in Friedrichshafen. 


\section{Evolution of Nation-States and Demarcations in Airspace}

In the 19th century, ballooning for military, scientific, or sporting purposes was the only practicable form of flying. Under favourable meteorological conditions, spherical balloons filled with hydrogen could cover distances of over 1,000 kilometres. But as neither the course nor the destination could be influenced, balloons went where the wind took them. Record and longdistance flights inevitably resulted in border crossings that often led to complications. On the ground, the appearance of balloons, especially over border fortifications and military installations, reinforced the unpleasant feeling of being at the mercy of surveillance from above. After landing, balloon crews were thus often confronted with accusations of espionage. The fact that many officers not only indulged in ballooning for competitive reasons further stoked these situations. Of course, the diplomatic climate between the state from which a balloon had set off and that in which it landed influenced the assessment of the situation. To avoid complications, participants in balloon races were legitimised with officially stamped multilingual membership cards.

In the 19th century, the formation of new nation-states required a basic regulation of the conception of national sovereignty. With the beginnings of aviation, airspace presented a new sovereignty issue that triggered a constitutional discourse.

Before the First World War, the controversy over the legal regulation of airspace was defined by two conflicting views. Those who advocated a national division were opposed by those in favour of an open sky. The main argument for the latter was that states could neither control nor defend their airspace, a theory the events of the First World War soon disproved.

The perception of balloons as threats to the sovereignty of states decreased with the advances in aviation technology. The focus had shifted to airships and airplanes. Besides idealistic hopes for a new form of transportation that would help to overcome borders and bring people together, the military potential of flying was the driving force. While aviation was taking shape as a new military option, the major European powers were engaged in a national prestige and arms race. In this political climate, flying reinforced the mutual distrust at state borders and stoked the fear of attacks from the third dimension.

Military decision makers in all states believed that airships and airplanes would aid the war on land through aerial reconnaissance. Due to their initially superior ranges and payloads, airships also gave rise to considerations on bombing. The discourse in international law about this new form of warfare is reflected in a ban imposed at the first Hague Peace
Conference in 1899. However, at the conference in 1907 it was lifted since none of the active nations wanted to relinquish this military advantage. The first step towards a potential aerial war without boundaries had thus been taken.

\section{Zeppelins as German Symbols of Power: Nationalism and Claims to Power Beyond Borders}

In the race for dominance in the third dimension, the German Empire mainly relied on the Zeppelin airships, which were built up by the media as a threat against France, and even more so, against Great Britain. On 1 July 1908, the Zeppelin airship LZ 4 flew from Lake Constance to Lucerne in Switzerland and back in twelve hours and made international headlines with this first transnational long-distance flight with a steerable aircraft. The unannounced intrusion into the airspace of a sovereign neighbour state was an unmistakable signal of the claim to power in the third dimension. It was not directed at Switzerland but caused alarm in the British Isles and unsettled the sense of absolute safety the nation's protected island position and the Royal Navy had provided for centuries. Reports of Zeppelins allegedly crossing over England to prepare for an imminent German invasion promptly started to amass. With the Aerial Navigation Act of 1911 as a direct response to the new threat, the British government was the first to pass a law on the closure of its own airspace (Otto 2017, 32).

In Switzerland, the state directly affected by Germany's border violation, the reactions were carried by a wave of Zeppelin euphoria any bit as enthusiastic as that in Germany. Even when LZ 4 crossed over military premises the officers responded with friendly waves. Nor did the Swiss government show any negative reactions, thus confirming their conflict-free diplomatic relationship with the German Empire. Only the Swiss Social Democrats referred to the flight as a violation of the country's sovereignty. For this they were instantly reprimanded by the SPD of Baden and Württemberg, who quickly persuaded their comrades in Switzerland to comply with the interpretation of the Zeppelin airship as an instrument of fraternisation between the two nations (Haude 2014, 9-15).

The 24-hour endurance fight of the LZ 4 on 4/5 August 1908 was a threatening gesture clearly directed against France. The mass circulation of images of the Zeppelin with the Strasbourg Munster was intended to reinforce the claim to Alsace-Lorraine, which had become part of the German Empire through an annexation during the Franco-Prussian War of 1870/71 [Figure 1]. Surprisingly, the destruction of LZ 4 in Echterdingen did not lead to technological disenchantment but to a "Volksspende (Donation of the People)", which manifested the collective identification with the popular "Airship Count". 
Borders in Globalization Review | Volume 3 | Issue 1 | Fall/Winter 2021

Neddermeyer \& Bleibler, "Beyond Borders, Beyond States: Artistic and Historical Aviation Perspectives"

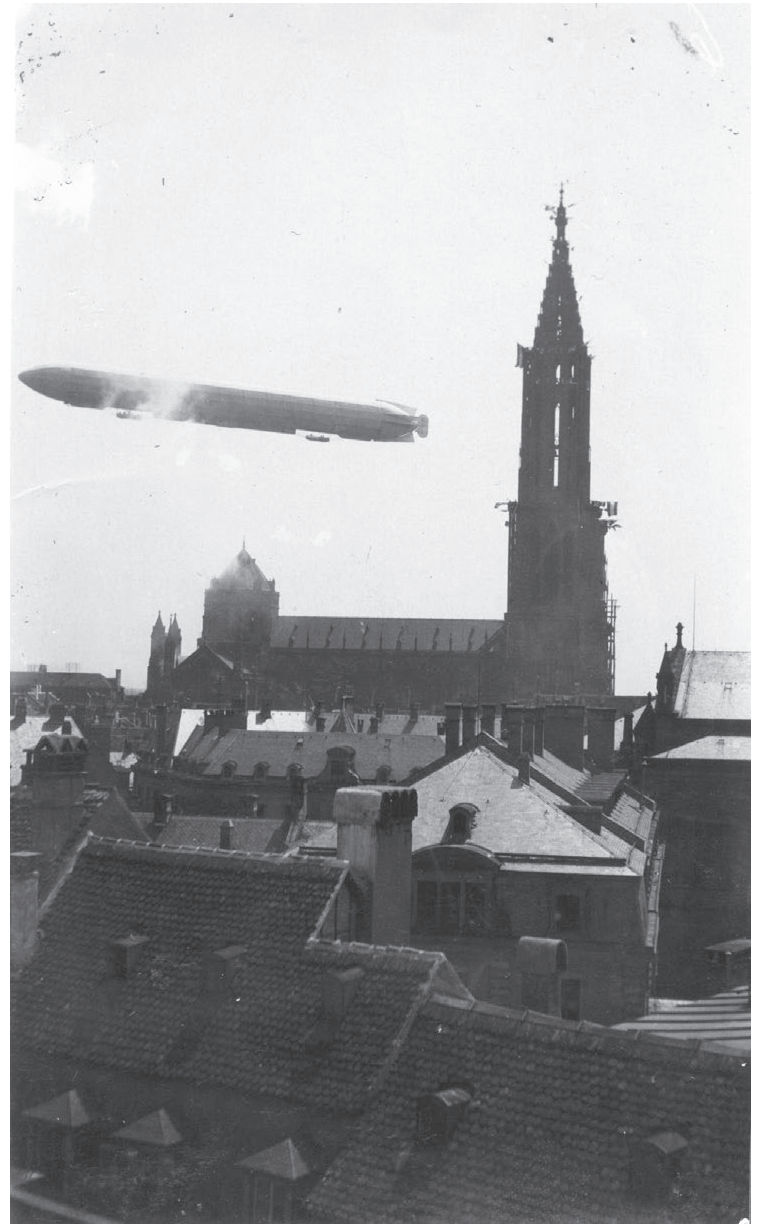

Figure 1. LZ 4 over Strasbourg 1904. (A) Archiv der Luftschiffbau Zeppelin $\mathrm{GmbH}$.
In addition to its external significance, the Zeppelin airship had gained an internal function as a symbol of national identity which helped to gloss over social conflicts and justify armament expenditures (Zeising 1998, 75-98).

\section{The Lunéville Incident of 1913}

The heated atmosphere at the French-German border became especially manifest in the Lunéville Incident of April 1913 [Figure 2]. On its way from Friedrichshafen to Baden-Oos, the army Zeppelin Z IV had gotten off course in the fog and was forced to make an emergency landing in Lunéville, France. While the French suspected espionage, the Germans were faced with the problem that the Zeppelin technology, a protected state secret, lay exposed on French territory where it could be photographed without hindrance and examined by experts in detail (de Syon 2001, 41-53).

The accusation of espionage was invalidated by the lack of cameras on board and the French accepted the loss of orientation as an explanation. However, this display of hopeless disorientation was extremely embarrassing for the German side and shook both the German military's and the public's faith in the Zeppelins' military adequacy. The reactions in the French populace were very hostile. One specific reason was that before landing, tools and spare parts had been thrown off $Z$ IV to shed ballast and had damaged some houses. In combination with the German propaganda's image of the airships as offensive weapons in a future war, this further fuelled the negative mood of the French.

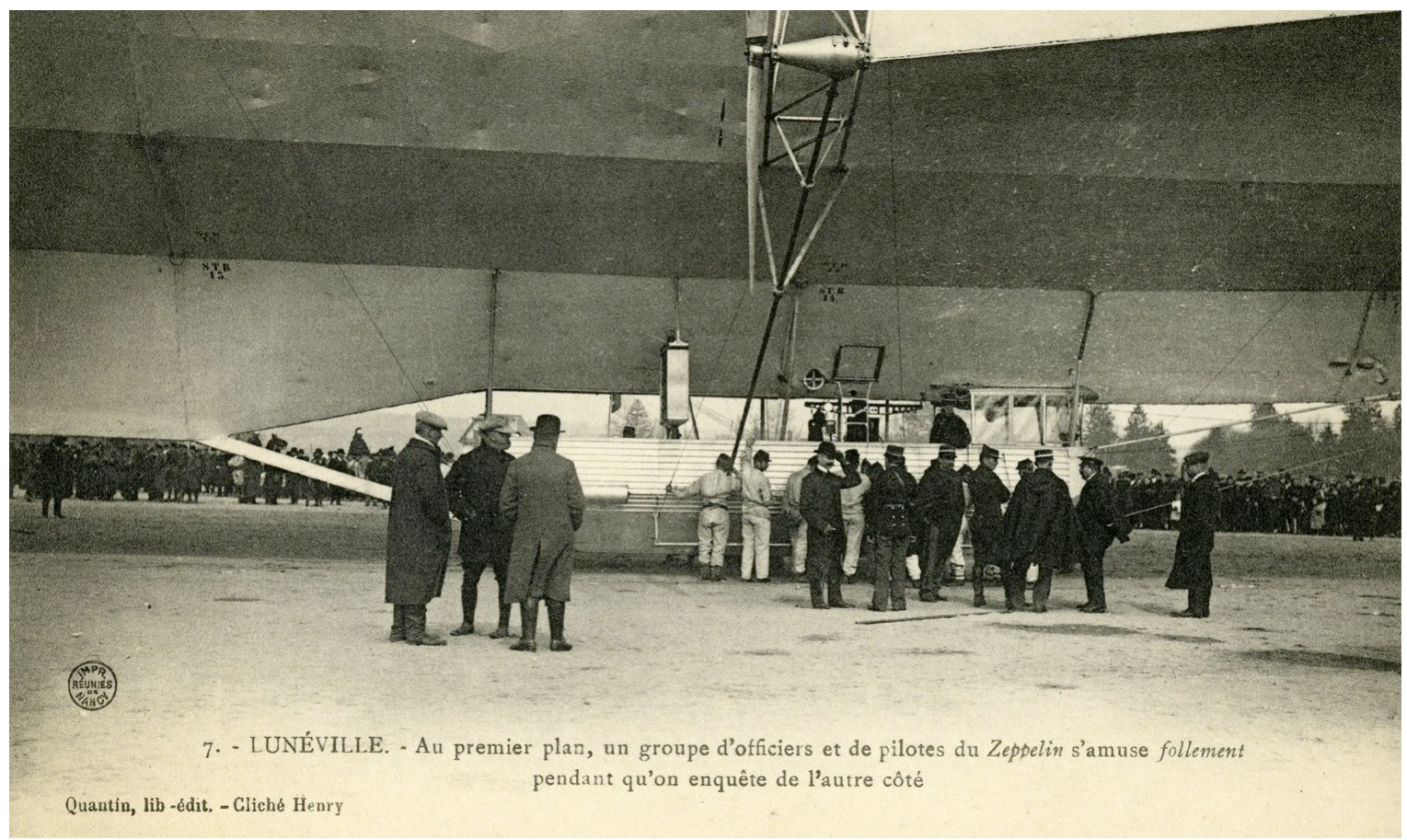

Figure 2. Lunéville incident 1913. ( $)$ Zeppelin Museum Friedrichshafen GmbH. 
Since 1900, the legal problems surrounding airspace such as national claims to sovereignty, open or closed airspace, liability in accident cases or field damage, violent offences on board aircraft, or dropping bombs in the event of war had become topics of discussion. The first initiatives for regulations came from France. As in Germany, confidence in the nation's technological superiority initially led to a preference for an open sky, in contrast to Great Britain. The need for a regulation of air traffic through international laws became apparent long before it was practicable. In 1910, a first exploratory conference was held in Paris. At the same time, the situation called for bilateral solutions between states, in which the distinction between civilian and military flight movements but also the political climate between the neighbours played an important role. In August 1913, a French-German aviation agreement was signed that regulated the obtainment of flyover permits and no-fly zones. However, it was hardly brought into action before the outbreak of the war. In 1919, by which time air traffic had become a realistic option due to the technological progress during the First World War, the decision was made to regulate airspace according to nation-states, which is still largely the case today.

\section{The First World War: Aerial Warfare without Boundaries and Civil Protection}

In the First World War, rigid airships of the Zeppelin and Schütte-Lanz construction type with their wide ranges and payloads revolutionised the possibilities of warfare by taking it far into the hinterlands of other states for direct attacks on industries, infrastructures, and civilian populations. Liège, Antwerp, Paris, and other cities were assailed by German airships, while German cities had already been targeted by French airplanes in 1914. Germany's strategic aerial war against previously unassailable Great Britain also played a special role in terms of war propaganda.

In May 1915, the first Zeppelin bombs were dropped on London. However, the pressure of increasing airship losses led to their replacement with airplanes from 1917 onwards. Airplanes were faster and cheaper to produce and required less professional and infrastructural effort. The First World War saw the escalation of this kind of aerial war across borders and great distances, which developed increasingly horrific dimensions. This advancement of aviation and weapons technology resulted in the death of countless civilians, first in the Spanish Civil War and subsequently during the Second World War.

This new form of attack from the third dimension raised the question of how to defend national airspace as well as civilian populations. Besides the establishment of defensive air forces, this included and continues to include the construction and maintenance of air-raid shelters, warning the population, and provisions for rescue measures, such as the recovery of people buried alive under rubble [Figure 3 ].

\section{Demarcations after 1945: The Cold War}

Since the 1950s, the development of intercontinental air traffic had gained dynamism and became a global means of mass transportation and an essential precondition for

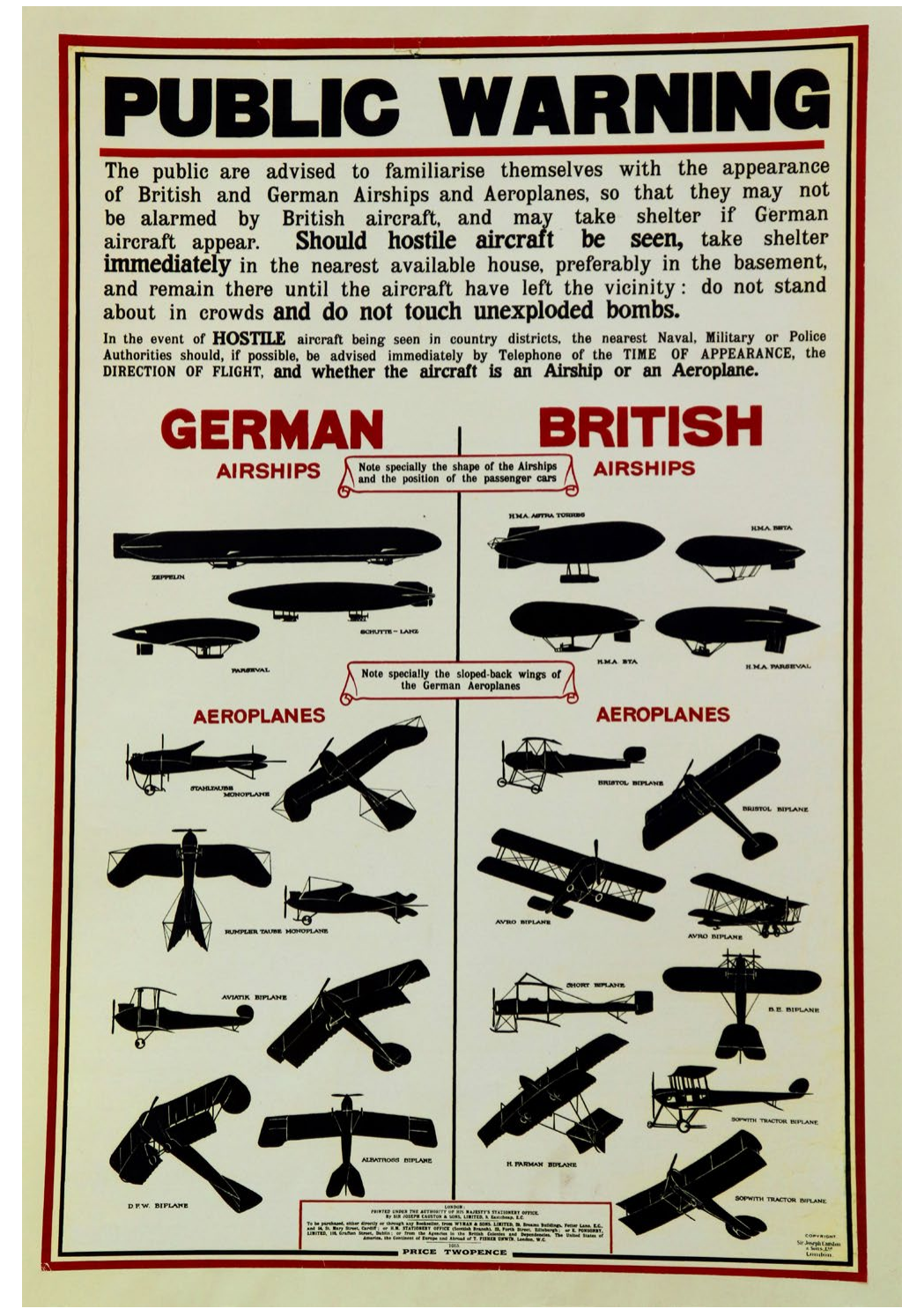

Figure 3. Public Warning (1915). ( $)$ Zeppelin Museum Friedrichshafen GmbH. 
globalisation in the 1970s. At the same time, the Cold War had drawn a new border through Europe which was also insurmountable in the sky. The two power blocs faced one another heavily armed with both conventional and nuclear weapons, which frequently triggered dangerous provocations and incidents. During the Cold War, attempts to transcend borders from the German Democratic Republic and other states by air were also made using the simplest means, such as home-made hot-air balloons. In 1987 Matthias Rust made headlines when he managed to enter the airspace of the USSR undetected from Finland and landws his hot-air balloon in the Red Square. More than ever, air traffic requires international and global conventions and is affected by every political, social, or cultural border shift, especially when a conflict is carried out with violent means.

\section{Fluid Demarcations}

Demarcations were not only contested in the sky. To this day, borders on water are not always clearly defined. In her work Border Sampling [N $47^{\circ} 37^{\prime} 26^{\prime \prime}$ E $9^{\circ} 22^{\prime}$ 32"'] Nevin Aladağ ponders questions of demarcation and state sovereignty by exploring Lake Constance as international boundary waters connecting Germany, Austria, and Switzerland. In some areas, the precise course of the border remains unclear [Figure 4]. From the German perspective, the Obersee, the Upper Lake, is a condominium, in other words, common territory beyond the shore. In accordance with common law, everyday life on Lake Constance is regulated by the International Lake Constance Conference which coordinates environmental and water protection across the borders. At the deepest point of Lake Constance, which is common sovereign territory, Aladağ took water samples and thereby exposed the paradoxical notion of water with its fluid mobility as a linear boundary mark [Figure 5]. The artist thus reflects on questions of border demarcation and state sovereignty.

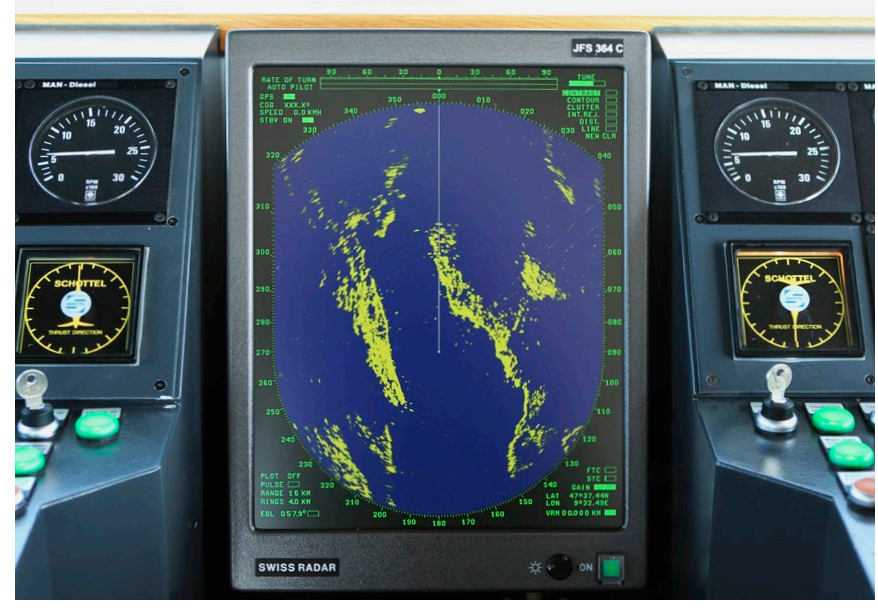

Figure 4. Nevin Aladag, Border Sampling, 2011. ( ) Nevin Aladağ, ZF Kunststiftung, VG Bild-Kunst 2021

\section{Militarised Border Regions}

Forensic Oceanography's work Mare Clausum-The Sea Watch vs Libyan Coast Guard Case (2018) deals with the militarised border region in the Mediterranean and shows how quickly fluid borders can became deadly danger zones. The collective analyses the spatial and political conditions that lead thousands of refugees to drown in the Mediterranean. This work is dedicated specifically to a grave incident that occurred on 6.11.2017 when the NGO Sea-Watch e.V. and the Libyan Coast Guard were called to save a boat carrying 130 migrants. Some of the refugees hoped to evade the Libyan catchers by swimming to the Sea-Watch rescue vessels. Sea-Watch managed to save 59 people who were taken to Italy. However, 47 people were taken back to Libya where they suffered severe human rights violations. At least 20 people died before and during the rescue operation [Figure 6].

Created with a selection of geodata, shipping data, models, video material from Sea-Watch e.V., eyewitness accounts, and leaked documents from the European Union Naval Force Mediterranean, the video reconstruction is a poignant illustration of the deadly effects of the EU's migration policies [Figure 7]. It is part of the "Mare Clausum" report by Forensic Oceanography, which served as the basis for a legal complaint against Italy at the European Court of Human Rights. For many years, the European Union has been externalising its border controls which recurringly leads to severe human rights violations. Despite its extensive budget, the European Border and Coast Guard Agency (Frontex) hardly conducts any rescue operations at sea; for context, in 2020 Frontex had a budget of $€ 460$ million (Monroy 2021). On the contrary, Frontex is frequently accused of being involved in illegal pushbacks and ignoring human rights standards. Moreover, the increasing criminalisation of civilian sea rescue missions has made the situation in the Mediterranean extremely dangerous.

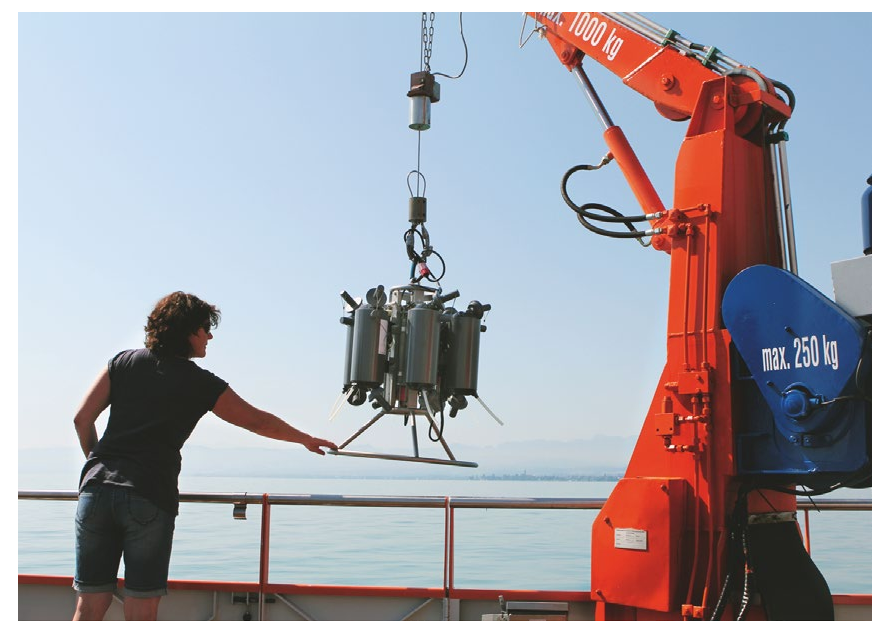

Figure 5. Nevin Aladag, Border Sampling, 2011. (c Nevin Aladağ, ZF Kunststiftung, VG Bild-Kunst 2021 


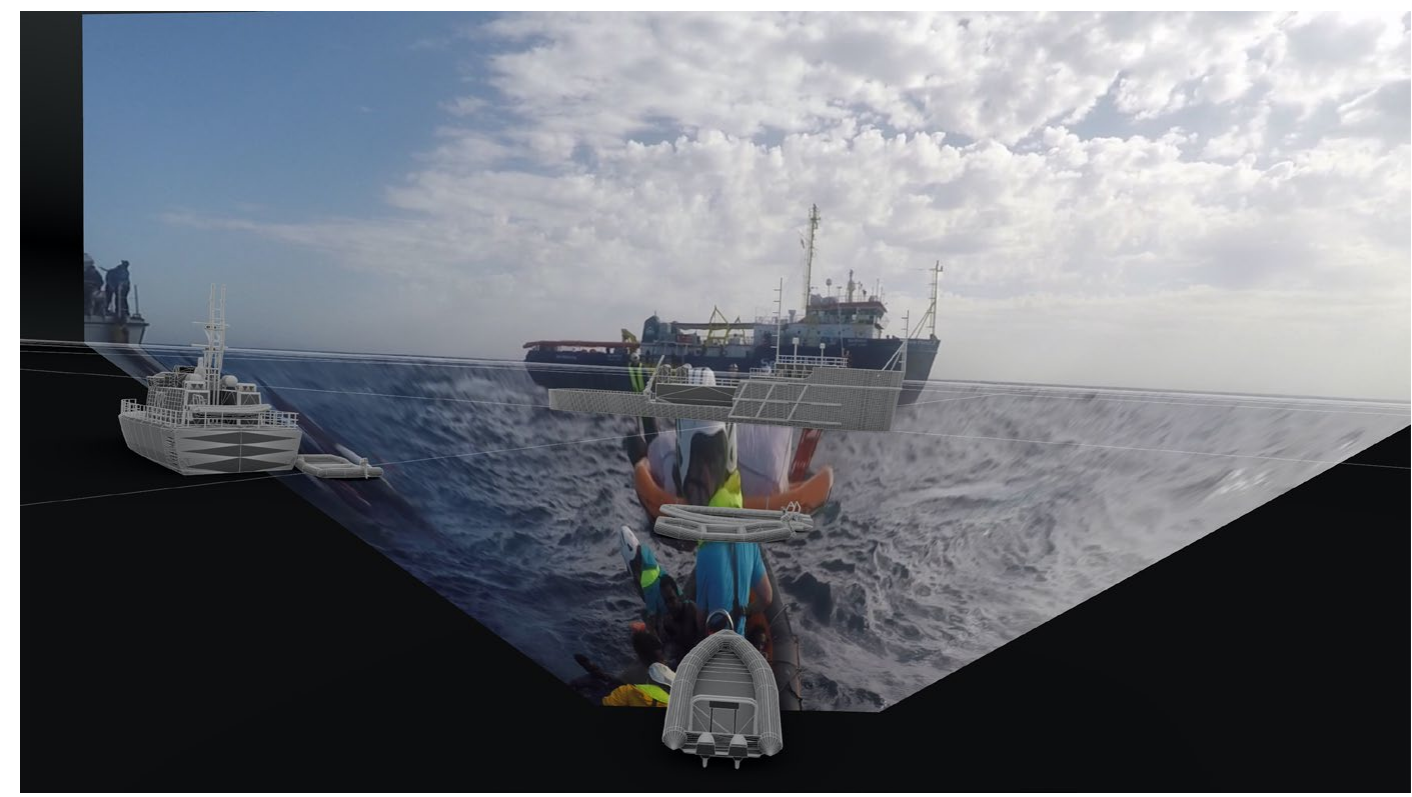

Figure 6. Forensic Oceanography and Forensic Architecture, Mare Clausum-The Sea Watch vs Libyan Coast Guard Case (2018, 28 min.). An image projected onto a 3D model in order reconstruct the complicated scene of search-and-rescue operations by the Libyan Coastguard and NGO vessels on 6 November 2017. (c) Forensic Oceanography and Forensic Architecture, 2018.

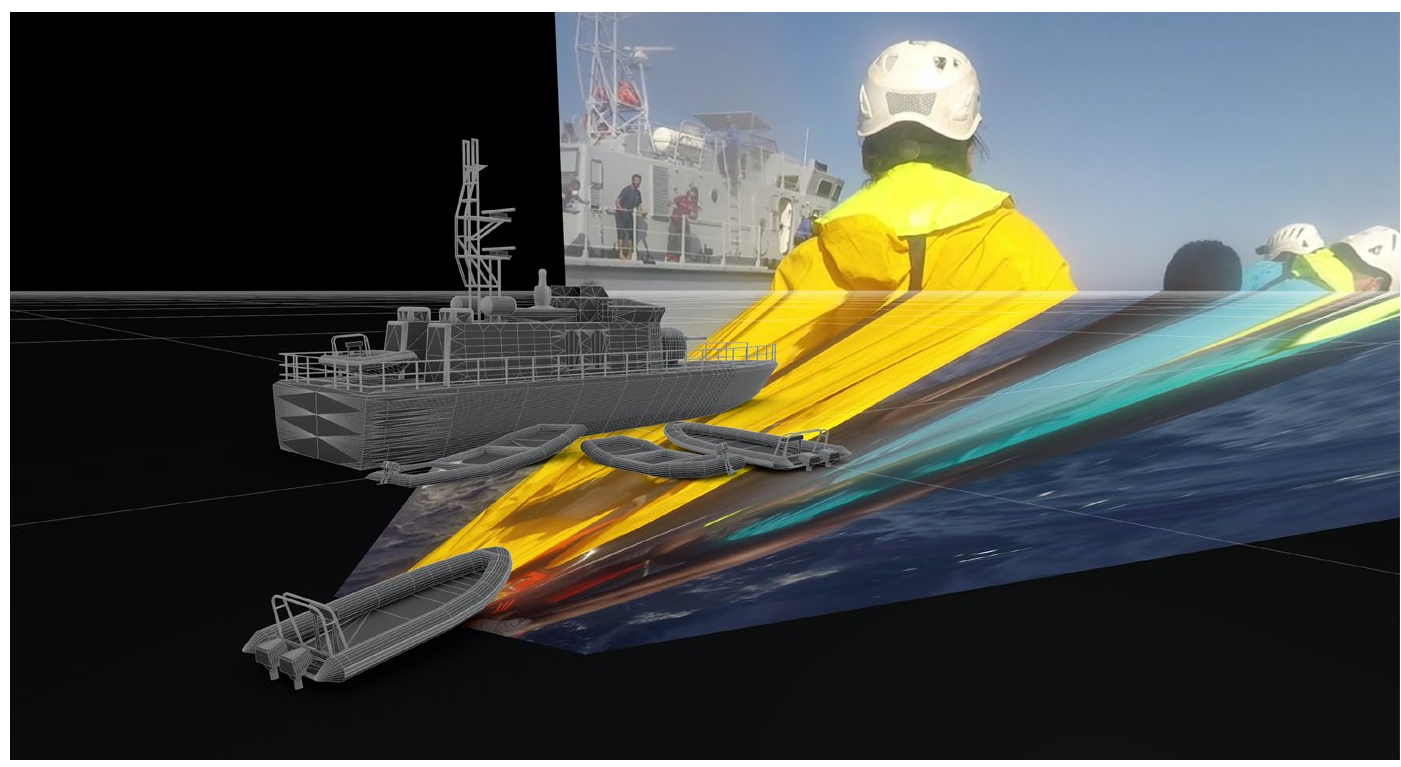

Figure 7. Forensic Oceanography and Forensic Architecture, Mare Clausum-The Sea Watch vs Libyan Coast Guard Case (2018, $28 \mathrm{~min}$.). A reconstruction of the altercation of search and rescue operations in the central Mediterranean on 6 November 2017. ( F Forensic Oceanography and Forensic Architecture, 2018.

Forensic Oceanography's video installation reveals the failure of government institutions in the countries thousands are forced to flee from due to their extreme economic and political situations, the Libyan Coast Guard and its increasing use of violence against migrants, and the inability of the European border states to find a humanitarian solution. Charles Heller (Forensic Oceanography) strongly advocates legal and safe refugee routes and refers to the bigger picture in which migration is a manifestation of socio-economic problems:
From my perspective, the last 30 years of policies of border closure demonstrate how utopian it is to try to seal borders and prevent mobility. If those politics could work, I think we would know it after 30 years. They failed miserably. They only generate further human suffering, but also political crises. I think it is much more effective to start from the fact of human movement. That is the reality. Give a legal frame for that human movement to unfold and really try to tackle the broader political economic conflicts and inequalities that today make migration so contentious (Heller 2021). 


\section{How to Overcome Borders: Flexible Citizenship}

The question of how to overcome borders and establish new forms of citizenship concerns many artists. All over the world, citizenship is still tied to nation-states. But what shape could a flexible kind of citizenship take?

In their video, Jacob Hurwitz-Goodman and Daniel Keller critically explore the Seasteading Institute which wants to establish autonomous communities on swimming platforms on international waters [Figure 8]. They propagate a new kind of settlement (ocean instead of land grabbing) beyond national borders. What initially seems like a both utopian and progressive project geared towards enabling new forms of coexistence, turns out to be a neoliberal idea mainly motivated by tax evasion. The governments of the new microstates resemble businesses on a free market where citizens can choose their favourite society.

Christopher Kulendran Thomas and Annika Kuhlmann went one step further with their examination of postcapitalist societal models beyond national borders. They developed a housing proposal that combines the idea of a flexible network-like state as an alternative to a territorially limited nation with design concepts. The work was inspired by the lost stories of the home country of Kulendran Thomas's family. Once a part of Sri Lanka, Tamil Eelam was in effect an autonomous state self-governed by a neo-Marxist revolution for decades before it was wiped out with the brutal end of the Sri Lankan civil war in 2009.
Kulendran Thomas and Kuhlmann studied the work of the revolutionary Tamil architect Manmahal (மண்மகள்). During the time of Tamil Eelam, her ideas for a flexible, decentralised housing network envisioned a future beyond the caste system and other social forms imposed under British colonial rule. Manmahal's designs for a flexible furniture system were reinterpreted in collaboration with the Berlin designers NEW TENDENCY [Figure 9]. The concept is based on a single joint that can be combined with locally available materials to construct a variety of furniture. The underlying idea of transnational mobility functions beyond national borders. Flexible citizenship and design are interpreted as a mutually influential unity.

\section{Beyond Border, Beyond States}

The past years have seen a worldwide transformation process in which classic border security policies are being replaced by smart border management. This development is accompanied by an increased technologization of borders enhanced by robotics and artificial intelligence. However, this is where the basic conflict soon becomes apparent: the paradoxical endeavour of securing borders while trying to enable as much mobility as possible at the same time (Pötzsch 2021, 283-296).

Not only Christopher Kulendran Thomas, but also the artist Jonas Staal, explores decentralised forms of coexistence. In 2012, Staal initiated the New World

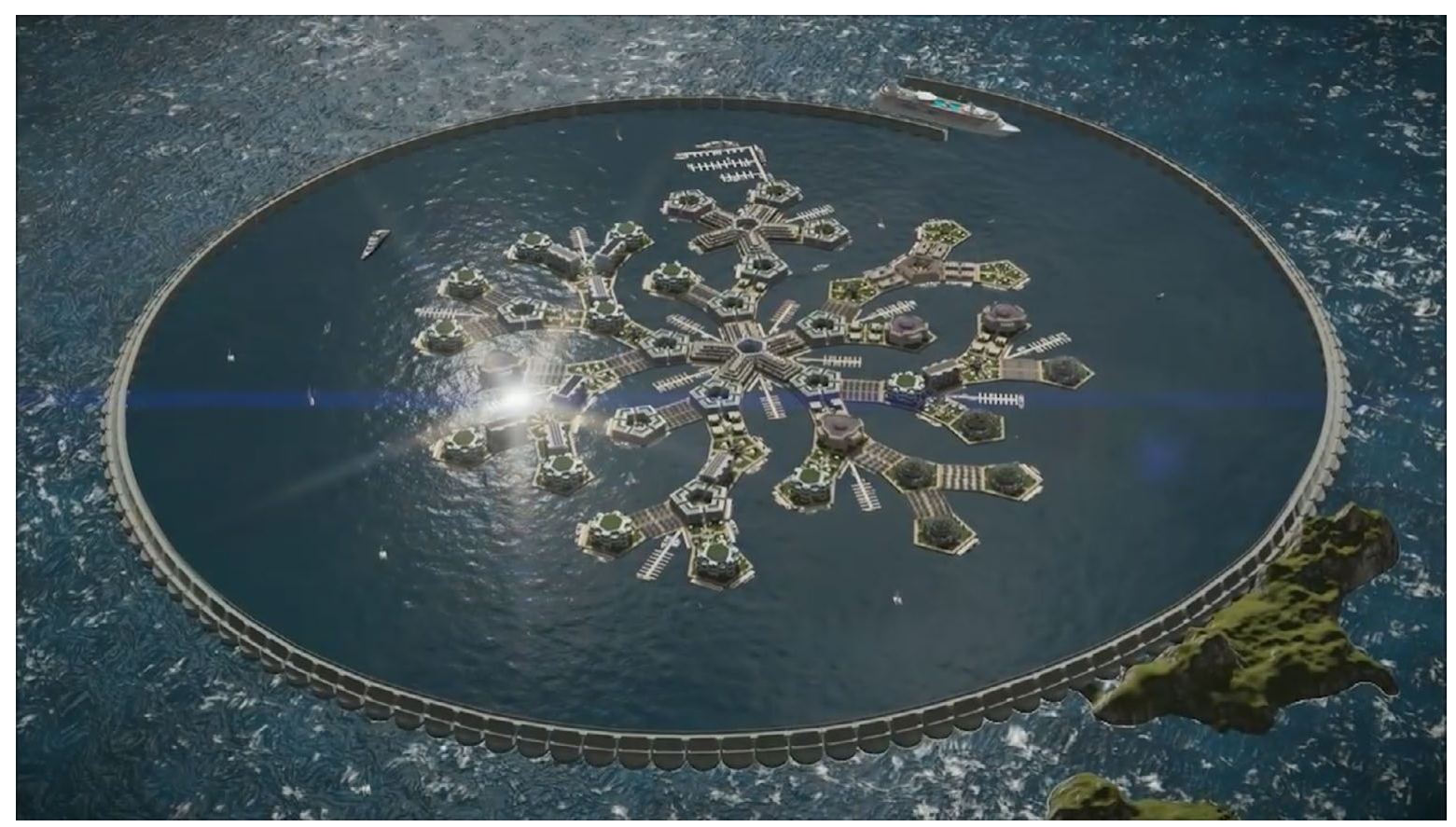

Figure 8. Jacob Hurwitz-Goodman \& Daniel Keller, The Seasteaders (2018, 28 min.). The. video still shows a preliminary design for the seasteading community. (c) the artists. 


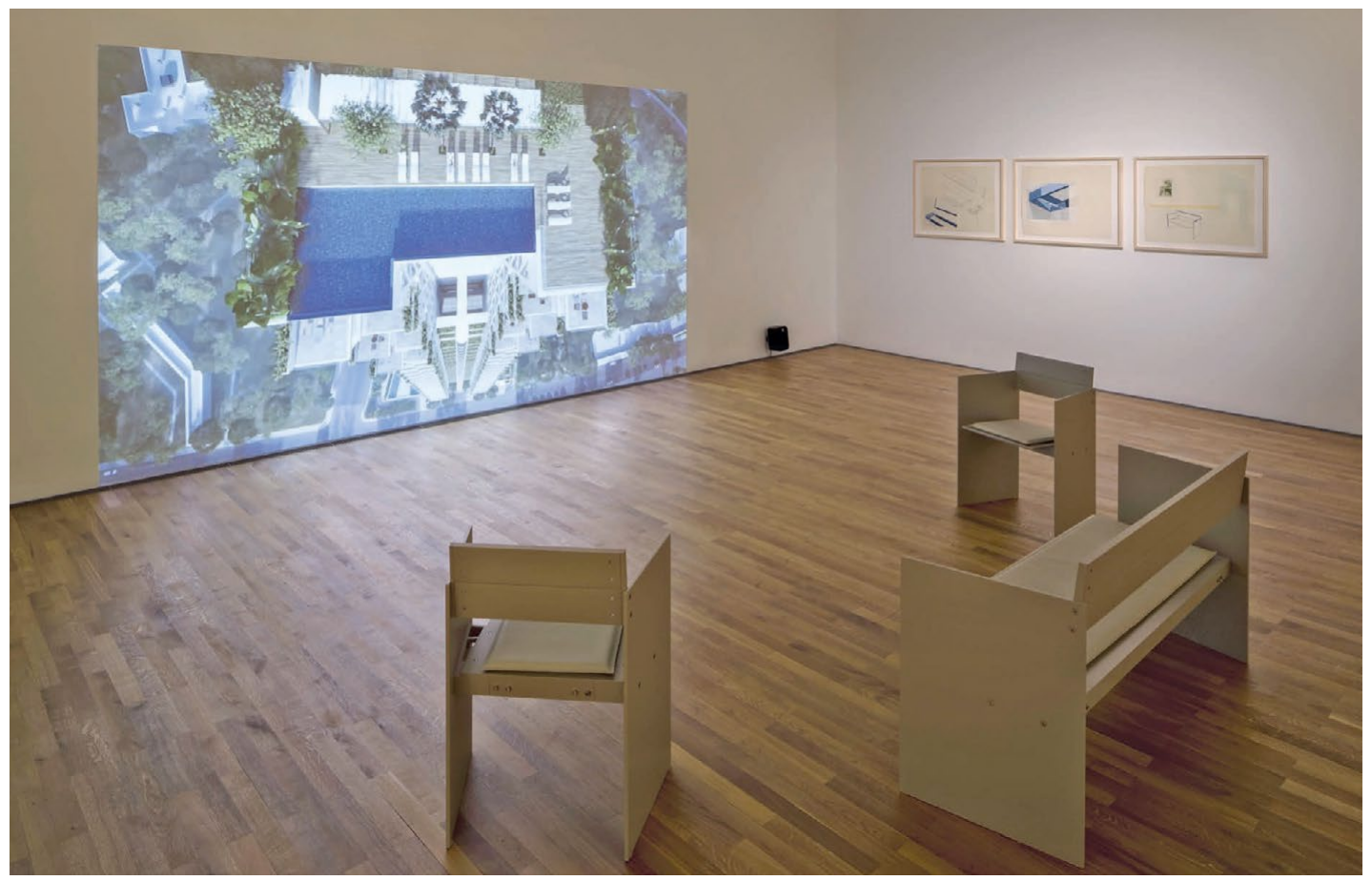

Figure 9. Christopher Kulendran Thomas, 60 Million Americans Can't Be Wrong (2017, 24 min.). In collaboration with Annika Kuhlmann. Includes prototypes for modular seating after Manmahal (மண்மகள்), designed by NEW TENDENCY in aluminum, leather; and studies for modular seating after Manmahal (மண்மகள்) in collaboration with NEW TENDENCY in watercolour, gouache, and coloured pencil on paper. (c) the artists.

Summit, a kind of parliament for stateless organisations. Since then, the congress has taken place several times at different locations. Some of the participating organisations operate outside political systems and are therefore regarded as terrorist organisations. Besides the temporary parliaments, there are also long-term projects, such as the construction of an autonomous parliament in Rojava (Northern Syria), which is to become a permanent institution (Figure 10). In this context, Staal investigates the concept of stateless democracy and its emancipatory potential. The Kurdish revolutionary movement, for instance, is decidedly critical of the role of the state: "The state is not so much something that represents independence or sovereignty, but something that reproduces an imperialist dependency" (Staal 2021). Thus, Staal wonders:

Can the nation state as we know it, as an overlapping understanding of territory and nation and a structure of governance, can this truly address the planetary crisis that we are now facing? The intersection of political, economic, humanitarian, ecological crisis? The work, in this case specifically of the Kurdish revolutionary movement, opens pathways to start thinking of forms of collective self-governance that certainly have social contracts, that do not deny the needs of equivalent forms of constitutions (ibid).
These demands call very specifically for self-governing structures that act locally and regionally and transcend the borders of nation states:

A great challenge in rethinking or reimagining the need for transnational forms of politics, planetary forms of politics, forms of politics that stretch our social contracts beyond the limitations of the nation state, is to think of how not to fall into the trap of the globalist idea that reproduces homogenous culture, that aims to reproduce the same form of capitalist democracy across the globe (ibid).

The examination of borders and demarcations is a fundamental undertaking as it questions the very essence of the state and propagates new forms of coexistence.

\section{About the exhibit}

\section{Beyond States. The Boundaries of Statehood}

$05.02 .2021-07.11 .2021$

Curators: Dr. Claudia Emmert, director, Ina Neddermeyer, head, and Caroline Wind, research assistant of the art department at the Zeppelin Museum, Jürgen Bleibler, head, and Felix Banzhaf, research assistant at the scientific department at the Zeppelin Museum. 


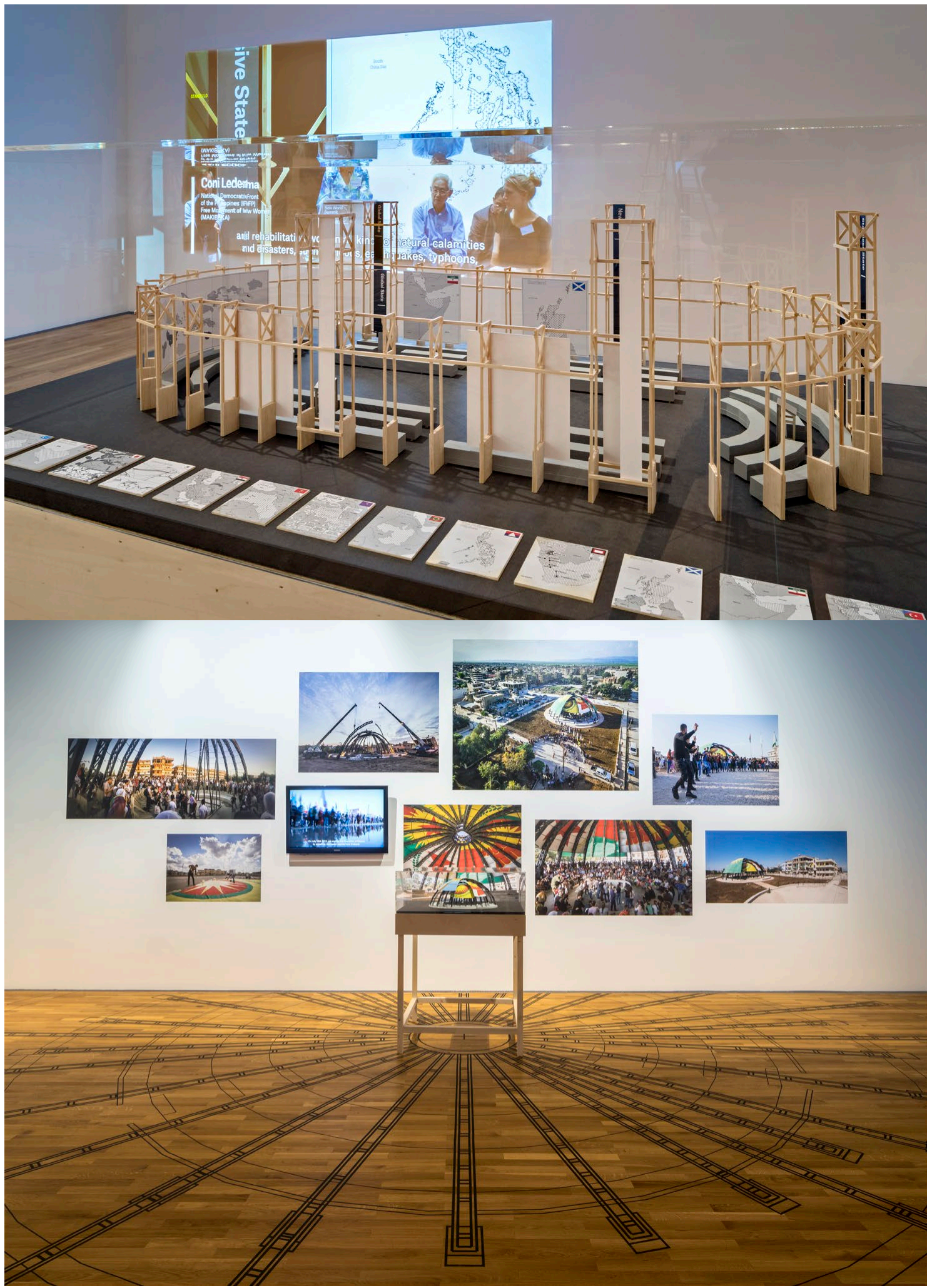

Figure 10. Jonas Staal, New World Summit-Rojava (2015-2018, video, 3 min). Architectural Model, Floorprint, Wall Collage, Zeppelin Museum, Foto Tretter. The New World Summit-Rojava consists of two parts: a commission by the autonomous government of Rojava (northern Syria) to design and construct a new public parliament and an international summit in the region. 
Invited artists: Nevin Aladağ, James Bridle, Simon Denny, Vera Drebusch \& Florian Egermann, Forensic Oceanography/ Forensic Architecture, Jacob HurwitzGoodman \& Daniel Keller, Peng! Kollektiv, Christophetr Kulendran Thomas, Henrike Naumann, Jonas Staal.

Zeppelin Museum Friedrichshafen

Director: Dr. Claudia Emmert

Seestr. 22

88045 Friedrichshafen

www.zeppelin-museum.de

PRESS ZEPPELIN MUSEUM

Simone Lipski +49 (0) 7541 - 380121

lipski@zeppelin-museum.de

\section{Works Cited}

de Syon, Guillamue. 2001. "Zwischen Hightech und Kavallerie. Der Lunéville-Zwischenfall von April 1913" in Wolfgang Meighörner (eds.), Zeppelin Museum Friedrichshafen. Wissenschaftliches Jahrbuch, Friedrichshafen.

Dominik Gerst, Maria Klessmann, and Hannes Krämer (eds.). 2021. Grenzforschung: Handbuch für Wissenschaft und Studium. Baden-Baden.

Haude, Rüdiger. 2014. "Überwältigend. Zur politischen Bedeutung der Schweizfahrt des LZ 4 am 1. Juli 1908" in Ursula Zeller et al. (eds.), Zeppelin Museum Friedrichshafen.
Wissenschaftliches Jahrbuch Band 11, Friedrichshafen.

Heller, Charles. 2021. "Online Assembly: Beyond BordersScreening 'Mare Clausum' and Charles Heller Artist Talk" Youtube, Zeppelin Museum Friedrichshafen, 1:29:24 (accessed 17 March 2021) https://www.youtube.com/ watch?v=7XsDOClcJTI

Monroy, Matthias. 2021. "Frontex Files: Der Militärischgrenzpolizeiliche Komplex" Netzpolitik (accessed 17 March 2021). https://netzpolitik.org/2021/frontex-filesder-militaerisch-grenzpolizeiliche-komplex/

Otto, Dietrich W. 2017. "Die Entwicklung der Regulierung der Luftfahrt in Hinsicht auf die Globalisierung 1783-1947" Zurich. Basel, Geneva.

Pötzsch, Holger. 2021. "Grenzen und Technologie" in Dominik Gerst, Maria Klessmann, Hannes Krämer (eds.), Grenzforschung: Handbuch für Wissenschaft und Studium. Baden-Baden.

Stall, Jonas. 2021. “Online Assembly: Beyond Borders-Artist Lecture \& Talk: Jonas Staal” Youtube. Zeppelin Museum Friedrichshafen, 1:17:23 (accessed 17 March 2021). https:// www.youtube.com/watch?v=PQ2p-OQUiRA\&t=1s

Zeising, Jeannine. 1998. "Reich und Volk für Zeppelin! Die journalistische Vermarktung einer technologischen Entwicklung" in Wolfgang Meighörner (eds.), Zeppelin Museum Friedrichshafen. Wissenschaftliches Jahrbuch, Friedrichshafen. 


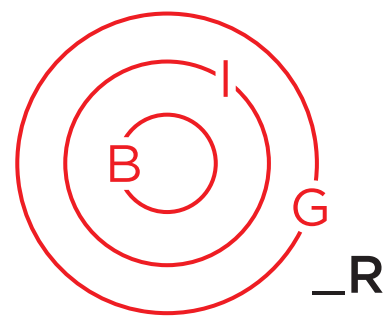

ART \& BORDERS

In English En français

\section{Outline \& Depth of Otherness: An Interview with Randa Maroufi}

\section{Contour et profondeur de l'altérité : Un entretien avec Randa Maroufi}

\section{Elisa Ganivet *}

In this interview, as part of the special section Art \& Borders, Art Editor Elisa Ganivet talks with the artist Randa Maroufi. The shore between Morocco and Europe is particularly questioned, along with Maroufi's fine work around the more structural, societal and gender boundaries. Her research is synthesized by stagings where a strong and clearsighted image predominates.

Dans cet entretien réalisé pour la section spéciale Art \& Borders, notre rédactrice Elisa Ganivet s'entretient ici avec l'artiste Randa Maroufi. La rive entre le Maroc et l'Europe est particulièrement questionnée. Tout comme l'est son fin travail tourné autour des frontières plus structurelles, sociétales et de genres. Ses recherches sont synthétisées par des mises en scène où prédomine une image forte et clairvoyante.

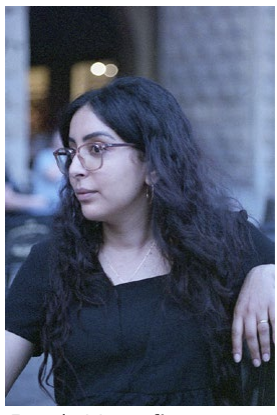

Randa Maroufi

www.randamaroufi.com

\section{About the artist}

Born in 1987 in Casablanca, Randa Maroufi currently lives and works in Paris. She is a graduate of the National Institute of Fine Arts, Tetouan, Morocco (2010) and the School of Fine Arts, Angers, France (2013). She also earned a diploma from Le Fresnoy Studio National des Arts Contemporains, Tourcoing, France (2015) and was an Artist Member of Academy of France in Madrid at Casa de Velázquez in 2017-2018.

Belonging to the generation that grew up in an era dominated by image, she collects them with as much eagerness as suspicion, and ceaselessly questions their veracity. She prefers to put her ambiguous fictions in the service of reality, and the field of her experimentation encompasses the occupation of public space and gender issues, of which she highlights the founding mechanisms.

Her work has been shown at art galleries and festivals around the world, and she has received many awards for her film Le Park (2015), and Bab Sebta (2019).

\section{A propos de l'artiste}

Née en 1987 à Casablanca, Randa Maroufi vit et travaille à Paris. Elle est diplômée de l'Institut National des Beaux-Arts de Tétouan, Maroc (2010), de l'École Supérieure des Beaux-Arts d'Angers, France (2013) ainsi que du Fresnoy - Studio National des Arts Contemporains, Tourcoing, France (2015). Randa Maroufi était membre artiste de l'Académie de France à Madrid - la Casa de Velázquez en 2017-2018.

Randa Maroufi s'intéresse à la mise en scène des corps dans l'espace public ou intime. Une démarche souvent politique, qui revendique l'ambiguité pour questionner le statut des images et les limites de la représentation.

Ses expositions récentes ont été présentées dans des galeries d'art et des festivals du monde entier, et elle a reçu de nombreux prix pour son film Le Park (2015) et Bab Sebta (2019).

\footnotetext{
* Elisa Ganivet, doctor of philosophy, art historian, author of Border Wall Aesthetics (Columbia University Press 2020), has worked as a cultural manager and curator for international public and private cultural organizations. Web: www.ElisaGanivet.com
} 
Elisa Ganivet: Randa, I have the feeling that the starting point of your aesthetic corpus was the positioning of the woman for structure and organic inquiry in society (with your performance Attempt of Seduction, 2013 and your installation Close Up, 2016), and that you naturally considered the place of the woman in the public space. In your photographic series Reconstitutions, 2016, the freeze-frames of scene before harassment and/or sexual tension are obvious and disturbing. These images may seem familiar and are, to say the least, revolting in what they imply as potential targets and underlying contempt.

With your photographic series and video Les intruses (The intruders), 2018-2019, you thwart the male mirror where women take possession of the street to simply make life, wait, or commit some mischief. This reversal of gender makes women visible in places where they are generally absent (cafés, fast-food, street corners, metro stations, or with traditinal male gestures, etc.), and it highlights idleness as well as petty activity (a theme also covered in The Park, 2015)

This artistic approach blurs the dichotomous male/female border. In the documentary and poetic look of the film The Great Safae, 2014, which evokes the transsexual housekeeper who worked in your family in Morocco-you take back this benevolence outside of any prejudice, outside of the hchouma, a notion between shame and modesty that is legion in traditional society. It seems to me that the analysis of these borders, first intimate and then societal, as well as your double experience in France and Morocco, naturally led you to an interest in a more geopolitical border. The one located in the enclave of Ceuta is symptomatic and you develop the related problems.

With the Around the Gate series, 2018 [Figure 1], we discover Bab Sebta exceptionally empty because the photographs were taken on a public holiday. Through the perspective of the volumes and the tones, the border zone is like a mirage, or even a set for a future dramatic film with the view of a few migrants who try to cross it in the backlight.

You propose another original reading thanks to the blue series of cyanotypes Diwana, 2018-2020. Here it is on the map that the customs are read with a psychogeographic application of the smugglers. They are the first to feel the territory they cross daily. This path is the reason for their financial survival. The meticulous details are captioned to facilitate our understanding. The cyanotype, photosensitive solution process, confers a preciousness that is justified by the risk they take.
Elisa Ganivet : Randa, j'ai l'impression que le point de départ de ton corpus esthétique avait pour pivot le positionnement de la femme, comme structure et questionnement organique dans la société (avec ta performance Attempt of seduction, 2013 et ton installation Close up, 2016) et que tu as naturellement considéré la place de la femme dans l'espace public. Dans ta série photographique Reconstitutions, 2016, les arrêts sur images de scène avant harcèlement et/ou tensions sexuelles sont manifestes et troublants. Ces images peuvent nous sembler familières et sont pour le moins révoltantes dans ce qu'elles supposent comme cibles potentielles et de mépris sous-jacent.

Avec ta série photographie et vidéo Les Intruses, 2018-2019, tu déjoues le miroir masculin où les femmes prennent possession de la rue pour simplement faire vie, attendre ou commettre quelques méfaits. Ce renversement des genres rend visible la femme là où elle est généralement absente (cafés, fast-foods, angles de rues, stations de métro, avec une gestuelle particulière etc.), et il met en exergue le désœuvrement tout comme le petit trafic (thématique également abordée dans Le Park, 2015).

Cette démarche artistique floute la frontière dichotomique homme/ femme. Dans le regard documentaire et poétique du film La Grande Safae, 2014, cette aide-ménagère transsexuelle qui exerça dans ta famille au Maroc, tu reprends cette bienveillance en dehors de tout préjugé, hors du "hchouma", notion entre honte et pudeur qui fait légion dans la société traditionnelle. II me semble que l'analyse de ces frontières d'abord intimes puis sociétales ainsi que ton expérience double en France et au Maroc t'ont naturellement conduites à t'intéresser à une frontière plus géopolitique. Celle située à l'enclave de Ceuta est symptomatique et tu en développes les problématiques afférentes.

Avec la série Around the gate, 2018 [Figure 1] on découvre Bab Sebta exceptionnellement vide car les photographies ont été prises un jour férié. Par la perspective des volumes et les tonalités, la zone frontalière s'apparente à un mirage, voire un décor pour un prochain film dramatique avec en contre-jour, la vue de quelques migrants qui tâchent de la franchir.

Tu proposes une autre lecture originale grâce à la série bleue des cyanotypes Diwana, 2018-2020. Ici c'est sur plan que la douane est lue avec une application psychogéographique des contrebandiers. Ces derniers sont les premiers à ressentir le territoire qu'ils traversent au quotidien. Ce trajet est la raison de leur survie financière. Les détails méticuleux sont légendés pour nous en faciliter la compréhension. Le cyanotype, procédé de solution photosensible, confère une préciosité justifiée par le risque qu'ils encourent.

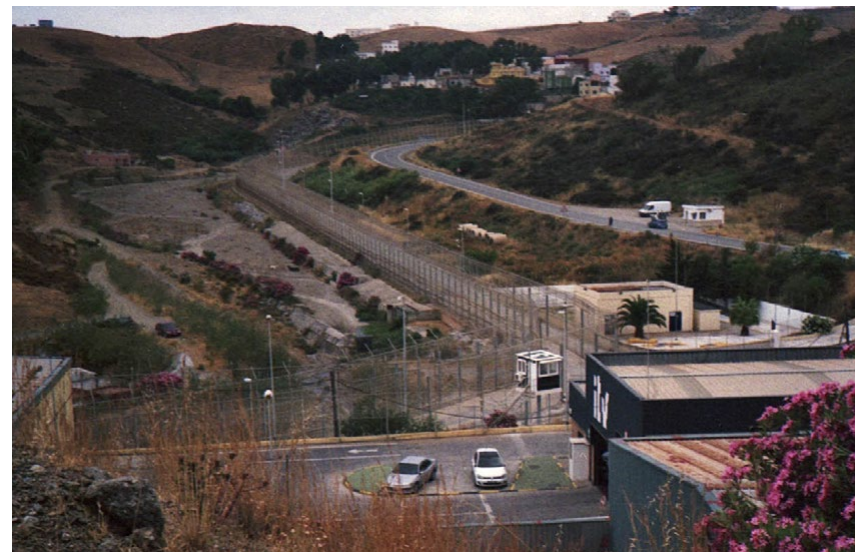

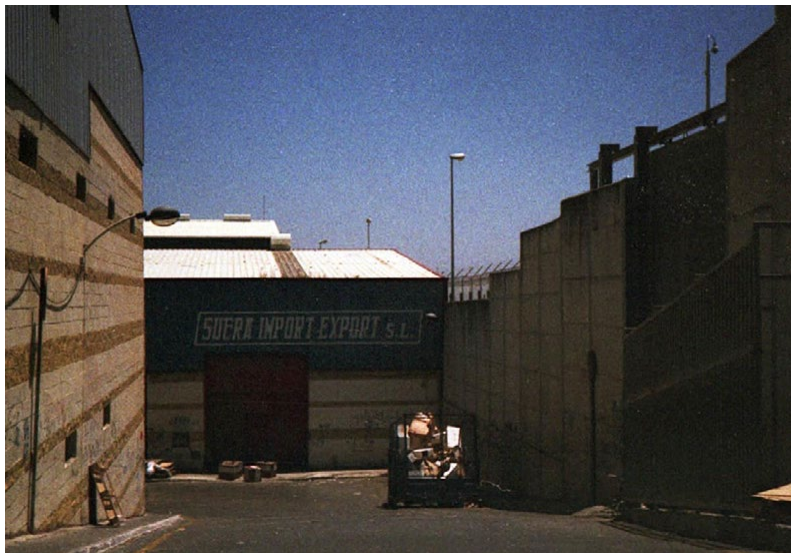

Figure 1. Excerpts from Around the Gate, 2019 (photo series). Prints on cotton paper, 308 grams, American box @ Randa Maroufi. 
Borders in Globalization Review | Volume 3 | Issue 1 | Fall/Winter 2021

Ganivet, "Outline \& Depth of Otherness: An Interview with Randa Maroufi"
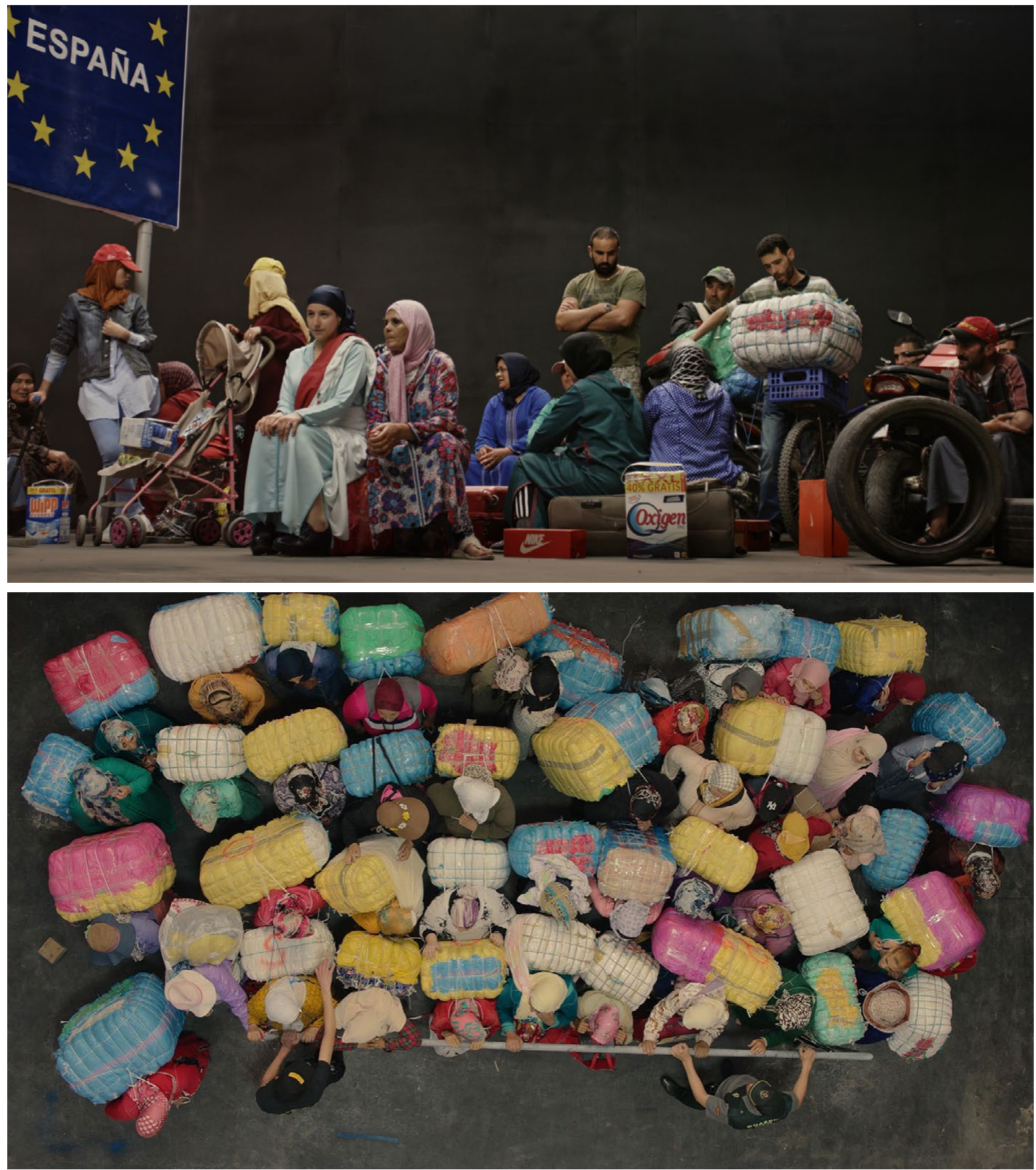

Figure 2. Excerpts from Bab Sebta, 2019. Short film, 19'. Production: Barney Production \& Montfleuri Production. With the support of: Fondation des Artistes, Doha Film Institute, CNC, Arab Fund for Arts and Culture, Casa de Velázquez, Le Fresnoy.

In the magnificent 2019 film Bab Sebta (Ceuta's Gate) [Figure 2], you focus on the activity of this border zone by putting in scene the main protagonists: smugglers, bi-national border police, customs officers. There is no denunciation, only a factual statement. The setting is gray, neutral, but the ground markings indicate strategic locations (tourist corridor, police stations, stopping zones, signs, etc.). They are complemented by equipment (cars, barriers, etc.). The flow of people is understood by slow dollies on the characters and by $180^{\circ}$ low angle views (by the way, do you know Alejandro Cartagena's 2014 Carpoolers series? ). In your film, we see in particular the mutual aid between the smugglers who ingeniously pack their colorful bundles well tied on their backs or hidden under their clothes. Voice-overs guide us, with first of all a policewoman of the Spanish border admitting herself that the choreography
Dans le magnifique film Bab Sebta, 2019 [Figure 2] tu t'attardes tout particulièrement à l'activité de cette zone frontalière en mettant en scène les principaux protagonistes: contrebandiers, police binationale de la frontière, douaniers. II n'y a aucune dénonciation simplement une énonciation factuelle. Le décor est gris, neutre, mais le marquage au sol signale les emplacements stratégiques (corridor des touristes, postes de police, zones d'arrêt, panneaux, etc.). Ils sont complétés par des équipements (voitures, barrières, etc.). Le flux des personnes se comprend par des lents travellings sur les personnages et par des vues en contreplongées à $180^{\circ}$ (à ce propos connais-tu la série Carpoolers, 2014 d'Alejandro Cartagena ?). Dans ton film, on voit en particulier l'entraide entre les contrebandières qui empaquettent ingénieusement leurs ballots colorés bien ficelés sur leurs dos ou cachés sous leurs vêtements. Des voix-off nous guident, avec tout d'abord une policière de la frontière espagnole avouant elle-même que la chorégraphie de 
of this zone is quite complex. How do you perceive this zone? Was the purpose of this project to untangle the threads?

Randa Maroufi: The sharing of public space is a common thread in my work, which I approach through actions or films. However, I try not to limit myself to one subject or medium. I often have a main idea, and related ideas which come to graft. Moreover, ambiguity is part of the means with which I play, both in The Great Safae or for Bab Sebta.

There is a porous border between documentary and fiction in my film productions, and this is also what allows me to take another look at my concerns, which are often social, societal and political. Indeed it also allows me to highlight the complexity of these issues; because the intimate and the social are very often linked, and they cohabit in most of my projects, both in the conception (the group work with the inhabitants/ actors of the spaces I study), and in the finished work. I try to have an approach which is situated between the reportage, the cinema and the sociological study.

This is particularly true in the Bab Sebta project, where the question of the border is at the heart of the subject, and for which several of my productions offer a view that is both universal and very intimate, as in Diwana, 2018-2019 [Figure 3], where drawings of the border are executed from memory by people who live there every day. In the film too, where the sequence shots, the travelling and the zenithal shots help me to play with the look and the point of view.

And I didn't know Alejandro Cartagena's work, I just discovered it in real life at Paris Photo and I find it very interesting! cette zone est bien complexe. Comment perçois-tu cette zone ? Ce projet avait-il pour dessein d'en démêler les fils?

Randa Maroufi : Le partage de l'espace public est un fil conducteur de mon travail, que j'appréhende via des actions ou des films. J'essaie cependant de ne pas me limiter à un propos ou à un médium. J'ai souvent une idée principale, et des idées connexes qui viennent se greffer. Par ailleurs, l'ambiguité fait partie des moyens avec lesquels je joue, à la fois dans La grande Safae ou pour Bab Sebta.

Il y a une frontière poreuse entre le documentaire et la fiction dans mes productions filmiques, et c'est aussi ce qui me permet de poser un autre regard sur mes préoccupations qui sont souvent d'ordre social, sociétal et politique. Cela me permet aussi de mettre en évidence la complexité de ces problématiques en effet car l'intime et le social sont très souvent liés, et ils cohabitent dans la plupart de mes projets, tant dans la conception (le travail de groupe avec les habitant.e.s/acteur.rice.s des espaces que j'étudie) que dans l'œuvre finie. Je tente d'avoir une approche qui se situe entre le reportage, le cinéma et l'étude sociologique.

C'est d'ailleurs ce que l'on retrouve particulièrement dans le projet Bab Sebta où la question de la frontière est au cœur du sujet, et pour laquelle plusieurs de mes productions proposent un regard à la fois universel et très intime, comme dans Diwana [Figure 3] où il s'agit de dessins de la frontière exécutés de mémoire par des personnes qui l'habitent au quotidien. Dans le film aussi, où les plans-séquences, les travellings et les plans zénithaux m'aident à jouer avec le regard et le point de vue.

Et je ne connaissais pas le travail d'Alejandro Cartagena, je viens de le découvrir en vrai à Paris photo et je le trouve très intéressant !

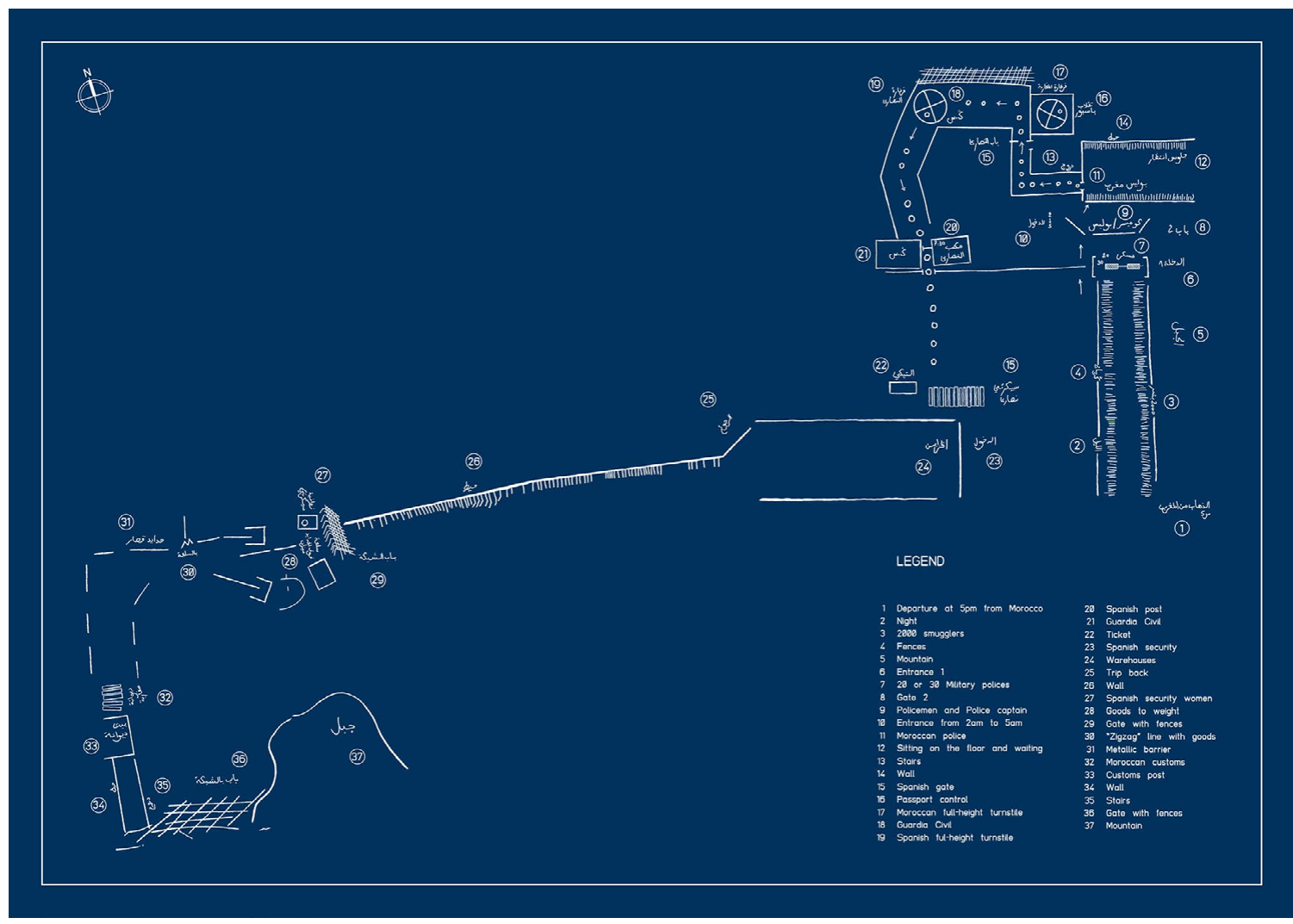

Figure 3. "Sans titre 5" from Diwana, 2018-2019 (series of cyanotype). Cyanotype on Velin d'Arches, 100 x 135.5 cm ( Randa Maroufi. 
EG: By the way, what was your reaction when last spring King Mohammed VI left the floodgates open at the border between Morocco and Spain? Was this really a means of pressure and a response to the medical aid granted to Brahim Ghali, dissident leader of the Polisario Front by Spain? The images were at least impressive.

RM: The migration issue is very complex, and in this event, the blame lies on both sides. Morocco has considered Sebta as an extension of Moroccan territory, but we are not fooled. It is mainly to put pressure on Europe and in this case on Spain, to the detriment of the inhabitants of Sebta who are part of the Moroccan people. Morocco could have taken a more intelligent and respectful approach, for example by putting pressure on the economy. On the other hand, Spain and Europe are playing on this situation by turning a blind eye to these issues and blaming Morocco for letting the people migrate to Europe and neglecting their protection. Certainly, Morocco has not acted well, but Europe is using this event to cover up its own abuses against migrant populations, which proves, as sociologist Mehdi Alioua (Associate Professor at the International University of Rabat, attached to "Sciences Po Rabat") reminds us, that this is not a migration crisis but a political crisis.

EG: Yes, thank you for mentioning here Professor Alioua, a specialist in the study of transnational and cross-border migratory movements between West Africa, the Maghreb and Europe.

Randa, in your work Bab Sebta, you reveal the exceptional figures of the women smugglers. They are visually stunning and were recently displayed all over Paris with posters for the exhibition "Zone Franche " at the $\mathrm{ICl}$, and you extend these images with the series of portraits Nabila \& Keltoum \& Khadija, 2015 [Figure 4]. How were you able to approach and convince all these workers to participate in your film? Do you have maybe any anecdotes to share with us?

RM: My projects are the result of discussions, interviews and meetings. Affinities and dialogues are created, and certain people quickly take an active part in the production. It's a team work that is set up in a rather organic way. For Bab Sebta, Nabila and Keltoum were essential to the project, and they guided me in the field and during my location scouting. For example, they recruited women to play smugglers without telling me that this was not their real activity, thinking that it would be a problem. I overheard them (later while I was logging the film) telling them the right things to do by whispering "to make it real". I found this funny but above all very interesting because it shows the women heads that they are, the importance that they had for the realization of the film on the one hand, and it confirmed to me on the other hand that the question of the ambiguity of the staging works.

EG: Similarly, you pay tribute to your father who was a customs inspector. Does the genesis of this project come from some childhood memories? Is this a triggering factor?

RM: My work around the border obviously touches on a part of my personal history, but to a degree that I want to control. I also grew up in the "world" of the frontier and several members of my family have worked there in some capacity. Some of my father's objects have inspired me to create works of art, such as the blue customs cloth that belonged to my father for the video Les plieurs (The Folders), 2021 [Figure 5], or the customs register that was a pivotal point in my thinking for the exhibition "L'autre comme hôte" (The Other as Host) at the Centre d'Art Contemporain Chanot in Clamart
EG : D'ailleurs quelle fut ta réaction lorsqu'au printemps dernier, le roi Mohammed VI a laissé les vannes ouvertes à la frontière entre le Maroc et l'Espagne ? S'agissait-il vraiment d'un moyen de pression et d'une réponse envers l'aide médicalisée octroyée à Brahim Ghali, chef dissident du front polisario par l'Espagne ? Les images étaient tout du moins impressionnantes.

RM : La question migratoire est très complexe, et dans cet évènement, le blâme se situe des deux côtés. Le Maroc a considéré Sebta comme une extension du territoire marocain, mais nous ne sommes pas dupes. C'est surtout pour faire pression sur l'Europe et en l'occurrence sur l'Espagne, au détriment des habitant.e.s de Sebta qui font partie du peuple marocain. Le Maroc pouvait engager une démarche plus intelligente et respectueuse, en faisant pression sur l'économie par exemple. De l'autre côté, l'Espagne et l'Europe jouent de cette situation en fermant les yeux sur ces questions et en remettant la faute sur le Maroc pour avoir laissé les populations migrer vers l'Europe, et avoir négligé leur protection. Certes, le Maroc n'a pas bien agi, mais l'Europe utilise cet évènement pour maquiller ses propres exactions envers les populations migrantes, ce qui prouve bien, comme le rappelle le sociologue Mehdi Alioua (Professeur Associé de I'Université Internationale de Rabat, rattaché à « Sciences Po Rabat »), qu'il ne s'agit pas d'une crise migratoire mais d'une crise politique.

EG : Oui, merci d'évoquer ici le Professeur Alioua, spécialiste de l'étude des mouvements migratoires transnationaux et transfrontaliers entre l'Afrique de l'Ouest, le Maghreb et l'Europe.

Randa, dans ton œuvre Bab Sebta, tu révèles les figures exceptionnelles des contrebandières. Elles sont visuellement magnifiques et ont été récemment placardées dans tout Paris (affiches de l'exposition "Zone Franche » à l'ICl et tu prolonges ces images avec la série de portraits Nabila \& Keltoum \& Khadija, 2015 [Figure 4]. Comment as-tu pu approcher tous ces travailleurs et les convaincre de participer à ton film?

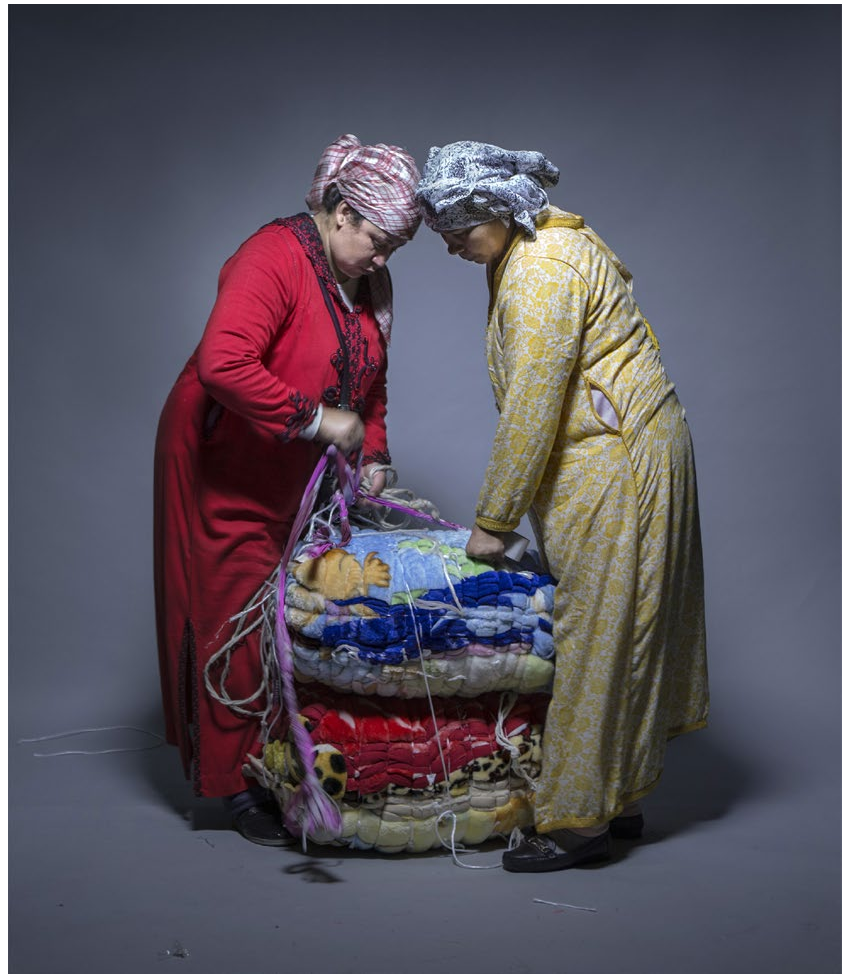

Figure 4. "Préparation" from Nabila \& Keltoum \& Khadija, 2015 (photo series). Colour Photography, (c) Randa Maroufi. 


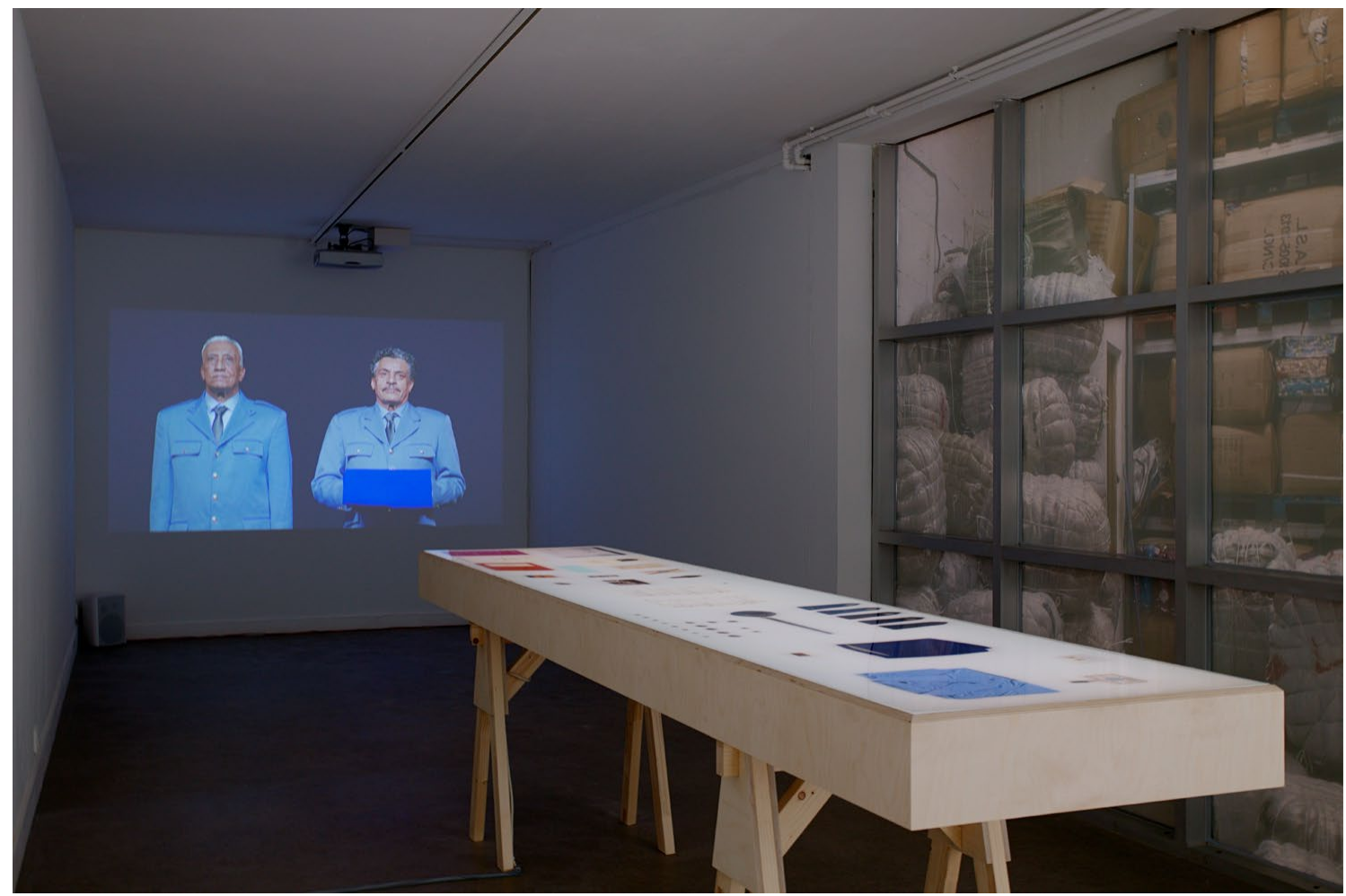

Figure 5. Les plieurs, 2021. Video, 9'. Coproduced by CACC Clamart ( Randa Maroufi. View of the exhibition 'l'autre comme hôte' by Randa Maroufi at CACC Clamart @ Tony Trichanh.

EG: Today, does your binational experience give you insight into the contradictions of each of these countries? There was a time when people talked a lot about cultural identity, what does this term inspire to you, is it still appropriate?

RM: The question of a "cultural identity" doesn't mean much, even less now. There is no dual experience but a common experience, histories and personal identities. It is from these shared experiences that I come to see more clearly what I am studying. Clarity rather than insight. It comes from my research and fieldwork, from dialogues and interviews with those who become the actors of my films.

I don't do politics, but my work has a political dimension. It is for me to pose and propose a glance on a social and political reality. It is not a question either of entering a frontal militant fight but of transmitting my vision in a soft and intelligent way, by playing with the codes, by diverting situations.

EG: Speaking of codes, how did the Stand-by Office, 2017 [Figure 6] project come about? Here, migrants living in Amsterdam cannot work but they have taken over an office. The absurdity of this inability to work is visually reproduced. We come back to the impossibility of integration, a discourse that monopolizes the discourse of Western societies. Could you explain your approach to us?

RM: I was on an art residency in Amsterdam. I was walking through the streets of the city and I noticed the words "We Are Here" on the surface of a building. I immediately thought it was a festive event, and then I saw Osman and Ahmed standing in front of it. I asked them what was going on here and they told me that they were part of a group of refugees living in empty buildings in the suburbs of Amsterdam. They invited me to discover the place, old disused
RM : Mes projets sont le fruit de discussions, d'entretiens et de rencontres. II se crée alors des affinités, des dialogues, et certaines personnes prennent vite une part active dans la production. C'est un travail en équipe qui se met en place de manière plutôt organique. Pour Bab Sebta, Nabila et Keltoum ont été essentielles au projet, et elles m'ont guidé sur le terrain et pendant mes repérages. Elles ont, par exemple, recruté des femmes pour jouer des contrebandières sans me dire que ce n'était pas leur activité réelle, pensant que ce serait un problème. Je les ai entendues (plus tard en dérushant le film) leur indiquer les bons gestes à avoir en chuchotant « pour faire vrai ». J'ai trouvé cela drôle mais surtout très intéressant parce que cela montre les femmes de têtes qu'elles sont, l'importance qu'elles ont eue pour la réalisation du film d'une part, et cela m'a confirmé, d'autre part, que la question de l'ambiguité de la mise en scène fonctionne.

EG : Pareillement, tu rends hommage à ton père qui était inspecteur des douanes. La genèse de ce projet viendrait-il de certains souvenirs d'enfance ? Est-ce là un fondement déclencheur ?

RM : Mon travail autour de la frontière touche évidemment à une part de mon histoire personnelle, mais à un degré que je souhaite maîtriser. J'ai par ailleurs grandi dans "l'univers" de la frontière et plusieurs membres de ma famille y ont travaillé de près ou de loin. Certains objets de mon père m'ont inspiré des œuvres, comme le tissu bleu de la douane qui appartenait à mon père pour la vidéo Les plieurs, 2021 [Figure 5] ou le registre de la douane qui a été un pivot dans ma réflexion pour l'exposition "L'autre comme hôte » au Centre d'Art Contemporain Chanot à Clamart.

EG : Aujourd'hui, ton expérience binationale t'apporte-t-elle une clairvoyance sur les contradictions propres à chacun de ces 

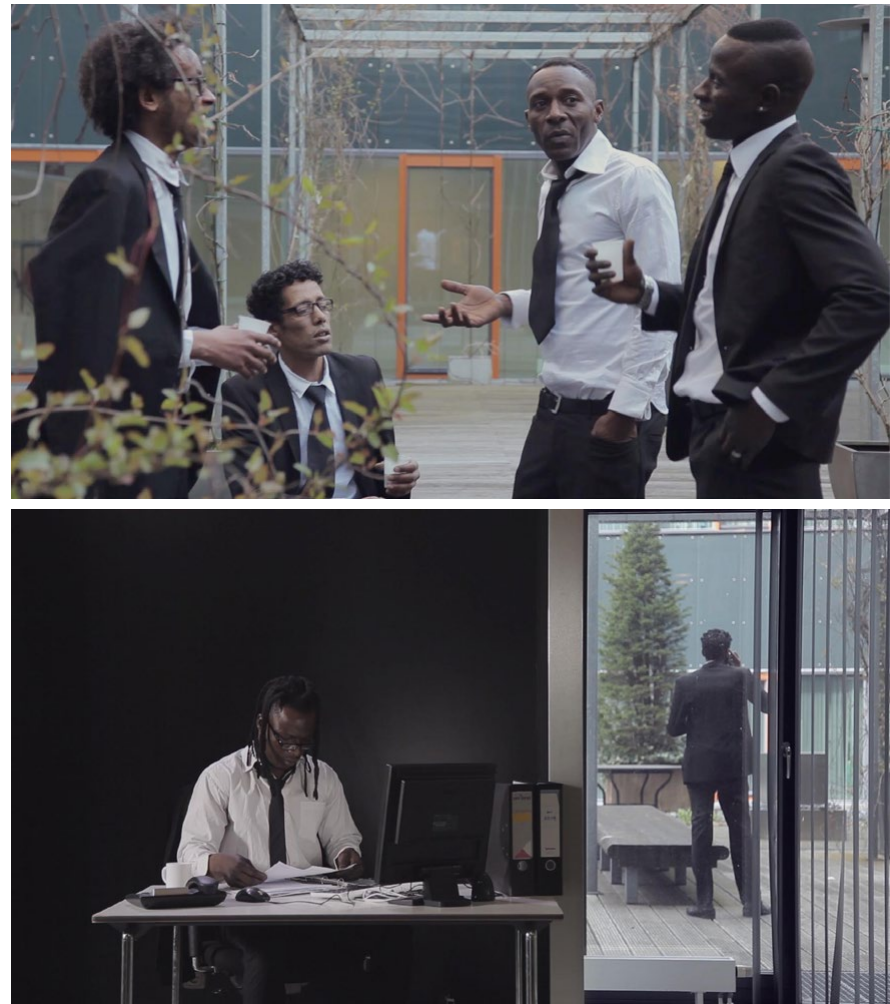

Figure 6. Stand-by Office, 2017. Video, 13'20'. In collaboration with the "We Are Here » group, Amsterdam. With the support of: Le Fresnoy, Culture Resource's Production Awards Program, CBK Zuidoost, Cinelabs Romania, Studio aux cuves dorées. (c) Randa Maroufi.

offices dating from the early 2000 s, serving as their living space. And yes, it is this contrast that struck me; and I wanted to create from this a fiction mixing personal history and history of the place.

I went back there every day for two months, to discuss, cook, play cards, and listen to music but mostly to kill time, I showed them my work and we thought together about what we could do with this place. They felt involved and, as is often the case, the bonds of trust were forged naturally, so we formed a working team. I also leave a lot of room for improvisation: this also plays a role in the fiction/documentary ambiguity.

The film works on the way refugees are represented and the role they are given. We see the person as a "migrant" first, we see the difficulties of life. We are presented with political measures rather than individual realities, with speeches that are locked into something alarmist.

As far as the impossibility of integration is concerned, it is the opposite that I am trying to show. The suit and tie is a western code, which implicitly justifies a legal status, a certain authority. Stand-by Office is in this sense a wink, and reverses the imaginary that serves as official history, to reveal an implicit reality and little shown.

EG: And what is the project Fragments d'un territoire (Fragments of a territory), 2020?

RM: It's a performance project where I wanted to reactivate elements used (costumes, sets, props, etc.) in the film Bab Sebta and with hindsight, I realize that it was more a response to a need to experiment in situ. pays ? II fut un temps, on parlait beaucoup d'identité culturelle, qu'est-ce que t'inspire ce terme, est-il encore approprié ?

RM : La question d'une "identité culturelle " ne veut pas dire grand-chose, encore moins à l'heure actuelle. II n'y a pas d'expérience double mais une expérience commune, des histoires et des identités personnelles. C'est à partir de ces expériences à plusieurs que je parviens à voir plus clairement l'objet que j'étudie. Clarté plutôt que clairvoyance. Elle me vient de mes recherches et de mes prospections de terrain, des dialogues et des entretiens avec ceux et celles qui deviennent les acteur.rice.s de mes films.

Je ne fais pas de la politique, mais mon travail a une dimension politique. II s'agit pour moi de poser et de proposer un regard sur une réalité sociale et politique. II n'est pas non plus question d'entrer dans un combat militant frontal mais de transmettre ma vision de manière douce et intelligente, en jouant avec les codes, en détournant des situations.

EG : En parlant de codes, comment a surgi le projet Stand-by Office, 2017 ? [Figure 6] Ici des migrants installés à Amsterdam ne peuvent travailler mais ils ont investi un bureau. L'absurdité de cet empêchement à travailler est visuellement reprise. On en revient à l'impossibilité de l'intégration, discours qui monopolise le discours des sociétés occidentales. Pourrais-tu nous expliquer ta démarche?

RM : J'étais en résidence artistique à Amsterdam. Je marchais dans les rues de la ville et j'ai remarqué la mention « We Are Here » sur la surface d'un bâtiment. J'ai tout de suite pensé à un événement festif, puis j'ai vu Osman et Ahmed postés devant. Je leur ai demandé ce qu'il se passait ici et ils m'ont répondu qu'ils faisaient partie d'un groupe de réfugiés installés dans des bâtisses vides en banlieue d'Amsterdam. Ils m'ont invité à découvrir le lieu, des anciens bureaux désaffectés datant du début des années 2000 , leur servant de lieu de vie. Et oui, c'est ce contraste qui m'a frappé ; et j'ai voulu créer à partir de ça une fiction mêlant histoire personnelle et histoire du lieu.

J'y suis retournée tous les jours pendant deux mois, pour discuter, cuisiner, jouer aux cartes, écouter de la musique mais surtout tuer le temps, je leur ai montré mon travail et nous avons pensé ensemble à ce qu'on pouvait faire de ce lieu. Ils se sont sentis impliqués et comme souvent, les liens de confiance se sont tissés naturellement, alors on a formé une équipe de travail. Je laisse aussi une grande place à l'improvisation : ça rentre aussi en compte dans l'ambiguité fiction/documentaire.

Le film travaille sur la manière dont les personnes réfugiées sont représentées et le rôle qu'on leur attribue. On voit d'abord la personne en tant que " migrante ", on voit les difficultés de vie. On nous présente plutôt des mesures politiques que des réalités individuelles, des discours qui s'enferment dans quelque chose d'alarmiste.

Pour ce qui est de l'impossibilité de l'intégration, c'est tout le contraire que je cherche à montrer. Le costume/cravate est un code occidental, qui implicitement justifie d'un statut légal, d'une certaine autorité. Stand-by Office est dans ce sens un clin d'œil, et inverse l'imaginaire qui fait office d'histoire officielle, pour dévoiler une réalité implicite et peu montrée. 
Borders in Globalization Review | Volume 3 | Issue 1 | Fall/Winter 2021

Ganivet, "Contour et profondeur de l'altérité : Un entretien avec Randa Maroufi"

EG: Are you still going to work on the theme of a more geopolitical border, of geostrategic stakes, and if so, which axis interests you more precisely? What have you learned from this field research?

RM: Why not. My projects cannot exist without my field research. So everything is to be learned.

EG: What is your current project?

RM: The project I am working on at the moment is called L'mina and is located in Morocco. It's a research project about an ex-mining city.

EG: Okay, so the immersion is in geological terrain, with social issues and economic and societal impacts around it. Thank you very much Randa for enlightening us on your fascinating work!
EG : Et qu'est-ce que le projet Fragments d'un territoire, 2020 ?

RM : C'est un projet de performance où je souhaitais réactiver des éléments utilisés (costumes, décors, accessoires, etc.) dans le film Bab Sebta et avec du recul, je me rends compte que ça répondait plutôt à un besoin d'expérimenter in situ.

EG : Vas-tu encore travailler sur la thématique d'une frontière plus géopolitique, d'enjeux géostratégiques, et si oui, quel est l'axe qui t'intéresse davantage ? Qu'as-tu appris de ces recherches de terrain?

RM : Pourquoi pas. Mes projets ne peuvent exister sans mes recherches de terrain. Tout est donc à apprendre.

EG : Quel est ton projet actuel ?

RM : Le projet sur lequel je travaille en ce moment s'intitule L'mina et se situe au Maroc. Il s'agit d'une recherche autour d'une ex-cité minière.

EG : D'accord, alors l'immersion est en terrain géologique, avec en pourtour les enjeux sociaux et les impacts économiques et sociétaux. Merci beaucoup Randa de nous avoir éclairés sur ton passionnant travail ! 


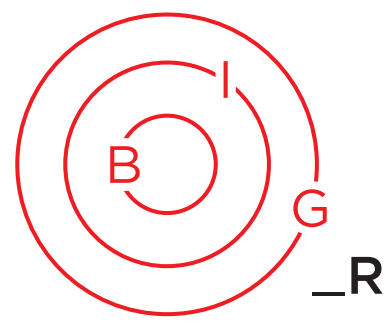

\section{ART \& BORDERS}

In English En français

\title{
On the Passage of Existence: An Interview with Taysir Batniji
}

\author{
Du passage de l'existence: \\ Un entretien avec Taysir Batniji
}

\section{Elisa Ganivet *}

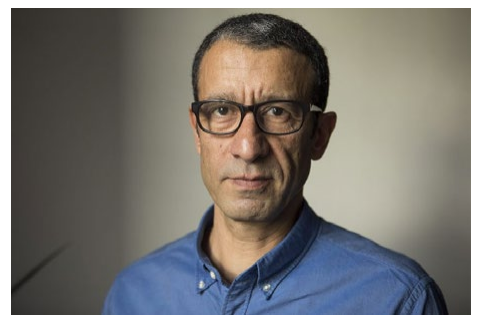

Taysir Batniji (photo credit : Sophie Jaulmes)

www.taysirbatniji.com
In this interview, as part of the special section Art \& Borders, Art Editor Elisa Ganivet talks with the artist Taysir Batniji. The occasion of his exhibition at the Macval (France) allowed reflection on some of his long-term works and on his life path. The strength of 'the idea' prevails over the medium for a sensitive awakening to the state of a world simultaneously foreign and familiar.

Dans cet entretien réalisé pour la section spéciale Art \& Borders, notre rédactrice Elisa Ganivet s'entretient ici avec l'artiste Taysir Batniji. Son exposition au Macval (France) revient sur des pièces phares au long cours ainsi que sur son parcours de vie. Dans son œuvre, la force de l'idée prévaut sur le médium pour un réveil sensible sur l'état d'un monde simultanément étranger et familier.

\section{About the artist}

Born in Gaza in 1966, Taysir Batniji studied art at Al-Najah University in Nablus, Palestine. In 1994, he was awarded a fellowship to study at the School of Fine Arts of Bourges in France. Since then, he has been dividing his time between France and Palestine. Between two countries and two cultures, Batniji has developed a multi-media practice, including drawing, installation, photography, video and performance.

Taysir Batniji's artwork, often tinged with impermanence and fragility, draw its inspiration from his subjective story, but also from current events and history. His methods distance, divert, stretch, conceptualize or simply play with the initial subject, offering, at the end, poetic, sometimes acrid, points of view on reality.

Taysir was awarded the Abraaj Group Art Prize in 2012 and became the recipient of the Immersion residency program, supported by Hermes Foundation, in alliance with Aperture Foundation in 2017. His works can be found in the collections of many prestigious institutions of which the Centre Pompidou and the FNAC in France, the V\&A and The Imperial War Museum in London, the Queensland Art Gallery in Australia and Zayed National Museum in Abu Dhabi.

\section{A propos de l'artiste}

Né à Gaza, Palestine, en 1966. Vit et travaille à Paris. Taysir Batniji a étudié l'art à l'université nationale An-Najah de Naplouse, avant de poursuivre des études en France à l'École nationale supérieure d'art de Bourges entre 1995 et 1997. Depuis, il vit et travaille entre la France et la Palestine où, dans cet entre-deux géographique et culturel, il développe une pratique artistique pluridisciplinaire (dessin, installation, objets / sculpture, performance, etc.) dont l'image, photo et vidéo, est au centre depuis 2000.

L'œuvre de Taysir Batniji, souvent teintée d'impermanence et de fragilité, puise son inspiration dans son histoire subjective, mais aussi dans l'actualité et l'histoire. Par le biais d'une approche distanciée, il détourne, étire, joue avec son sujet initial, de manière à proposer un regard poétique, parfois grinçant, sur la réalité.

Après sa première exposition personnelle à Paris en 2002, ses œuvres ont été largement exposées en Europe et dans le monde, y compris à la Biennale de Venise ; au Jeu de Paume à Paris ; au Martin-Gropius-Bau de Berlin ; à la Kunsthalle de Vienne ; au Witte de With de Rotterdam et au V\&A Museum à Londres. Taysir Batniji est représenté par les galeries Sfeir-Semler (Hambourg/Beyrouth) et Eric Dupont (Paris).

\footnotetext{
* Elisa Ganivet, doctor of philosophy, art historian, author of Border Wall Aesthetics (Columbia University Press 2020), has worked as a cultural manager and curator for international public and private cultural organizations. Web: www.ElisaGanivet.com
} 
Elisa Ganivet: Taysir, our first contact was about ten years ago when I was writing my PhD in Philosophy on contemporary geopolitical walls and how artists were able to create mobility around the object. From my phenomenological perspective, your Watchtowers series obviously caught my eye. We've been talking a bit over the last few years and finally met at a Parisian café in 2020.

But let's get to the heart of the matter since you have this hot news: your exhibition "Quelques bribes arrachées au vide qui se creuse" (A few snatches torn from the deepening emptiness) at the MAC VAL in Vitry-sur-Seine. This exhibition is a so-called retrospective. Personally, I don't like this expression very much because it gives the impression that you have accomplished everything, whereas no, you still have a lot to do and to make us discover. But what is very beautiful is that we see your own journey as a man, an artist, a Palestinian. It is also the in-between, here neuralgic, that you deliver to us, and that we feel. With the ID Project, 1993-2012, a work that punctuates in a very formal way the administrative meanderings of your history: from your first arrival in Europe, in Italy, until your naturalization in France. However, beyond this aspect, your exhibition is a beautiful capture of this in-between time and we grasp the amplitude of the techniques, supports, mediums with which you work (photography, video, drawing, silkscreen, conceptual installation...). Could you explain to us this notion of in-between, of two geographical spaces, even of two temporalities?

Taysir Batniji: It is true that, for the past ten years, my work has been in an in-between, highlighting the existence of two geographies, two countries, two spaces. Between visibility and invisibility, materiality and immateriality, reality and fiction, the objects and forms I create physically embody this in-between. To My Brother, GHO8O9 and Watchtowers, for example, are dual works: their appearance, invisible for the first and "already seen" for the second, is deceptive and requires a closer look, or closeup, to be perceived accurately. There is a tenuous relationship between what we see from afar and up close, between what we think we see and what really is. While my first works, made at the end of the 1990s, during my first stay in France, evoke a precise place, the one where I come from, where I grew up. They are situated in a historical context, and also reflect my life as a person, an artist, a Palestinian.

Today, I have lived as many years in Palestine as in France. This is why I wanted to update the work Untitled (1998) [Figure 1], the assemblage of objects presenting a suitcase filled with sand. Instead of forming a single pile, in a single section of the suitcase, I decided to present two piles. Because, over the years, the land of the original place, Gaza, Palestine, has been duplicated: I now have another home.

The exhibition at the Mac Val begins with the series of photographs Chez moi, ailleurs (At Home, Elsewhere) (2000, in progress) which insists on this "other home", a present that I give to see, while insisting on its intimate and autobiographical character. It is a selection of images that retrace my life, in bits and pieces, its stages, the different places where I have lived in Europe, transit places (airports, train stations). Until 2006, I was permanently on the move. This work echoes with another home Gaza Diary, which is a photographic series taken during different stays in my original country between 1999 and 2006.

EG: Around the time of the second intifada...

TB: Yes, the second intifada started in 2000, when I decided to
Elisa Ganivet : Taysir, notre premier contact fut il y a une dizaine d'années lorsque j'écrivais ma thèse de philosophie sur les murs géopolitiques contemporains et de la manière dont les artistes créaient une mobilité autour de l'objet. Depuis ma perspective phénoménologique, ta série des Watchtowers m'avait évidemment attiré l'œil. Nous avons un peu échangé ces dernières années et finalement nous nous sommes rencontrés à la terrasse d'un café parisien en 2020.

Mais allons dans le vif du sujet puisque tu as cette actualité brûlante : ton exposition « Quelques bribes arrachées au vide qui se creuse " au MAC VAL de Vitry-sur-Seine. Cette exposition est dite rétrospective. Personnellement, je n'aime pas trop cette expression car cela donne l'impression que tu as tout accompli, alors que non, tu as encore beaucoup à faire et à nous faire découvrir. Ce qu'il y a justement d'impactant c'est que l'on voit ton parcours en tant que toi : une personne, un artiste, un Palestinien. Et c'est également l'entre-deux, ici névralgique, que tu nous fais parvenir, et que nous ressentons dans l'exposition. Avec en filigrane ID Project, 1993-2012, œuvre qui ponctue de façon très formelle les méandres administratifs de ton histoire, de ta première arrivée en Europe, en Italie, jusqu'à ta naturalisation française. Pour autant, au-delà de cet aspect, ton exposition est une belle captation de cet entre-deux et on y saisit l'amplitude des techniques, supports, mediums avec lesquels tu travailles (photographie, vidéo, dessin, sérigraphie, installation conceptuelle...). Pourrais-tu nous expliquer cette notion d'entre-deux, de deux espaces géographiques, voire de deux temporalités?

Taysir Batniji : ॥ est vrai que, depuis une dizaine d’années, mon travail s'inscrit dans un entre-deux, mettant en exergue l'existence de deux géographies, deux pays, deux espaces. Entre visibilité et invisibilité, matérialité et immatérialité, réalité et fiction, les objets et les formes que je crée incarnent d'ailleurs physiquement cet entre-deux. To my Brother, GHO8O9 et Watchtowers sont par exemple des œuvres duelles : leur apparence, invisible pour la première et « déjà vue » pour les secondes, est trompeuse et nécessite un regard approfondi, ou de près, pour être justement perçue. II y a un rapport ténu entre ce que l'on voit de loin et de près, entre ce que l'on croit voir et ce qui est réellement. Tandis que mes premières œuvres, réalisées à la fin des années 1990, lors de mon premier séjour en France, évoquent un lieu précis, celui d'où je viens, où j'ai grandi. Elles sont situées dans un contexte historique, et reflètent également ma vie en tant que personne, artiste, palestinien.

Aujourd'hui, j'ai vécu autant d'années en Palestine qu'en France. C'est la raison pour laquelle j'ai tenu à réactualiser l'œuvre Sans titre (1998) [Figure 1], l'assemblage d'objets présentant une valise remplie de sable. Au lieu de former un seul tas, dans un seul pan de la valise, j'ai

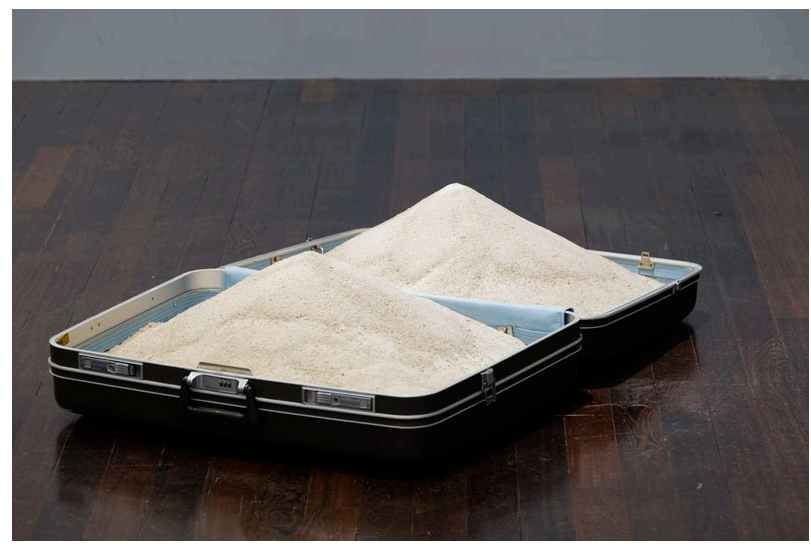

Figure 1. Untitled (1998). Suitcase, sand, variable dimensions. View of the exhibition at MACVAL, 2021. Courtesy of the artist. 
return to Gaza for good. After that, I went back every year until 2006. Then the situation stalled.

EG: Thinking about your travels and moves during this period and while I was visiting the exhibition, I realized that you didn't make large volume artworks, like monumental installations.

TB: Yes. Probably because until 2010, I didn't have a fixed place to work (a studio). For me, it has always been important to be able to store my works. And to be able to move around easily and lightly, without getting bogged down in logistics. I have made many works on paper. Composed of several easily transportable fragments, they unfold in space and can have a monumental scale when exposed. This is also one of the reasons why in traditional terms, I stopped with painting because it requires space, materials, a certain sedentary lifestyle. A different way of life.

EG: Would the installation Inflammable (1997) signal this break?

TB: Yes, there are several works, such as Undefined (1997) [Figure 2] or the untitled key prints on rolled canvas (1997) [Figure 3], that mark this transition from an exclusively pictorial practice to a more multidisciplinary, conceptual practice that evokes the political context in a more concrete, clearer way than before. Even if the starting point remains the personal experience, this one is inscribed in the collective history. The back and forth is permanent.

EG: But precisely, the key is a fundamental element in the Palestinian context. You mention it three times here with the rusty ones on canvas, the glass key ring and also the real estate agency project.

TB: Indeed, for the Palestinians, the key is emblematic. It is a strong symbol because it refers to the history of the Nakba of 1948 , of the dispossession of land, of those Palestinians who kept their keys in the hope of being able to return home one day. The prints of rusty keys on canvas express this collective and historical dimension. While the glass copy of my key ring-the only object I had on me when I found myself unable to return to Gaza in 2006-is more a reminder of a personal trauma.

EG: Related to this symbol, could you explain the real estate agency's project?

TB: These are houses that were bombed during the "Cast Lead" operation carried out at the end of 2008, beginning of 2009 against Gaza. At the time, about 1,500 people died, including 500 children. Many infrastructures and houses were also destroyed. Faced with this destruction, which is reminiscent of the political punishments practiced during the British mandate (the British occupation of Palestine before 1948) and then perpetuated by the Israeli government, my work consisted of paying tribute to these houses and their inhabitants. To make memory. I had the rubble photographed by a friend on the spot who also had the mission of collecting information on these places. I then presented these images in the form of a fictitious real estate agency, in order to create a discrepancy between what the viewer thinks he sees and what he sees.

EG: That's exactly it. While you evoke politics, you manage, through your mode of representation, to bring into play the subtlety of consequences. We don't need to see the raw tragedy. décidé de présenter deux tas. Car, au fil des années, la terre du lieu originel, Gaza, la Palestine, s'est dédoublée : j’ai désormais un autre chez moi.

L'exposition au Mac Val débute d'ailleurs avec la série de photographies Chez moi, ailleurs (2000, en cours) qui insiste sur cet « autre chez moi », un présent que je donne à voir, tout en insistant sur son caractère intime et autobiographique. II s'agit d'une sélection d'images qui retracent ma vie, par bribes, ses étapes, les différents endroits où j'ai vécu en Europe, des lieux de passage (aéroports, gares). Jusqu'en 2006, j'étais en déplacement permanent. Cette œuvre fait un écho avec un autre chez moi : Gaza journal intime, qui est une série photographique prise lors de différents séjours au pays entre 1999 et 2006.

EG : À peu près au moment de la 2ème intifada...

TB : Oui, la 2ème intifada s'est déclenchée en 2000, au moment où j'ai décidé de rentrer définitivement à Gaza. Après, j’y suis retourné chaque année jusqu'en 2006. Ensuite la situation s'est bloquée.

EG : En pensant à tes déplacements durant cette période et alors que je faisais le tour de l'exposition, je me suis fait la réflexion que tu ne réalisais pas d'œuvres en grand volume, de type installations monumentales.

TB : En effet. Sans doute parce que, jusqu'en 2010, je n'ai pas eu de lieu de travail (d'atelier) fixe. Pour moi, il a toujours été important de pouvoir stocker mes œuvres. Et de pouvoir me déplacer facilement et légèrement, sans m'encombrer des questions logistiques. J'ai réalisé beaucoup d'œuvres sur papier. Composées de plusieurs fragments facilement transportables, elles se déploient dans l'espace et peuvent avoir une échelle monumentale sous leur forme exposée. C'est aussi l'une des raisons pour laquelle j'ai rompu avec la peinture, en des termes traditionnels, car celle-ci demande de l'espace, des matériaux, une certaine sédentarité. Un mode de vie différent.

EG : L'installation Inflammable (1997) signalerait-elle cette rupture?

TB : Oui, il y a plusieurs œuvres, comme Undefined (1997) [Figure 2] ou les empreintes de clés sur toiles roulées, sans titre (1997) [Figure 3], qui marquent cette transition entre une pratique exclusivement picturale et une pratique davantage pluridisciplinaire, plus conceptuelle et qui évoque le contexte politique d'une manière plus concrète, plus claire qu'avant. Même si le point de départ reste le vécu personnel, celui-là s'inscrit dans l'histoire collective. Le va-et-vient est permanent.

EG : Mais justement, la clef est un élément fondamental dans le contexte palestinien. Tu la convoques ici à trois reprises avec celles rouillées sur toiles, le trousseau en verre et aussi le projet de l'agence immobilière.

TB : Effectivement, pour les Palestiniens, la clef est emblématique. C'est un symbole fort car se référant à l'histoire de la Nakba de 1948, de la dépossession des terres, de ces Palestiniens qui ont gardé leur clef dans l'espoir de pouvoir retourner un jour chez eux. Les empreintes de clefs rouillées sur toile expriment cette dimension collective et historique. Tandis que la copie en verre de mon trousseau de clefs, le seul objet que j'avais sur moi quand je me suis retrouvé dans l'impossibilité de rentrer à Gaza en 2006, est plus le rappel d'un traumatisme personnel.

EG : Corrélatif à ce symbole, pourrais-tu nous expliquer le projet de l'agence immobilière?

TB : Il s'agit de maisons qui ont été bombardées pendant l'opération " Plomb durci » menée fin 2008, début 2009 contre Gaza. II y a eu à 


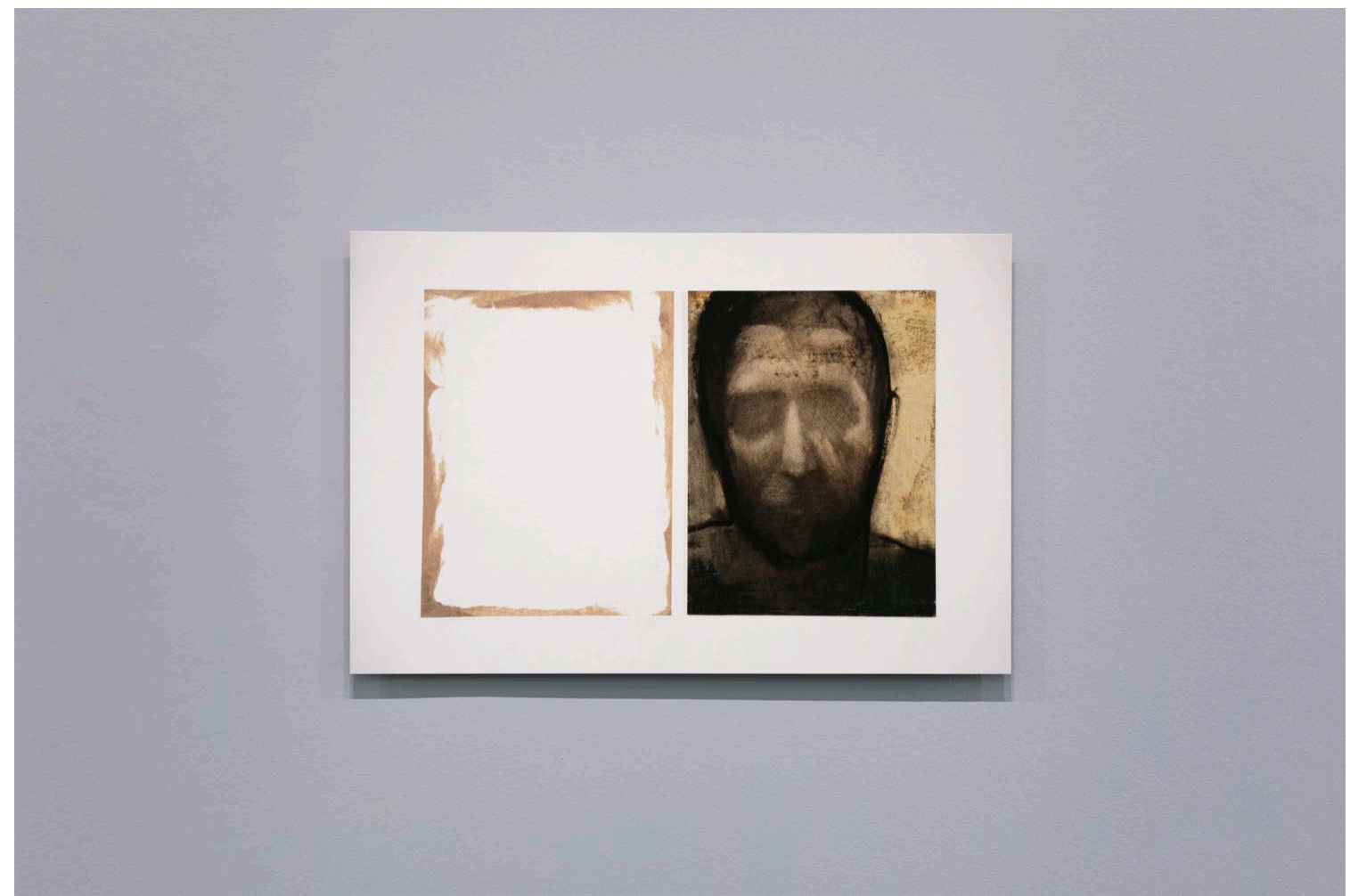

Figure 2. Undefined (1997). Oil on paper, tape, $49 \times 78,5 \mathrm{~cm}$. View of the exhibition at MACVAL, 2021. Courtesy of the artist.

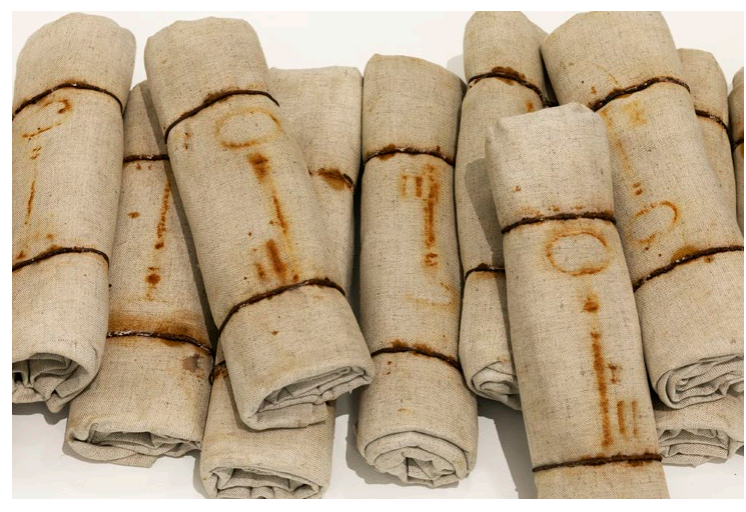

Figure 3. Untitled, detail (1997). Keys imprints on rolled canvas, 20 elements $30 \mathrm{~cm}$ each, View in detail of the exhibition at MACVAL, 2021. Courtesy of the artist.

TB: Yes, it is important to me that my work avoids any victimization, any pathos, any strictly political discourse. To this end, all means are good: fiction, detour... I try to use "filters" to keep a distance.

EG: In the scenography, there is an installation that quite disturbed me. It is the one from your Disruptions series (20152017) [Figure 4] where we see screenshots of Whatsapp conversations with your family. Green covers a large part of the images. We can make out very pixelated streets. The pixel is also one of your favorite motifs. It reminds us of absence, of a materiality that is no longer, or that is becoming. A blur. Moreover, the scenography of the Mac Val transforms this work into a box of vibrations because the wall shakes at the sound of the projection of the video entitled Bruit de fond (2007). l'époque environ 1500 morts dont 500 enfants. De nombreuses infrastructures et habitations ont également été détruites. Face à ces destructions, qui ne sont pas sans rappeler les punitions politiques pratiquées durant le mandat britannique (l'occupation anglaise de la Palestine avant 1948) et perpétuées ensuite par le gouvernement israélien, mon travail consistait à rendre hommage à ces maisons et à leurs habitants. Faire mémoire. J'ai fait photographier les décombres par un ami sur place qui avait aussi pour mission de collecter des informations sur ces lieux. J'ai ensuite présenté ces images sous forme d'une agence immobilière fictive, afin de créer un décalage entre ce que le spectateur croit voir et ce qu'il voit.

EG : C'est justement ça. Alors que tu évoques la politique, tu parviens, par ton mode de représentation, à faire jouer la subtilité des conséquences. On n’a pas besoin de voir la tragédie crue.

TB : Oui, il est important pour moi que mon travail évite toute victimisation, tout pathos, tout discours strictement politique. À cette fin, tous les moyens sont bons : la fiction, le détournement... J'essaye d'avoir recours à des « filtres », de garder une distance.

EG : Dans la scénographie, il y a une installation qui m’a assez troublée. C'est celle de ta série Disruptions (2015-2017) [Figure 4] où l'on voit les captures d'écran de conversations Whatsapp avec ta famille. Le vert recouvre une grande partie des images, on y distingue des rues très pixelisées. Le pixel est aussi un de tes motifs de prédilection. II rappelle l'absence, une matérialité qui n'est plus, ou qui est en devenir. Un flou. De plus, la scénographie du Mac Val transforme cette œuvre en caisson de vibrations car la cimaise tremble au son de la projection de la vidéo justement intitulée Bruit de fond (2007). 


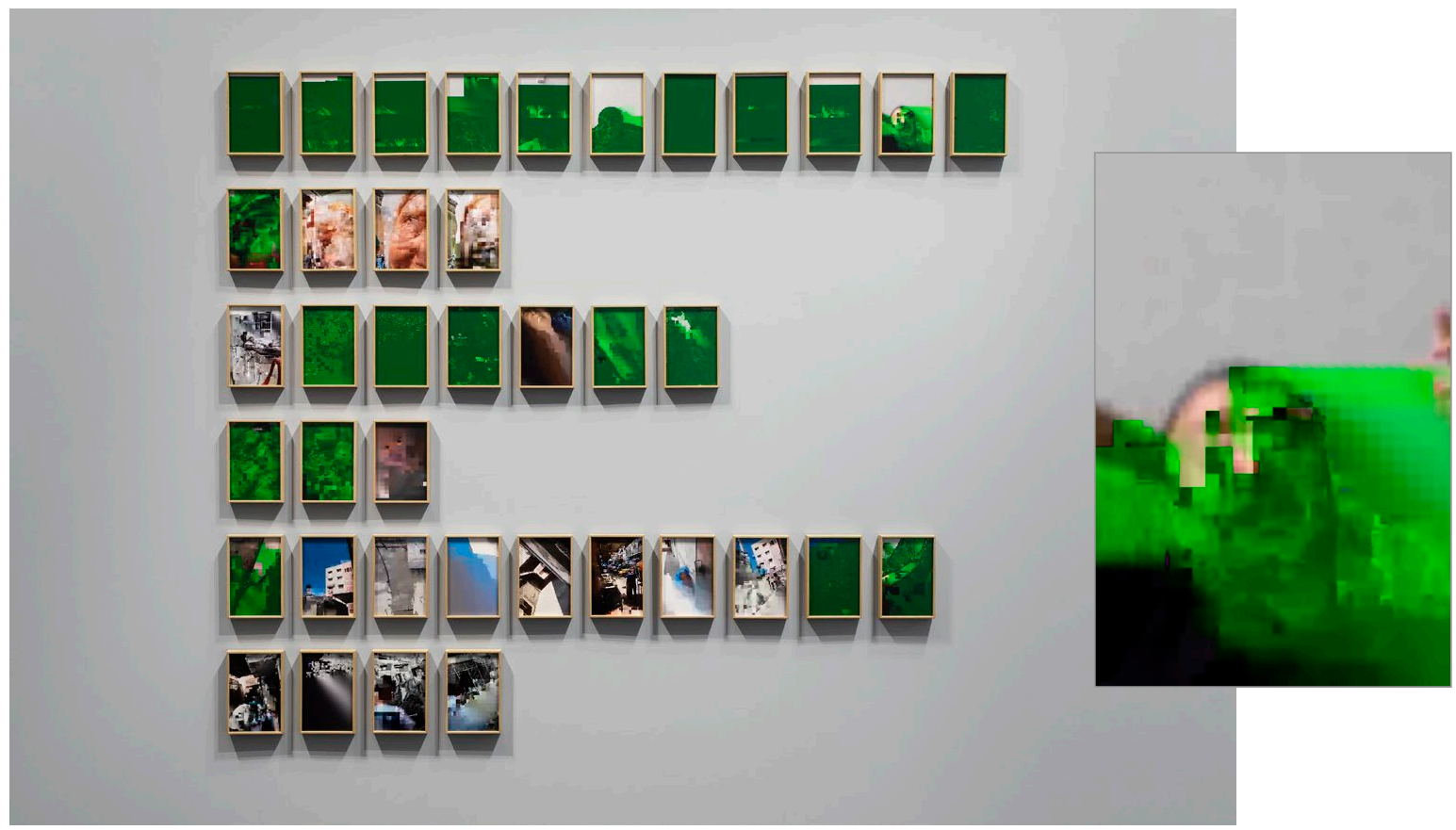

Figure 4. Disruptions (2015-2017). Series of 86 screenshots, inkjet print on Canson Archive satin RC paper, 16 X $24 \mathrm{~cm}$. Detail and view of the exhibition at MACVAL, 2021. Courtesy of the artist.

TB: When I was communicating with my mother and family in Gaza, the screen would regularly blur, due to the poor connection. The disruption of the network was destructuring the images. Interested by this formal phenomenon, and by the way the faces of my relatives and the streets of my neighborhood were transformed, I wanted to capture these moments. Photography has never been an end in itself for me. I like the way this type of project questions the medium.

EG: So what was the process of the Watchtowers (2008) ? [Figure 5]

TB: These are Israeli military watchtowers in the West Bank photographed in the manner of Bernd and Hilla Becher. The two German photographers documented Europe's post-industrial heritage from the 1950s onwards in a documentary style and according to a precise protocol: frontal images taken with a camera, sharp, without human presence, with subdued, neutral light, etc. In 2004, I went to see their retrospective at the Centre Pompidou in Paris. I was already familiar with their work because my wife, Sophie, was doing her DEA on the documentary style and was interested in the German school of Düsseldorf. When I saw their type of water towers, whose cylindrical shape immediately reminded me of Israeli watchtowers, I was hooked. Four years were necessary for the execution. Unable to go there, I had to find a photographer in the West Bank. In 2008, my friend Dominique Abensour, director of Le Quartier in Quimper, invited me to participate in the exhibition "Our Realities". This is how we were able to get the funds for the production.

EG: How did you locate the watchtowers?

TB: I contacted several people to locate them but they are military buildings. There is no known map. Some photographers were afraid to go there because it could be a dangerous environment.
TB : Lorsque j'étais en communication avec ma mère et ma famille à Gaza, l'écran se brouillait régulièrement, en raison de la mauvaise connexion. La perturbation du réseau déstructurait les images. Interpellé par ce phénomène formel, et par la façon dont se transformaient les visages de mes proches et les rues de mon quartier, j'ai tenu à capter ces instants. La photographie n'a jamais été pour moi une fin en soi, j'aime la manière dont ce type de projet interroge le médium.

EG : Quel fut donc le procédé de la série des Watchtowers (2008)? [Figure 5]

TB: ॥ s'agit des miradors militaires israéliens en Cisjordanie photographiés à la façon de Bernd et Hilla Becher. Les deux photographes allemands ont documenté à partir des années 1950 le patrimoine post-industriel européen, dans un style documentaire et selon protocole précis : des images frontales prises à la chambre, nettes, sans présence humaine, avec une lumière tamisée, neutre, etc. En 2004, je suis allé voir leur rétrospective au Centre Pompidou de Paris. Je connaissais déjà leur travail car ma femme, Sophie, faisait son DEA sur le style documentaire et s'intéressait à l'école allemande de Düsseldorf. En voyant leur typologie de châteaux d'eau, dont la forme cylindrique m’a immédiatement rappelé celle des miradors israéliens, j’ai eu le déclic. Quatre années furent nécessaires pour la mise en exécution. Ne pouvant me rendre sur place, j'ai dû trouver un photographe en Cisjordanie. En 2008, mon amie Dominique Abensour, directrice du Quartier à Quimper, m'a invité à participer à l'exposition « Nos réalités ». C'est ainsi que nous avons pu avoir les fonds pour la production.

EG : Comment avez-vous fait pour localiser les miradors?

TB : J'ai contacté plusieurs personnes pour les localiser mais ce sont des bâtiments militaires. II n'y a pas de carte connue. Certains 


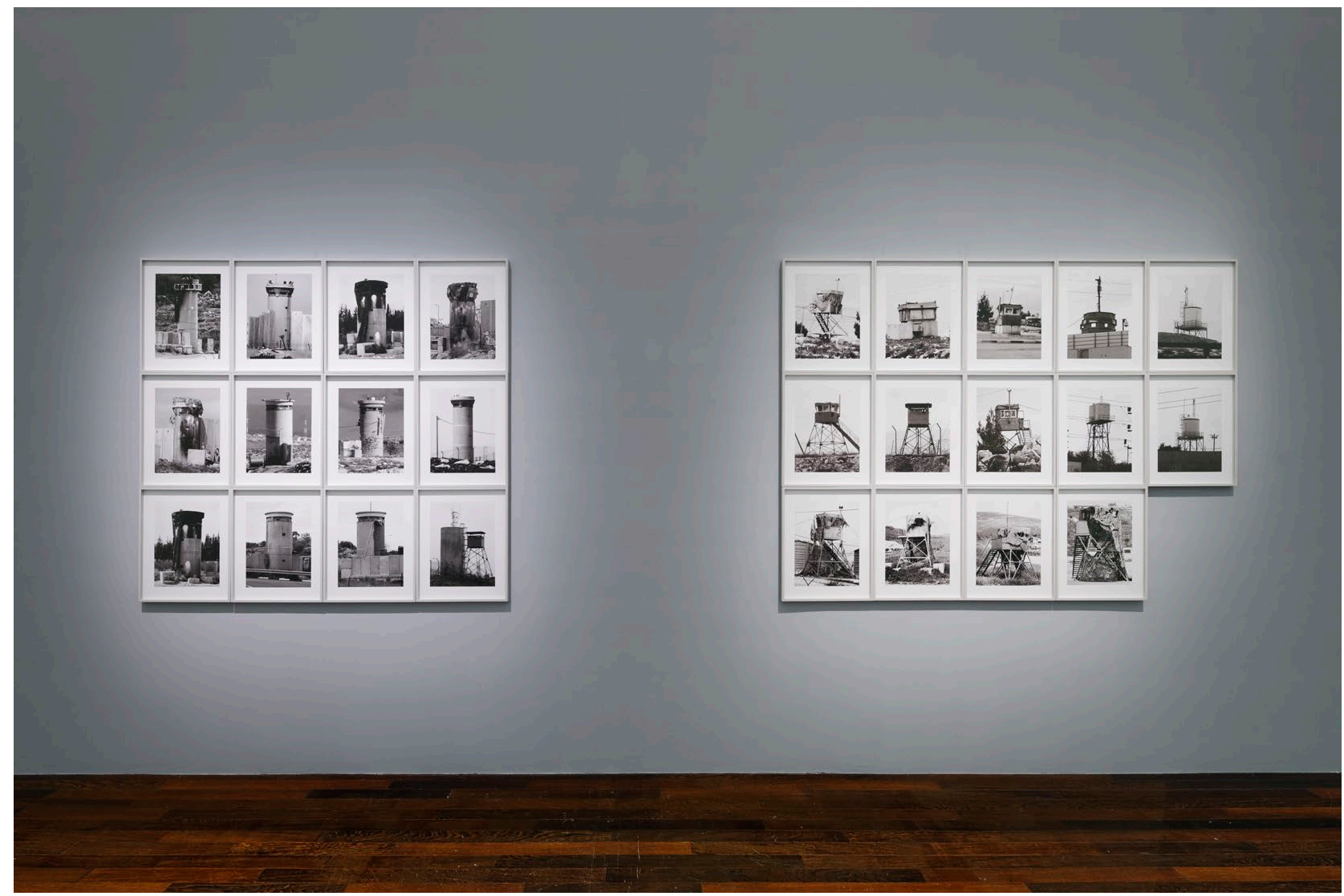

Figure 5. Watchtowers (2008). Series of 26 photographs, black and white digital prints, $40 \times 50 \mathrm{~cm}$. View of the exhibition at MACVAL, 2021. Courtesy of the artist, photo: Dieter Kik.

Other people put me in touch with Israeli photographers who were willing to do this work, but I wanted it to be seen from the Palestinian side. Even if my first idea was to do as the Bechers did, to work with a camera, to take the time... We quickly realized that installing this type of equipment in a guarded military zone, moreover without accreditation, was impossible. The delegated photographer had to work with a normal digital camera equipped with a telephoto lens to take pictures from a distance. Sometimes, he took the picture while passing in a bus or in a car, or even hidden behind a tree... As a result, contrary to the perfect images of the Bechers, who follow the protocol to the letter, the photographs of Watchtowers are sometimes blurred, pixelated, in backlight, etc. Because it was impossible to take the time to pose. What seemed to be flaws eventually became an advantage, because the goal was not to imitate the Bechers identically. It was just enough to create the illusion from a distance. At first glance, one thinks that this is one of their series, but a second time, one realizes that it is not. The precariousness of the photos, their defects, indirectly evoke the situation. Without making a speech on what is a watchtower, on the complexity of the displacement, one feels all this tension which surrounds it, the difficulty, the danger to approach it.

EG: I draw a parallel with one of Rula Halawani's series, The Wall at Night (2004), who herself confessed to being afraid of the concrete wall and approached it at night, as if to tame it.

TB: Indeed, but it must have been complicated for her...

EG: I didn't know and I really like the video Me 2 (2003). It looks like a photographes avaient peur d'y aller car le contexte pouvait être dangereux. D'autres personnes m'ont mis en contact avec des photographes israéliens qui étaient disposés à réaliser ce travail, mais je voulais que ce soit vu du côté palestinien. Même si ma première idée était de faire comme les Becher, de travailler à la chambre, de prendre le temps... On s'est vite rendu compte qu'installer ce type de matériel dans une zone militaire surveillée, de surcroít sans accréditation, était impossible. Le photographe délégué a dû travailler avec un appareil numérique lambda muni d'un téléobjectif pour photographier de loin. Parfois, il prenait la photo en passant dans un bus ou dans une voiture, ou encore caché derrière un arbre... Du coup, contrairement aux images parfaites des Becher, qui suivent à la lettre le protocole, les photographies de Watchtowers sont parfois floues, pixelisées, en contre-jour, etc. Car il était impossible de prendre le temps de la pose. Ce qui semblait être des défauts est finalement devenu un avantage, car le but n'était pas d'imiter les Becher à l'identique. II était juste suffisant de créer l'illusion de loin. Au premier regard, on pense qu'il s'agit d'une de leurs séries, mais dans un second temps, on se rend compte que non. La précarité des photos, leurs défauts, évoquent indirectement la situation. Sans faire de discours sur ce qu'est un mirador, sur la complexité du déplacement, on ressent toute cette tension qui l'entoure, la difficulté, le danger de s'en approcher.

EG : Je fais le parallèle avec l'une des séries de Rula Halawani, The Wall at Night (2004), qui confessait elle-même avoir peur du mur en béton et qui s'en approchait de nuit, comme pour l'apprivoiser. 
Borders in Globalization Review | Volume 3 | Issue 1 | Fall/Winter 2021

Ganivet, "On the Passage of Existence: An Interview with Taysir Batniji"

burst of pure resistance, a scream. We see you turning with two different angles on this song performed by Gloria Gaynor.

TB: I was in Marseille at the time, between the end of 2002 and the end of 2003, when the Americans were preparing the war in Iraq. In spite of all the demonstrations against it, it seemed that everything was heading towards this war. The situation described by the media in France, full of clichés towards the Iraqis, was unclear, ambiguous, even perverse.

EG: A Manichean image?

TB: Yes, while the majority of international opinion was against the war, the positioning of the media did not reflect the reality on the ground, the feelings of the Iraqis, the way they lived the situation. I could no longer watch the television news (France 2, in particular). I decided to install my camera, like a filter, and to film them. With the vague idea that one day I might do something with these rushes. In the end, Me 2 is the assembly of two sequences: on the first one, I turn like a dervish, carrying the camera at arm's length, filming what I see. On the second, the camera is posed (fixed) and films me while shooting. As for the Gloria Gaynor song, I got it from a carnival that I filmed in Marseille. The interweaving of the two sequences produces a double look: that of a man who turns and sees himself turning. This performative video is a spontaneous gesture, a kind of cry against war, a will to win or, at least, to survive.

EG: To face up to it. Precisely in situations where the population is vulnerable and in distress, you also manage to capture, to extract an essence from the situation to make it more universal. We start from our own vulnerability, as individuals, and the added excess by the catastrophic political and geopolitical situations. Your personal experience with Gaza Diary or To my Brother, for example, expresses this.

TB: It is true that To My Brother (2012) [Figure 6] is a special work because it is about my missing brother who was killed by the Israeli army in 1987 at the beginning of the first Intifada. I think
TB : En effet, mais cela a dû être compliqué pour elle...

EG : Je ne connaissais pas et j'aime beaucoup la vidéo Me 2, (2003). On dirait un élan de pure résistance, un cri. On te voit tourner avec deux angles différents sur cette chanson interprétée par Gloria Gaynor.

TB : J'étais à Marseille à l'époque, entre fin 2002 et fin 2003, au moment où les Américains préparaient la guerre en Irak. Malgré toutes les manifestations contre, il semblait que tout allait vers cette guerre. La situation décrite par les médias en France, pleine de clichés envers les Irakiens, n'était pas claire, ambigüe, voire perverse.

EG : Une image manichéenne?

TB : Oui, alors que l'opinion internationale s'est majoritairement prononcée contre la guerre, le positionnement des médias ne rendait pas compte de la réalité sur le terrain, du ressenti des Irakiens, de la manière dont ils vivaient la situation. Je ne pouvais plus regarder les journaux télévisés (celui de France 2, notamment). J'ai décidé d'installer ma caméra, comme un filtre, et de les filmer. Avec la vague idée qu'un jour peut-être je ferai quelque chose de ces rushes. Finalement, Me 2 est l'assemblage de deux séquences : sur la première, je tourne comme un derviche en portant à bout de bras la caméra qui filme ce que je vois. Sur la deuxième, la caméra est posée (fixe) et me filme en train de tourner. Quant à la chanson de Gloria Gaynor, je l'ai récupérée lors d'un carnaval que j'ai filmé à Marseille. L'imbrication des deux séquences produit un double regard : celui d'un homme qui tourne et se voit tourner. Cette vidéo performative est un geste spontané, une sorte de cri contre la guerre, une volonté de vaincre ou, tout du moins, de survivre.

EG : Faire front. Justement dans des situations où la population est vulnérable et en détresse, tu parviens aussi à capter, à extraire une essence de la situation pour nous la rendre plus universelle. On part de notre propre vulnérabilité, en

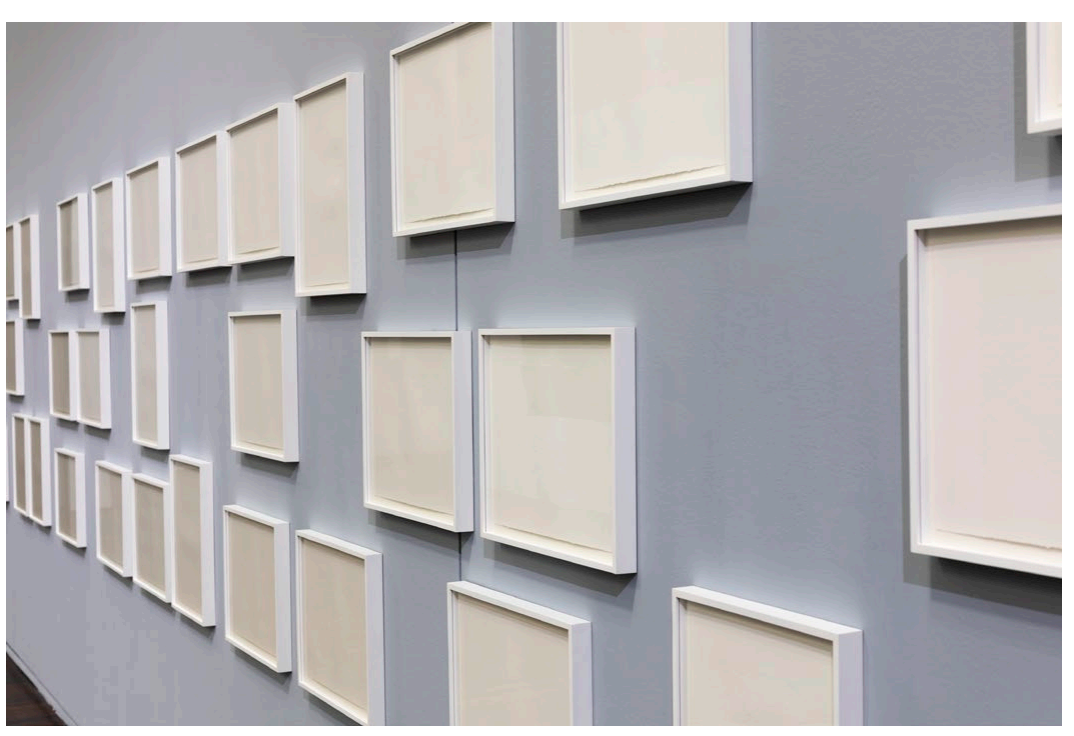

Figure 6. To my brother (2012). Series of 60 hand carvings from photographs on paper, $30.5 \times 40.5 \mathrm{~cm}$. Detail (right) and view of the exhibition at MACVAL, 2021. Courtesy of the artist.

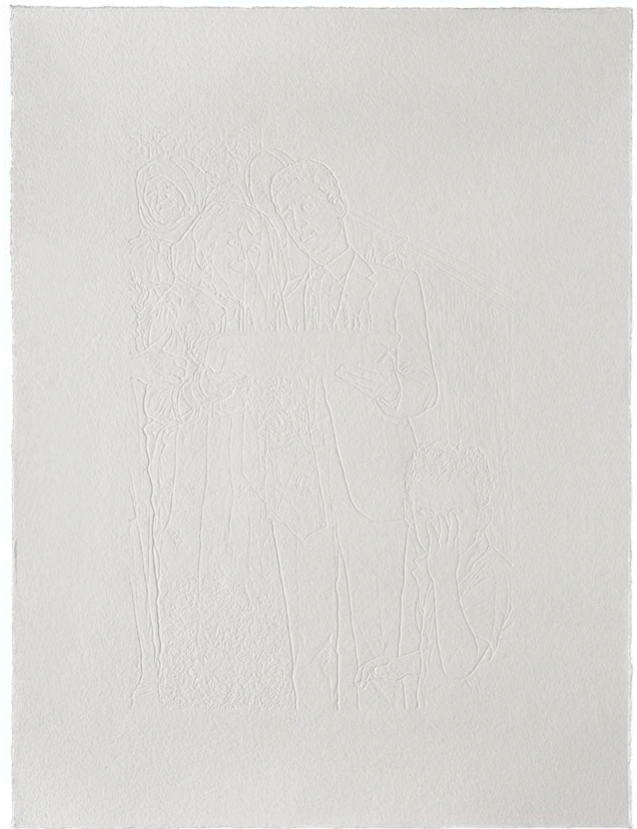


this story affected me a lot and had an impact on my work, especially on the works related to disappearance, absence. Basically, beyond the political prism and current events, beyond the war which can only be a one-off, I am above all interested in the human dimension. What happens on the fringe of the bombings? How do people live? Because nothing lasts forever. In fact, I dedicated one of my works to this observation: Nothing is permanent (2014). Wars, occupation, what a people lives at a time $\mathrm{T}$ are only passages in History. The situations all change one day. And what remains is the human, the daily life. What people do, what they tell.

EG: How did you react to the clashes last spring 2021?

TB: As usual when something happens. I feel helpless, because I am geographically far away. I wonder what I can do. These are times when I am active on Facebook. I try to share, to inform, to comment on events, to help people understand what is going on, to read between the lines. Because obviously I feel concerned. But these are times of anguish, of concern for my family on the spot. I try to call often, to be in contact with my relatives, I make sure they are well, I tell them that I am thinking about them, etc. What is incredible, and painful, is that although these kinds of events make the headlines, as soon as the episode is over, the situation is forgotten. It is forgotten that people are still living with the trauma of what has just happened. Since 2006, there have been four successive wars. A large number of houses have been bombed without ever being rebuilt. The trauma can be seen in the children. There are many cases of suicides. No one talks about it because there is no future, no political perspective. Fifteen years ago, there was still a horizon, a hope that this situation would be resolved. Now there is nothing. The Israeli government literally has "carte blanche". The situation is left to rot, under the pretext that Gaza is controlled by Hamas. But I think that everyone has their share of responsibility. Whatever the position towards Hamas, we forget that the Gazan population did not choose and that, since 2007, they have suffered poverty, malnutrition and insecurity.

EG: What do you think when people mention "diaspora artist"?

TB: I don't really like labels. And I've always had a reluctance to use the word "exile". It's a very heavy word. It's a word with no way out. For my part, I always keep the hope of being able to go home, to live here and there, I refuse to consider myself as "exiled".

EG: But here this is also your home, you have a family, you have built...

TB: Yes of course, but I am cut off from my home there. My children were only able to go to Gaza once. They were very small. And it's hard for me to pass on the language to them.

EG: But they understand you when you speak to them in Arabic.

TB: A little. They have one Arabic class a week because I want them to learn, not to lose contact with the language. I try to speak to them every day in Arabic but it's not easy every day.

EG: Speaking of transmission, you went to see your family who lives in California. You had done this project with drawings tant qu'individu, et du surplus ajouté par les situations politiques et géopolitiques catastrophiques. Ton expérience personnelle avec par exemple Gaza journal intime ou To my Brother l'exprime.

TB : Il est vrai que To my Brother (2012) [Figure 6] est une œuvre particulière puisqu'il s'agit de mon frère disparu, tué par l'armée israélienne, en 1987, au début de la première Intifada. Je pense que cette histoire m'a beaucoup affectée et qu'elle a eu un impact sur mon travail, notamment sur les œuvres en lien avec la disparition, l'absence. Au fond, au-delà du prisme politique et de l'actualité, au-delà de la guerre qui ne peut être que ponctuelle, je m'intéresse surtout à la dimension humaine. Que se passe-t-il en marge des bombardements ? Comment vivent les gens ? Car rien ne dure jamais. D'ailleurs, j'ai consacré l'une de mes œuvres à ce constat : Rien n'est permanent (2014). Les guerres, l'occupation, ce que vit un peuple à un instant « $\mathrm{t}$ » ne sont que des passages dans l'Histoire. Les situations changent toutes un jour. Et ce qui reste c'est l'humain, la vie quotidienne. Ce que font les personnes, ce qu'elles racontent.

EG : Comment as-tu réagi face aux affrontements du printemps de 2021 ?

TB : Comme d'habitude lorsqu'il arrive quelque chose. Je me sens impuissant, car je suis géographiquement loin. Je me demande ce que je pourrais faire. Ce sont des périodes durant lesquelles je suis actif sur Facebook. J'essaye de partager, d'informer, de commenter des événements, d'aider les gens à comprendre ce qu'il se passe, à lire entre les lignes. Car évidemment je me sens concerné. Mais ce sont des périodes d'angoisse, d'inquiétude pour ma famille sur place. J'essaye de téléphoner souvent, d'être en contact avec mes proches, je m'assure qu'ils vont bien, je leur dis que je pense à eux, etc. Ce qui est incroyable, et douloureux, c'est que, bien que ce genre d'événements fasse la une des journaux, dès que l'épisode est fini, la situation retombe dans l'oubli. On oublie que les gens continuent à vivre le traumatisme de ce qu'il vient de se passer. Depuis 2006, il y a eu quatre guerres successives. Un grand nombre de maisons ont été bombardées sans jamais être reconstruites. Le traumatisme se lit à travers les enfants. II y a beaucoup de cas de suicides. Personne n'en parle car il n'y ni avenir, ni perspective politique. Il y a une quinzaine d'années, il y avait encore un horizon, un espoir de voir cette situation se résoudre. Maintenant, il n'y a plus rien. Le gouvernement israélien a littéralement carte blanche. On laisse la situation pourrir, sous prétexte que Gaza est contrôlée par le Hamas. Mais je pense que chacun a sa part de responsabilité. Quelle que soit la position vis-à-vis du Hamas, on oublie que la population gazaouie n'a pas choisi et que, depuis 2007, elle subit pauvreté, malnutrition et insécurité.

EG : Que penses-tu lorsque l'on mentionne « artiste de la diaspora »?

TB : Je n'aime pas trop les étiquettes. Et j’ai toujours eu une réticence à l'égard du mot « exil ». C'est un mot très lourd. Sans issue. Pour ma part, je garde toujours un espoir de pouvoir aller chez moi, de vivre ici et là-bas, je refuse de me considérer comme « exilé ».

EG : Mais ici c'est aussi chez toi, tu as une famille, tu as construit...

TB : Oui bien sûr, mais je suis coupé de chez moi là-bas. Mes enfants n'ont pu aller à Gaza qu'une seule fois. Ils étaient très petits. Et j'ai du mal à leur transmettre la langue.

EG : Mais ils te comprennent quand tu leur parles en arabe.

TB : Un peu. Ils ont un cours d'arabe par semaine car je tiens à ce qu'ils apprennent, qu'ils ne perdent pas le contact avec la langue. J'essaye de leur parler au quotidien en arabe mais ce n'est pas facile tous les jours.

EG : En parlant transmission, tu es parti voir ta famille qui vit en Californie. 

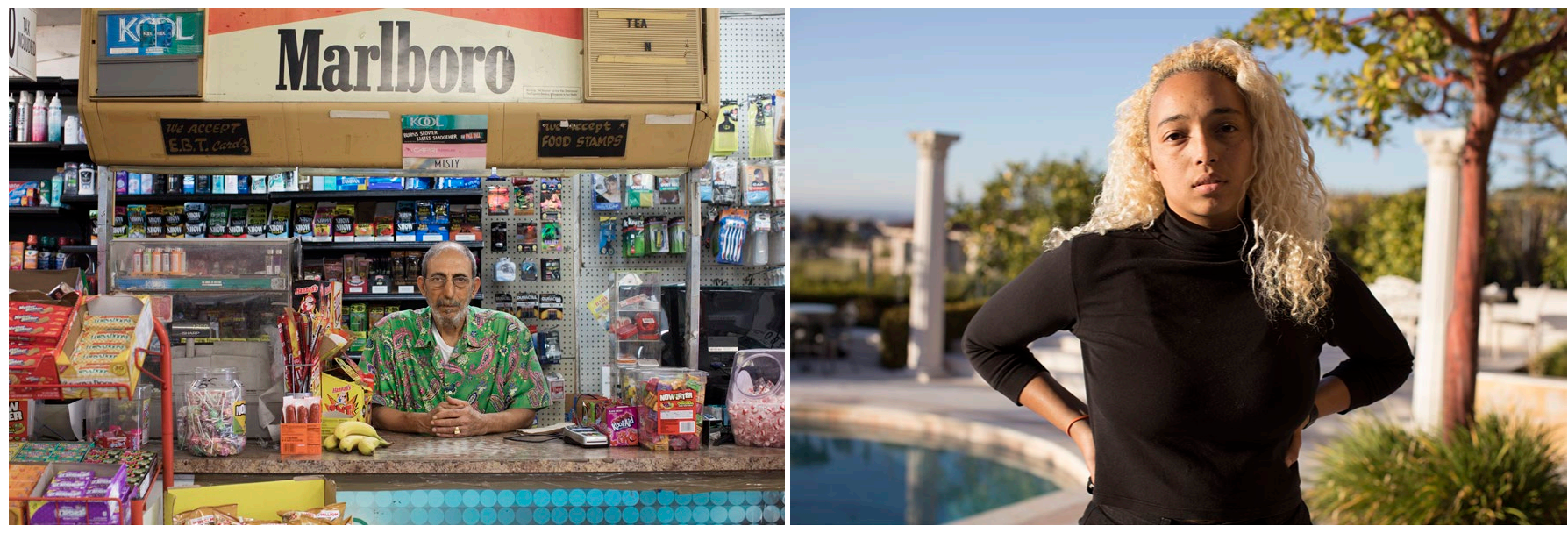

Figure 7. Home Away From Home / Adam (2017). Series of 26 pigment inkjet prints on Canson photo satin premium paper, $55 \times 37 \mathrm{~cm}$. Courtesy of the artist.

and photographs: Home Away from Home / Adam (2017) [Figure 7].

TB: Yes, it was a funny situation because my cousins turned out to be both familiar and foreign. I knew them very young and very little. They moved to the United States in the late 1960s to the mid-1980s. So, once I was at their home, I felt a certain frustration because I was in the midst of my family, yet I felt like a stranger. Like I was in Gaza without being there. This ultimately exacerbated my frustration at not being able to be with my family in Gaza. It also awakened memories, situations that were buried inside me.

EG: In your exhibition at the Mac Val, we understand in particular the coherence and evolution of your thinking. But more than continuity, I think there is a lot of endurance in the body of your work.

TB: That's what was important in this exhibition and, for me, it's a great opportunity to be able to gather my work, to have visibility, to step back on what l've done so far. It's like an assessment, a time for reflection, before continuing. It's a gestation in progress.

EG: To see what will come next, step by step... To remain patient.

TB: Yes, in the middle of this very particular period, because of Covid among other things. At the moment I am preparing an exhibition at the Mathaf in Doha. So I still have to wait before going back to the heart of my creative process.
Tu avais réalisé ce projet avec dessins et photographies: Home Away from Home / Adam (2017) [Figure 7].

TB : Oui, c'était une drôle de situation car mes cousins se sont avérés être à la fois familiers et étrangers. Je les ai connus très jeune et très peu. Ils se sont installés aux États-Unis entre la fin des années 1960 et le milieu des années 1980. Alors, une fois chez eux, j'ai senti une certaine frustration car j'étais au sein de ma famille, tout en me sentant étranger. Comme si j'étais à Gaza sans y être. Cela a finalement exacerbé ma frustration de ne pouvoir être avec ma famille de Gaza. Cela a également réveillé des souvenirs, des situations qui étaient enfouies en moi.

EG : Dans ton exposition au Mac Val, on comprend en particulier toute la cohérence et l'évolution de ta pensée. Mais plus qu'une continuité, je pense qu'il y a beaucoup d'endurance dans le corpus de ton œuvre.

TB : C'est ce qui était important dans cette exposition et, pour moi, c'est une belle opportunité de pouvoir rassembler mes œuvres, d'avoir une visibilité, du recul sur ce que j'ai réalisé jusque-là. Comme un bilan, un temps de réflexion, avant de poursuivre. C'est une gestation en cours.

EG : De voir ce qui va se profiler ensuite, step by step... De rester patient.

TB : Oui au milieu de cette période très particulière, à cause du Covid entre autres. En ce moment, je prépare une exposition au Mathaf de Doha. Alors je dois encore attendre avant de retourner au cœur de mon processus de création. 


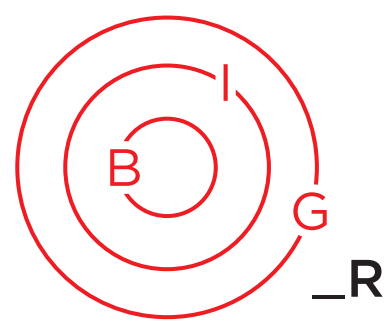

\section{ART \& BORDERS}

En français

\title{
Frontières \& Mythologies personnelles : un entretien avec Emeric Lhuisset
}

\author{
Elisa Ganivet *
}

Connu pour son travail de terrain dans les zones de conflit, le photographe Emeric Lhuisset a été interviewé par Elisa Ganivet. En se concentrant sur les projets contextuels de l'artiste, ses expériences in situ sont révélatrices de dynamiques territoriales singulières. Des extraits de l'entretien sont reproduits ici, dans la section spéciale Art \& Borders de cette édition La version anglaise a été publiée dans notre précédent numéro de BIG_Review (ici).

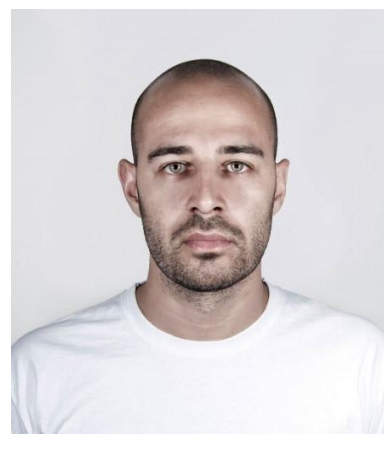

www.emericlhuisset.com

\section{A propos de l'artiste}

Né en 1983, Emeric Lhuisset a grandi en banlieue parisienne. Diplômé en art (Ecole des Beaux-Arts de Paris) et en géopolitique (Ecole Normale Supérieure Ulm - Centre de géostratégie / Université Paris 1 Panthéon-Sorbonne). Son travail est présenté dans de nombreuses expositions à travers le monde (Tate Modern à Londres, Museum Folkwang à Essen, Institut du Monde Arabe à Paris, Frac Alsace, Stedelijk Museum à Amsterdam, Rencontres d'Arles, Sursock Museum à Beyrouth, CRAC Languedoc-Roussillon, Musée du Louvre Lens...). Récemment il remporte la Résidence BMW pour la Photographie 2018 et Grand Prix Images Vevey - Leica Prize 2017. II a également été nominé notamment pour le Photographic Museum of Humanity Grant 2018 (Honorable Mention), pour le prix Coal (2016), pour le prix Magnum Foundation Emergency Fund (2015), pour le prix Niépce (2015), pour le Leica Oskar Barnack Award (2014) ainsi que pour le Prix HSBC pour la photographie (2014). II publie chez André Frère Editions et Paradox (Ydoc) Maydan - Hundred portraits (2014), Last water war (2016), chez André Frère Editions et Al-Muthanna L'autre rive (2017) et aux Editions Trocadero Quand les nuages parleront. Son travail est présent dans de nombreuses collections privées ainsi que dans celles du Stedelijk Museum, du Musée Nicéphore Niepce et du Musée de l'Armée - Invalides. En parallèle de sa pratique artistique, il enseigne à l'IEP de Paris (Sciences Po) sur la thématique art contemporain \& géopolitique. II est représenté par Kalfayan Galleries.

\footnotetext{
* Elisa Ganivet, doctor of philosophy, art historian, author of Border Wall Aesthetics (Columbia University Press 2020), has worked as a cultural manager and curator for international public and private cultural organizations. Web: www.ElisaGanivet.com
} 


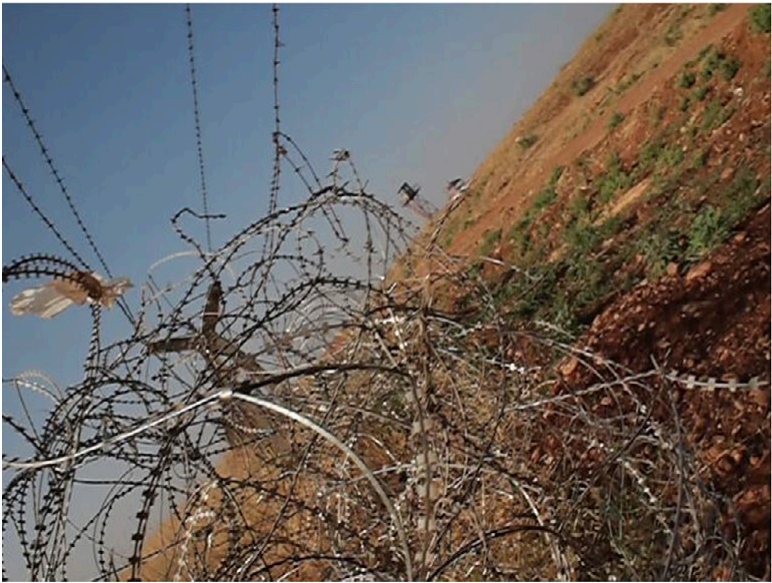

Figure 1. Passage de frontière, Syrie-Turquie, video still, 2010-2018. (c) Emeric Lhuisset. Courtoisie de l'artiste.

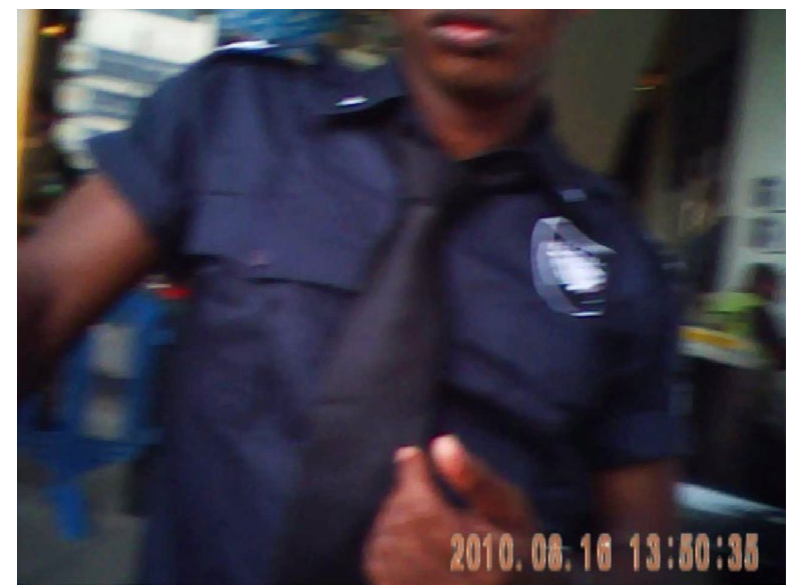

Figure 2. Voyage, archive photographique personnelle, 2010. (c) Emeric Lhuisset. Courtoisie de l'artiste.

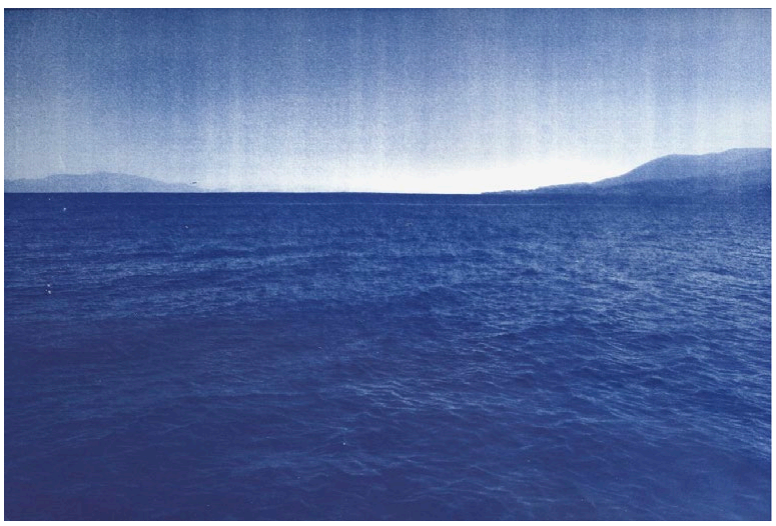

Figure 3. L’autre rive, Irak, Syrie, Turquie Grèce, Allemagne, Danemark, France, 2011-2017. ( Emeric Lhuisset. Courtoisie de l'artiste.
Elisa Ganivet : Emeric, tu es un artiste internationalement reconnu pour tes recherches de terrain en zones de conflit, essentiellement menées au Moyen-Orient, tout autant qu'en Ukraine, en Colombie... La photographie est ton outil de prédilection et on t'en découvre d'autres au fil des années. Lorsqu'en préambule nous avions émis ensemble cette notion de la frontière, ta première remarque fut de souligner le fait que la guerre et la frontière étaient inextricablement liées. Dans ton corpus d'œuvres, il y en a-t-elles qui font explicitement référence à cette idée, à cette sensation de frontière ? Je pense en particulier à ton film Quand les Nuages parleront où à la fin on te suit, en caméra portée, dans l'un de tes franchissements clandestins, l'un des nombreux qui tu as pu faire entre la Syrie et la Turquie. Cette vidéo s'inscrit-elle dans une pratique spontanée ou bien dans une vision de les regrouper ultérieurement?

Emeric Lhuisset : Non pas spécialement mais je me suis toujours intéressé à cette idée de frontière, aussi bien à celle étatique que celle que l'on peut avoir au sein même d'un état. Par exemple sur le territoire israélien, (sans même parler du palestinien), il y a des endroits qui sont complétement morcelés. Déjà en 2010, les hangars pour prendre les bus s'apparentait à des aéroports avec des portiques, des scanners etc. Tu devais passer des barrières pour entrer dans un marché ou ensuite tes sacs étaient fouillés. En France aujourd'hui, on remarque que le dispositif sécuritaire s'est normalisé mais ce n'était pas du tout le cas à l'époque. Les nombreux checkpoints que j'ai pu passer lorsque j'ai travaillé en Irak, en Afghanistan, en Syrie, en Turquie ou même en Colombie, sont toujours une épreuve lourde et compliquée. Jusqu'au dernier moment, on ignore si on y parviendra, si les laisser-passer sont conformes aux attentes. II faut parfois ruser ce qui peut être oppressant. L'expérience est identique au Pakistan, un visa classique ne suffit pas pour passer des check points dans les zones tribales. En Irak, alors que j'avais un simple visa pour les zones kurdes, je passais des check points pour entrer dans les zones arabes. Donc il ne s'agit pas forcément de frontières purement étatiques mais d'un morcellement de l'espace. Cette sensation m'a toujours marqué. II y a aussi le cas des frontières qui ne sont pas visibles à l'œil nue. C'est le cas dans la forêt amazonienne par exemple où l'on traverse de la Colombie au Brésil sans le savoir. Cela m'a d'ailleurs causé quelques problèmes.

Ces vidéos réalisées, entre la Syrie et la Turquie sont des archives personnelles. Je documente régulièrement mes projets, mais ces archives, ne sont initialement pas destinées à être montrées [Figures 1 \& 2]. J'ai finalement décidé d'inclure cette séquence du passage de la Syrie vers la Turquie dans un projet sur les réfugiés au long court (2010-2018) et plus global. Ce qui m’a intéressé est ce moment précis « du devenir réfugié » lorsque les personnes qui fuient la guerre en Syrie franchissent les fils de fer barbelés 
Borders in Globalization Review | Volume 3 | Issue 1 | Fall/Winter 2021 Ganivet, "Frontières \& Mythologies personnelles : Entretien avec Emeric Lhuisset"
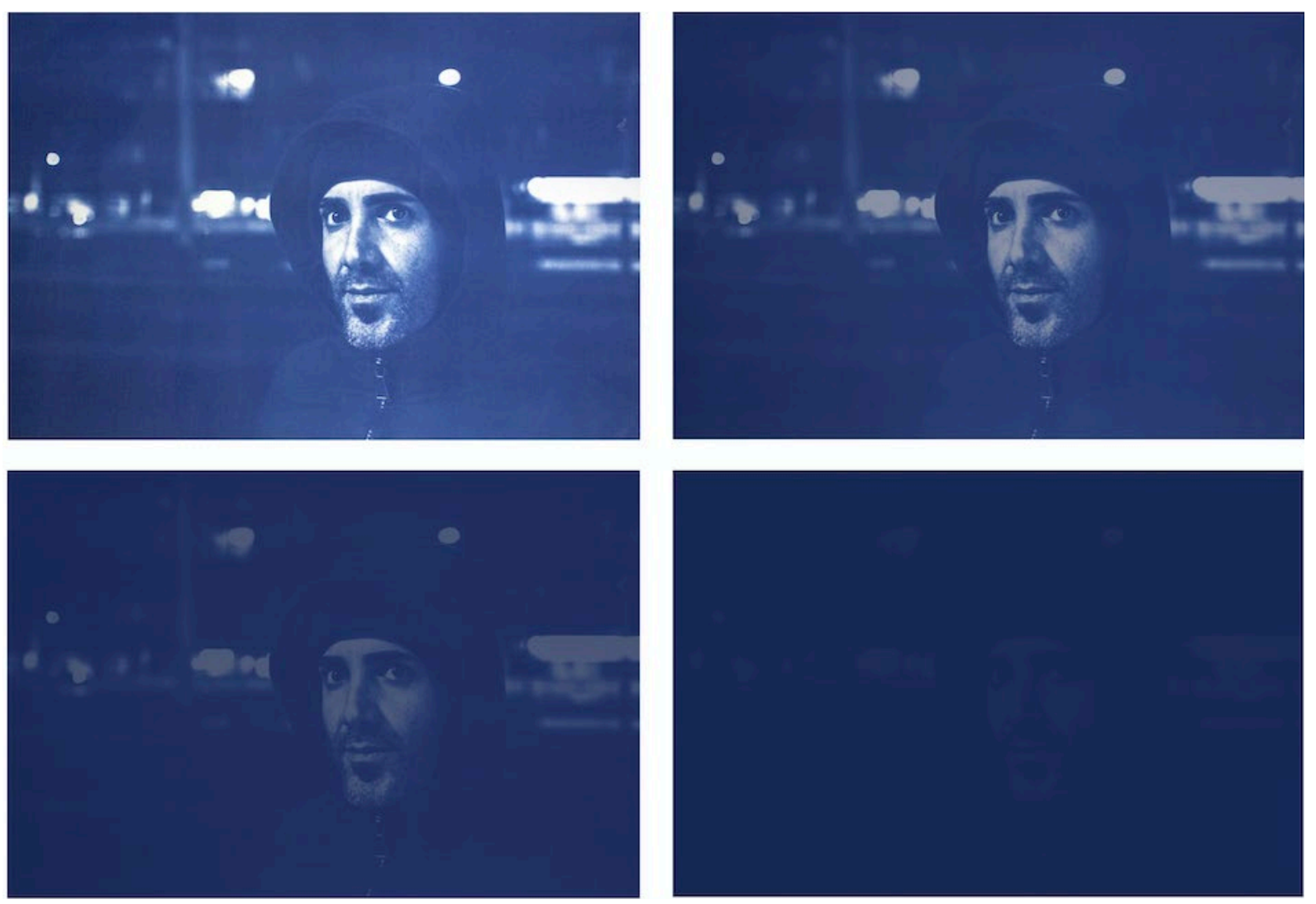

Figure 4. @ Emeric Lhuisset. L’autre rive, Irak, Syrie, Turquie Grèce, Allemagne, Danemark, France, 2011-2017. Courtoisie de l'artiste.

qui séparent ces des deux états. II s'agit d'un instant. Quelques centimètres avant, ils ne le sont pas encore, quelques centimètres après oui.

Inscrire cette séquence dans ce projet est un révélateur car j'aborde un préambule et un destin. C'est l'histoire de ces personnes avant d' « être réfugiées», celles qui le sont devenues ou qui auraient pu le devenir. Est également abordé le thème du franchissement : celui de la traversée en mer, celui de la traversée de l'Europe, puis de l'arrivée jusqu'à un territoire où ces personnes vont se fixer Avec le projet L'autre rive (2011-2017) [Figures 3 \& 4] ce qui m'intéresse c'est de parler de ces amis rencontrés en Irak ou en Syrie, devenus réfugiés, que j'ai retrouvé huit ans plus tard en Europe.

Dans mon livre intitulé Souvenirs de Syrie (2012) [Figures 5 \& 6], j'avais déjà réutilisé des archives personnelles. C'est lorsque je vivais avec des combattants rebelles syriens, caché dans une grotte dans la montagne que des photographies de ce quotidien très étranges avaient été prises. Un quotidien fait de bombardements, de tirs mais aussi d'attente et de tension. Initialement, je voulais le documenter pour mes propres archives. Mais un an après, alors que je regardais de nouveau ces images car l'un de mes amis avaient été tué et que je voulais me le remémorer par ce biais, je me suis dit qu'il fallait montrer ces photographies car elles étaient importantes, qu'elles témoignaient d'une réalité ignorée par beaucoup. La question qui se posa alors fut de comment les montrer car il ne s'agissait pas d'œuvres conçues comme telles. De plus, ces images étaient parfois très dures, assez violentes. On y voyait des gens torturés, des maisons détruites suite à un bombardement et toutes les atrocités qui accompagnent... Pour moi, accrocher ces images à un mur n'avait pas de sens, la tournure était obscène. J'avais aussi songé les donner à la presse.

EG : Mais ce geste aurait été à l'encontre de ta démarche artistique.

EL : L'idée c'était de rendre visible ces images, ce quotidien. Il était pour moi primordial de témoigner. Si la presse s'en emparait, il fallait savoir de quelle manière et en choisir les modalités. Mais comme ces images étaient déjà trop vieilles, elles avaient un an, leur obsolescence en terme journalistique m'a interpellé. II semble que même une image d'une semaine soit déjà dépassée. Cette dimension est un peu absurde car pour illustrer un article d'un homme en Syrie en train de tirer du haut de sa fenêtre, que cette photographie aie deux jours ou cinq ans, l'action reste la même. Vouloir qu'une photographie soit la plus fraîche, la plus instantanée possible est un peu absurde, dans ces situations. Du fait de mon impossibilité à utiliser mes archives personnelles 
auprès des médias, il me fallait déterminer qu'en faire. La mémoire d'une guerre est-elle envisageable lorsque celle-ci est toujours d'actualité ? Cette option ne me semblait pas non plus appropriée. J'ai finalement décidé d'en faire un livre noir sans texte, comme une boite noire, un album de famille: Souvenirs de Syrie. Ces photographies n'existent donc que dans ce livre.

EG : Ce que tu interroges dans le quotidien des zones de conflits, c'est aussi les moments d'attente, d'ennui, d'angoisse. Tu retranscris ces guerres en effaçant tout effet sensationnel, de sensationnalisme. Dans ta dynamique de comprendre la guerre, dans sa mise en scène, dans sa construction, tu intègres à $360^{\circ}$ le fait d'être devant, derrière, autour, soit l'environnement territorial. Tu parviens ainsi à définir les mécanismes de la guerre mais on perçoit aussi le respect porté envers le combattant. Cela est possible grâce à ta constance sur du long terme, en créant des liens de confiance et amicaux. Sur les dernières minutes, de ton film Quand les nuages parleront, on comprend ce franchissement illégal de la Turquie vers la Syrie. Cet extrait m'a personnellement touché car nous touchons ici le cœur de l'acte. Puis tu rends hommage, par un portrait, à l'un de tes amis qui a disparu en essayant de traverser
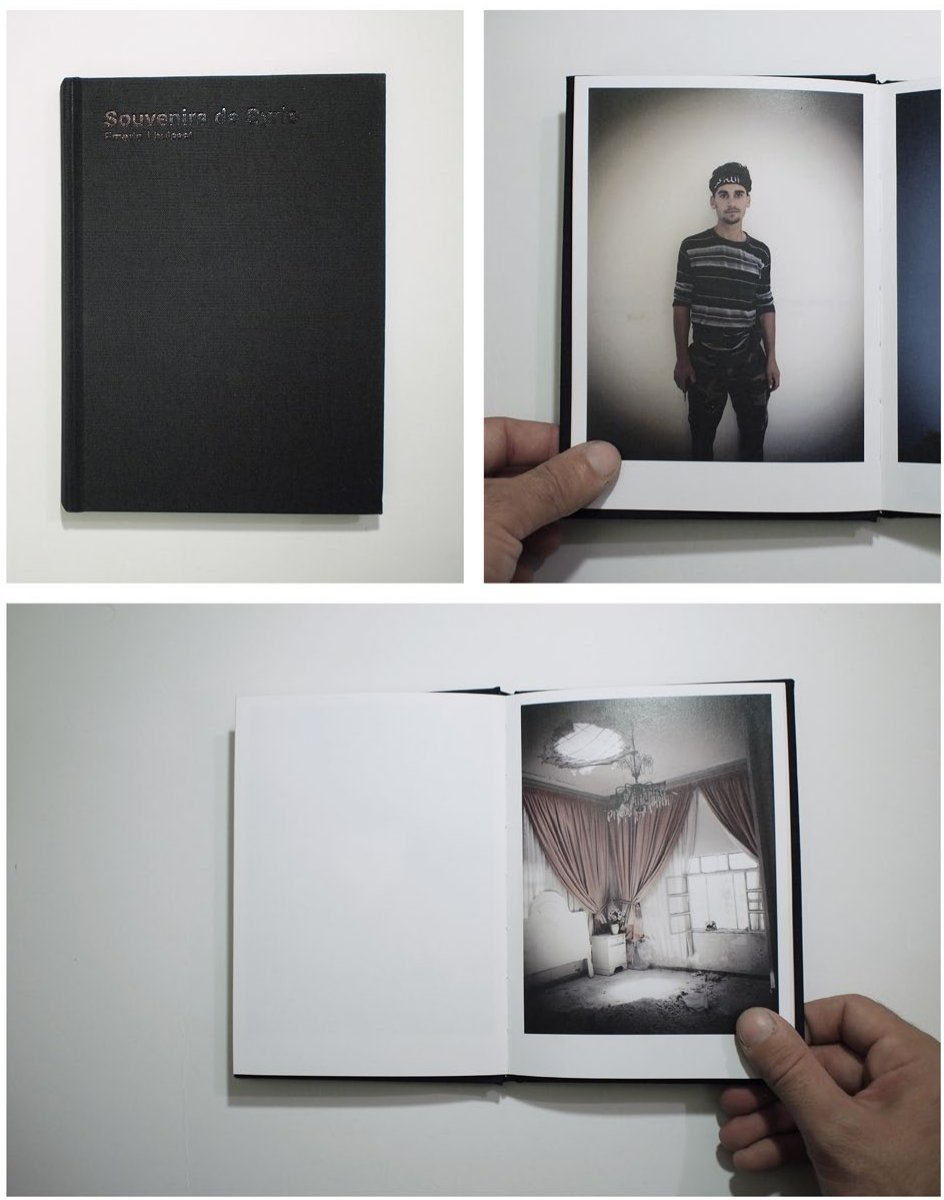

Figure 5. Souvenirs de Syrie, Alep et province d'Idlib (Syrie) juin et août 2012-livre réalisé en 2013. (C) Emeric Lhuisset. Courtoisie de l'artiste. une frontière. Cette expérience dévoilée et sincère est quelque chose que l'on voit rarement dans l'ensemble de la production artistique qui traite, de près ou de loin, nos thématiques.

EL : J'ai choisi de mettre cet extrait de vidéo à la fin de ce film car il fait particulièrement sens avec la question des kurdes. Le territoire kurde est plus vaste que celui que l'Etat turc lui-même. Les kurdes se trouvent dans plusieurs états. C'est ou c'était aussi le cas des Arméniens et des Assyriens dont je parle également. II s'agit de différents peuples existant sur ce vaste territoire mais aussi au-delà des frontières de ce territoire. Finalement ce sont des peuples qui transgressent cette notion de frontière étatique. D'autre part j'ai également voulu terminer avec cette vidéo parce que mon ami Hamidreza est mort sur le tracé d'une frontière, celle qui sépare la Turquie de l'Irak lors d'un bombardement de l'aviation turque. Effectivement, j'ai voulu lui dédier ce film car il m'avait beaucoup aidé notamment pour la série Théâtre de guerre (2011-2012) [Figures 7 \& 8]. II se trouvait que sans comprendre pourquoi je n'avais plus de ses nouvelles jusqu'à ce que des amis m'annoncent qu'il était décédé. Ce franchissement de la frontière reflète aussi cette histoire.

EG : Le concept de frontière est complétement ambivalent. Les géographes eux-mêmes peine à s'accorder sur une même définition. On peut évoquer une ligne, ce qui restreint à l'outil cartographique, originairement militaire. On parle aussi de réseau, de maillage, qui est sans doute plus pertinent lorsque l'on touche le limitrophe.

EL : C'est aussi une zone de tension.

EG : Oui bien sûr. A ce propos, le géographe Claude Raffestin énonce la frontière comme coupure, celle qui contraint l'individu du fait des contrôles, du dispositif et renfort sécuritaire de l'infrastructure. On pense à une coupure, telle une brèche entre deux mondes.

EL : Je n'ai pas théorisé la notion de la frontière mais oui, je pense pouvoir dire que c'est ce qui va séparer. Ce sont des populations, des communautés, qui à travers la création d'un Etat et de frontières, ont décidé de ne pas vivre avec d'autres qui sont à côté. A la base l'idée de frontière est hyper violente, si on l'analyse de ce point de vue-là.

EG : Raffestin dit aussi de la frontière que c'est une couture, quand on envisage les flux et interdépendances sociales, sociétales, économiques...

EL: Une couture ou alors je vois plutôt une suture, car ce sont deux éléments qui ont été 
ensemble puis déchirés, séparés. On crée des ponts à partir de cela.

EG : C'est là aussi une autre image. On parle souvent de Frontières-ponts et de Frontières-murs. Lorsque l'on vit le territoire, on s'en rend bien compte.

EL : Oui, la plaie à soigner d'un côté et la plaie restée ouverte de l'autre. Si on reste dans la métaphore [rires]. En fin de compte, mes expériences avec les frontières ne sont pas très bonnes, mon ressenti est celui d'une vraie tension autour. Car sans même regarder des panneaux les annonçant, on peut détecter lorsque l'on s'en approche. Les militaires sont généralement plus lourdement armés, voire casqués alors qu'ailleurs ils ne le sont pas etc.

EG : Nous-même quand nous étions enfants, avant les accords de Schengen de 1992, avons vécu cette forme de tension au passage de la frontière.

EL : Oui tout à fait. Je me souviens d'anecdotes à ce sujet lorsque je partais en train en Allemagne avec ma grandmère. Elle me rassurait au sujet des douaniers français qui effectivement, en uniformes décontractés, étaient sympas et nous laissaient passer. Elle m'avait averti sur les douaniers allemands qui quant à eux portaient des uniformes stricts et ne nous souriaient pas. J'ignore s'il s'agissait pour elle d'un flashback de la 2nde guerre mondiale ou le fait de montrer nos papiers, mais cette traversée de la frontière la stressait énormément. Aujourd'hui cela nous paraít tellement lointain, voire absurde. Grâce au quasi effacement des frontières en Union Européenne, on est arrivé à quelque chose de très agréable. Mais lors de mon travail en 2016 sur les réfugiés, en passant de l'Allemagne au Danemark, j'avais été choqué par les danois qui avaient posé un checkpoint à la frontière. Afin de de documenter, j'avais pris des photographies avec eux en me faisant passer pour un touriste un peu idiot afin qu'ils ne se méfient pas.

EG : Nous vivons actuellement un repli de la frontière à cause de la pandémie.

EL : Oui, en espérant que ce ne soit qu'une parenthèse.

EG : Par contre, tu te réfères à une méthodologie, celle de l'utilité de jouer au touriste idiot afin de documenter ces situations particulières. Mais peux-tu nous expliquer ton approche lorsque tu te déplaces sur des territoires tels que l'Irak, la Syrie, l'Afghanistan...

EL : Dans ce cas de figure, je fais très peu d'images. Ma démarche est complétement différente dans les
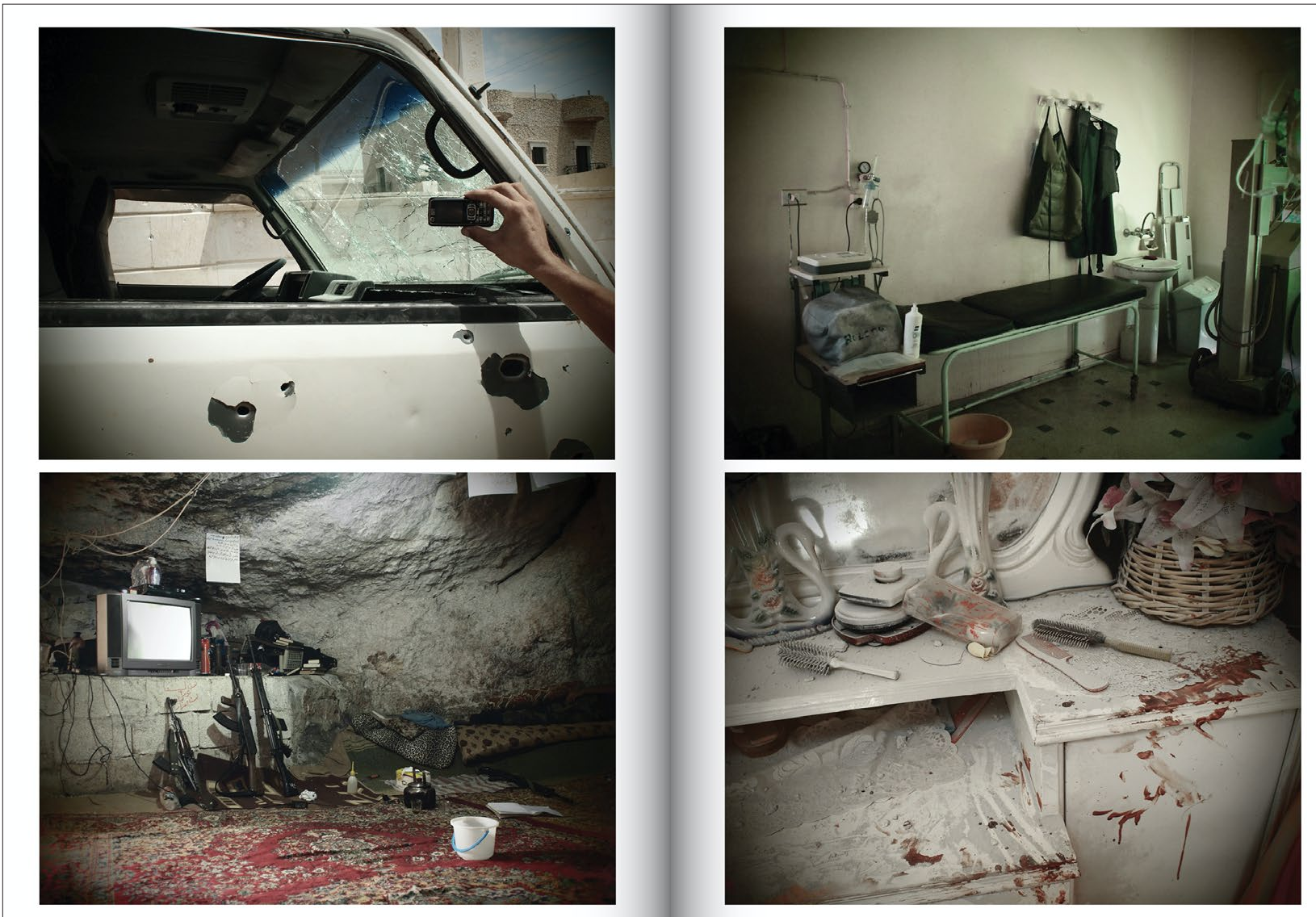

Figure 6. Souvenirs de Syrie, Alep et province d'Idlib (Syrie) juin et août 2012-livre réalisé en 2013. () Emeric Lhuisset. Courtoisie de l'artiste. 


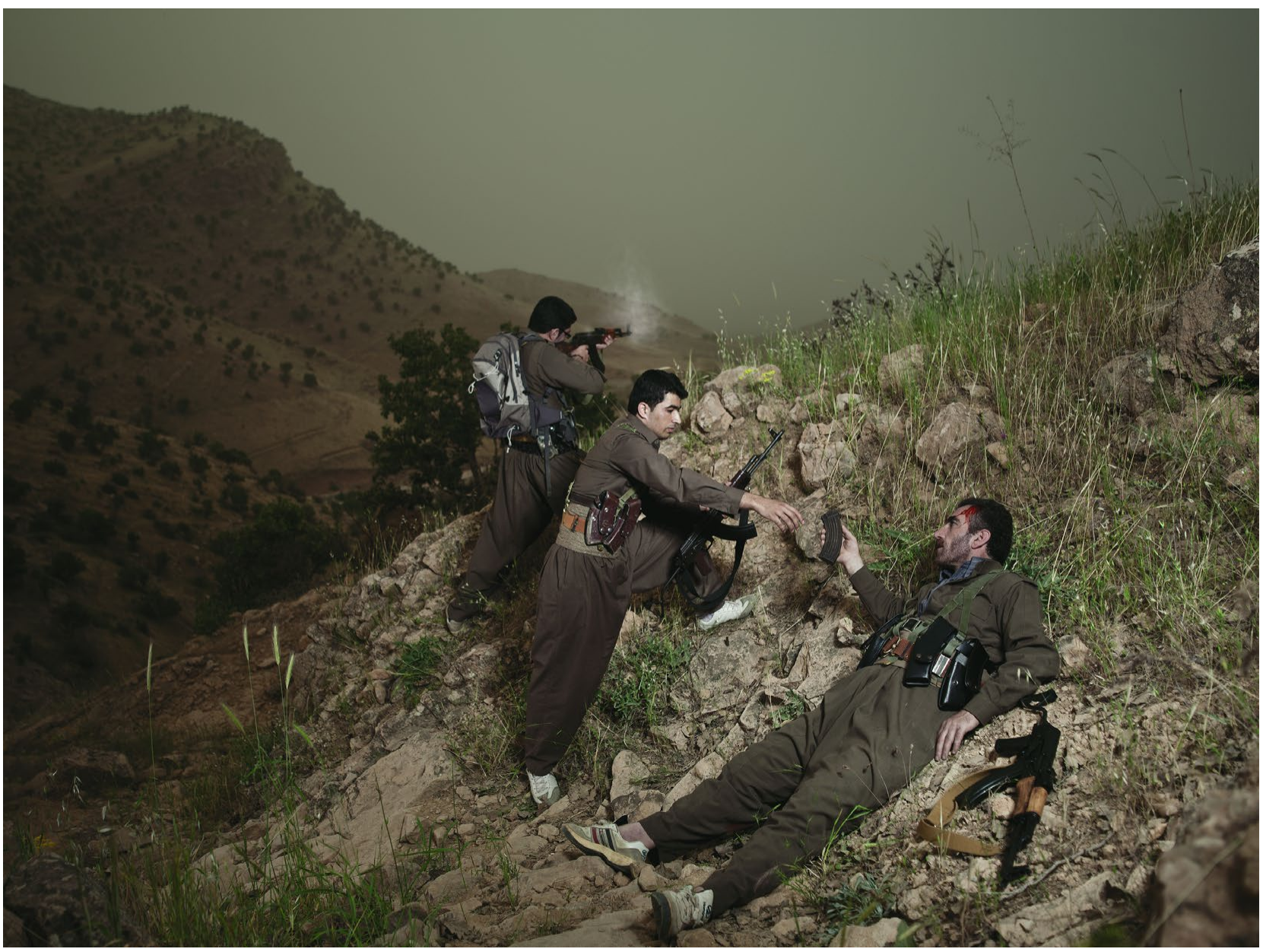

Figure 7. Théâtre de guerre, photographies avec un groupe de guérilla Kurde, Irak, 2011-2012. (c) Emeric Lhuisset. Courtoisie de l'artiste.

zones de conflit. Dans un premier temps, je rencontre des personnes et leur parle de mon travail. Cela peut prendre des années pour obtenir ce genre d'images car elles sont basées sur des relations de confiance. II m'a fallu trois ans pour réaliser la série Théâtre de guerre qui comporte quatorze images. Dans la durée, on ne peut pas mentir aux gens. Ils se rendent bien compte de qui tu es. Je n'ai d'ailleurs pas cherché à leur mentir, j'ai juste raconté ce que je faisais, ce qui m'intéressait, ce que je voulais dire. On a parlé, construit ensemble le projet. Et c'est vraiment cette démarche qui m'intéresse. En effet, lorsque j'arrive, c'est avec ma culture, mon bagage, avec tout cette mythologie personnelle comme dirait Roland Barthes. Les personnes que je vais rencontrer ont également la leur. C'est alors que nous confrontons nos regards, non pas dans l'affrontement mais dans l'échange. On va réfléchir et construire ensemble le projet. Mes idées, ma culture ne font pas forcément sens pour eux. Lorsque je fais une œuvre ce n'est pas là-bas pour ici. Cette œuvre doit être aussi pertinente là-bas qu'ici. Pour moi c'est essentiel. C'est la raison pour laquelle j'expose aussi beaucoup au Moyen-Orient. J'essaye de montrer mon travail aussi là-bas et pas juste de le faire là-bas. Je traite de sujets qui me sont assez éloignés parce que j'ai besoin d'avoir assez de distance avec mon sujet de travail pour pouvoir le traiter. II m'est très difficile d'aborder des sujets dont je suis trop proche. Par exemple, j'ai grandi en banlieue parisienne et on m'a souvent demandé pourquoi je ne travaillais pas sur ce sujet. II me manquerait la distance et l'objectivité nécessaires. J'ai ce besoin d'avoir une distance sur mes sujets, qu'ils n'aient au préalable pas de lien direct avec moi-même. C'est un parti pris en somme.

EG : Néanmoins actuellement, avec nos restrictions de voyages dus à la pandémie, tu es en train de développer un projet pour lequel tu iras au domicile des personnes.

EL : Oui mais c'est finalement habituel dans mon travail. Par exemple, lorsque je suis avec des groupes armés, ou avec les réfugiés, on partage une intimité. Dans ce cas précis, j'ai été les retrouver et les ai suivis en tant qu'ami. C'est ce qui m'a permis de faire ce genre d'images. J'ai documenté des moments passés avec des amis.

EG : Mais là c'est en France du coup.

EL : Mon travail avec les réfugiés s'est déroulé dans un premier temps en Allemagne et au Danemark. Puis dans un deuxième temps en France, pour ce qui concerne la 
seconde génération. J'ai travaillé avec Inès dont le père avait quittél'Algérie, avec Sarah dont le père avait quitté l'Irak de Saddam Hussain, tout comme le père de ma cousine, donc mon oncle. Finalement dans ma famille... [rires] Je travaille beaucoup dans et avec l'intimité. J'aime comprendre les gens. L'approche est anthropologique, voire même psychanalytique. C'est tardivement que je me suis rendu compte de cette dimension, celle qui consiste à se pencher sur les gens eux-mêmes, sur ce qu'ils pensent. Pendant toute ma scolarité aux Beaux-Arts, je suivais des cours de psychanalyse de l'art avec Christian Gaillard. D'avoir étudié les écrits de Jung, Freud etc. m'a certainement influencé car instinctivement, je demandais aux gens si telle chose ne leur renvoyait pas à telle autre etc. Sur le terrain, je procède de la même façon. Au début, les groupes de guerilla te sortent un discours calé sur celui de la propagande du groupe. Cela n'a rien de négatif, c'est juste l'image qu'ils souhaitent donner. Pour passer au-delà, la dimension psychanalytique est bienvenue. II s'agit de comprendre l'individu, les raisons qui l'ont amené à arriver à cette situation, vers quoi il souhaite aller. En dehors de tout discours, qu'est-ce qui l'intéresse véritablement ? Et on en revient à : « Ah oui mais quand j'étais petit... ». C'est fascinant car c'est souvent lié.

EG : Si de part et d'autres ta démarche de compréhension de la personne est la même, tu dois aussi trouver des traits psychologiques communs entre chaque combattant.

EL : Oui mieux comprendre le profil des combattants avec qui je vais travailler est une étape fondamentale. On se livre mutuellement, ce qui sur des zones de guerre n'est pas sans risque. Ma vie est un peu entre leurs mains. Lorsque tu te retrouves avec un groupe de guerilla dans une grotte en Syrie, ta vie ne vaut pas chère, ou au contraire elle le vaut. II faut instaurer une confiance mutuelle. Lorsque les combattants me laissent faire des images, ils se donnent à moi aussi. II est fondamental de comprendre les personnes à qui tu te livres. Au sein du groupe, de la communauté, il faut savoir à qui tu peux faire plus ou moins confiance. Comprendre l'ensemble des mécanismes est utile à la fois pour le projet, pour ma propre sécurité, mais aussi simplement par intérêt humain. II marrive fréquemment d'essayer de comprendre des personnes dont l'idéologie est aux antipodes de la mienne. J'essaye de comprendre les mécanismes d'une pensée avec laquelle je ne suis personnellement pas d'accord. En saisissant ses mécanismes, je peux essayer de les déconstruire. Notamment vis-à-vis des regards portés

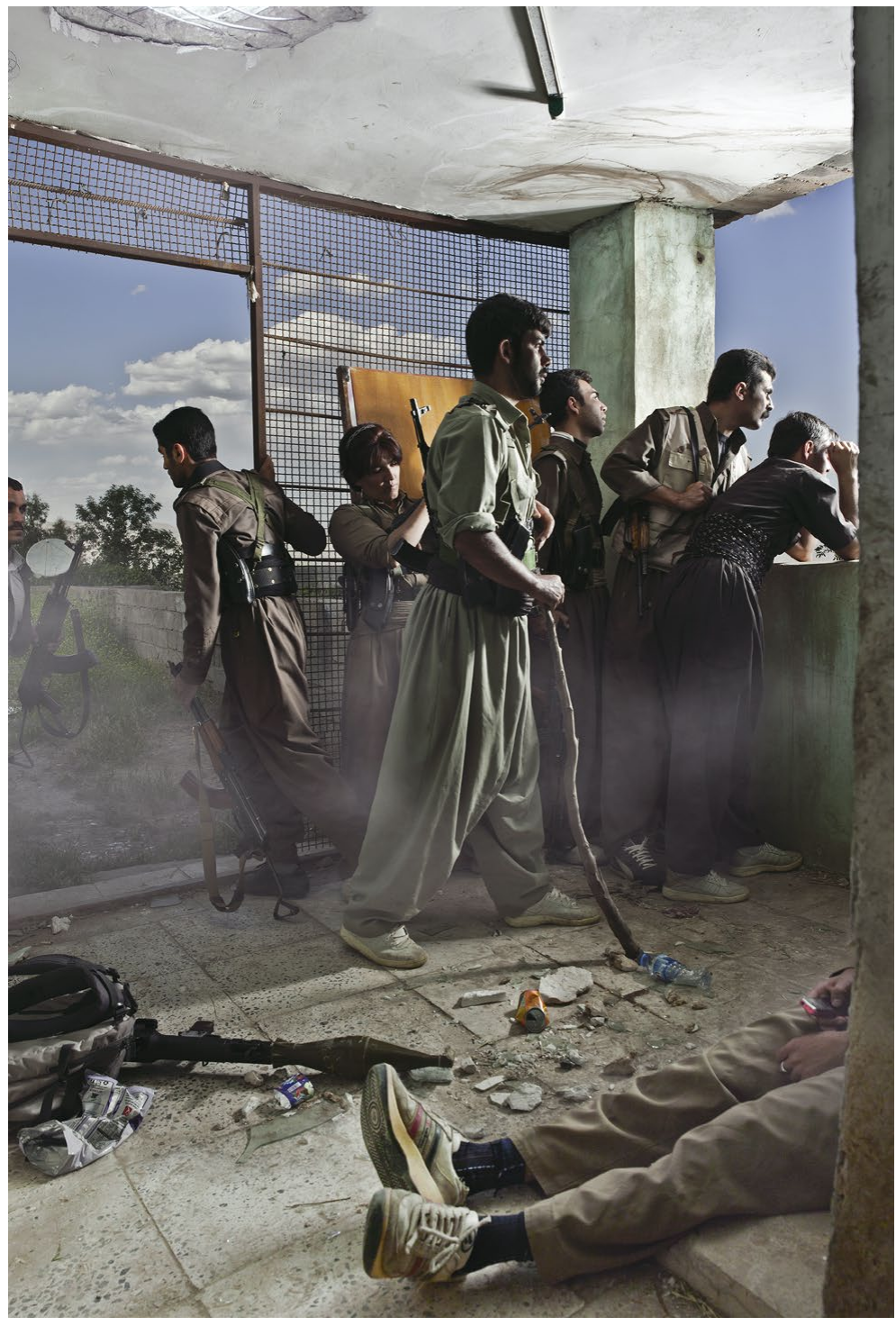

Figure 7. Théâtre de guerre, photographies avec un groupe de guérilla Kurde, Irak, 2011-2012. (c) Emeric Lhuisset. Courtoisie de l'artiste. haineux. Alors qu'en approfondissant, tu t'aperçois qu'il s'agit rarement d'un sentiment de haine, fait d'ailleurs très rare, mais plutôt d'une incompréhension et de la peur. De l'incompréhension qui entraîne de la peur, qui entraîne à son tour un discours très violent. Donc, si on s'arrête au premier regard qui s'apparente à de la haine, la suite de l'approche sera erronée et on ne parviendra pas à déconstruire les regards.

EG : Pourquoi souhaites-tu déconstruire ce type de regards?

EL : Car j'estime que certains d'entre eux sont injustes, qu'ils créent de la violence, un danger à la fois pour les personnes contre lesquelles ils se dressent mais aussi pour la société en son entier. Beaucoup de gens avec ce regard a priori haineux vont le partager, vont mettre en place des leaders qui vont décider en fonction. C'est de cette façon que les sociétés totalitaires, les 
absurdités dangereuses, les massacres, les génocides etc. arrivent. Leur cause revient essentiellement à ce type de mécanisme donc il est pour moi essentiel de déconstruire ce type de regards.

EG : Comment perçois-tu cette crispation, cette montée des populismes, des nationalismes? Je pense en particulier à l'AFD en Allemagne, ce qui est un comble dans le sens où l'on ne pensait pas que cela pouvait arriver dans ce pays.

EL : C'est très inquiétant. C'est la raison pour laquelle il faut d'autant plus essayer de déconstruire les regards. II faut tenter de se dresser contre. Mais pas comme un mur, ce n'est pas la solution. Car les gens finiront par taper dessus et le casser. Donc plutôt s'insinuer et essayer non pas de les convaincre, mais plutôt les inviter à se poser des questions. Par exemple, j'ai mis en parallèle mon travail sur les réfugiés avec celui des combattants kurdes. Il y a entre les deux un écart de huit ans. Ce qui m'intéresse c'est que d'un côté ces combattants sont héroïsés quasiment à l'unanimité en Occident, quelques soit les bords politiques. Les personnes qui sont dans le rejet des réfugiés, idéalisent également ces combattants kurdes : ils sont ceux qui ont combattu Daesh. Sauf que dans mon projet, c'est précisément ces mêmes combattants, ces personnes que tu retrouves huit ans plus tard, devenues des réfugiés. Or il y a tout un pan de la population qui considère les réfugiés comme des parias, des parasites alors même qu'ils héroïsent ces combattants kurdes. Or comment peut-on héroïser une personne et une fois que celle-ci a franchi la mer, la considérer comme un paria, un parasite ? Les gens ne font pas forcément d'emblée ce rapprochement. C'est en le confrontant sur ce point que des doutes, des fissures dans leur rhétorique, leur idéologie, vont se créer. II s'agit de fissurer ces idéologies afin qu'elles ne s'effondrent. C'est tout du moins la manière dont j'essaye de procéder. C'est flagrant lors de présentations publiques de mon travail. A Paris-Photo par exemple, lorsque j'ai dévoilé mon travail sur les réfugiés, certains dans l'assistance n'avaient pas véritablement envie d'écouter. Néanmoins au fur et à mesure, en racontant les histoires individuelles des réfugiés, les yeux de l'auditoire se sont un peu éclairés, comme si quelque chose s'était passé en eux. La visite terminée, ils finissaient par discuter entre eux du sujet, revenaient voir certaines images etc. Ce sont ces mêmes personnes qui au début se disaient qu'elles allaient suivre la visite par politesse. Et c'est donc à ce moment précis que je me dis que cela fonctionne. Les gens ne vont pas forcement changer leur idéologie mais ils vont commencer à s'interroger, peut-être autrement. Et c'est pour moi essentiel.

EG : Alors que ces combattants sont héroïsés, lorsqu'ils arrivent sur un territoire en Occident, en l'occurrence ici en France, c'est précisément la question de l'autre, le rapport à l'Altérité qui survient. On a bien vu les répercussions de la « crise migratoire » en 2015 et encore aujourd'hui, celles qui ont conduit à un repli des frontières. Que faire de cet Autre qui dérange ? Comme tu le précises, la peur et l'incompréhension guident, alors que l'on a besoin de l'autre. L'excuse est souvent au terme démographique, mais le besoin va bien au-delà.

EL : Selon moi c'est une peur qui a été créée par des politiques. II y a un jeu sur la méconnaissance, l'ignorance, afin d'appuyer leur pouvoir. On arrive toujours à cette recherche d'avoir un bouc-émissaire. De tout temps cette recherche apparaît. Ça a été le juif, le protestant, le gitan... celui qu'on ne connait pas ou du moins que l'on connait mal. J'ai beaucoup travaillé sur la Turquie où le pouvoir repose et se construit sur l'idée même d'un ennemi intérieur. Qu'il s'agisse des arméniens, des assyriens, des grecs pontiques, des alévis, des kurdes : il faut toujours construire un ennemi de l'intérieur.

EG : Ce qui est effrayant c'est le relais pris par les nouvelles technologies où on finit par rester dans son propre clan, sans possibilités de traverse. Les passerelles entre les savoirs, les connaissances sont moindre.

EL : Je me pose beaucoup de questions par rapport aux nouvelles technologies. Oui effectivement, ça facilite la communication des idées.

EG : Mais le cadre reste entre nous, nos communautés.

EL : Oui mais n'était-ce pas déjà le cas avant ? J'ai retrouvé par exemple un livre édité en France dans les années vingt : « Le complot juif-allemand ». Ce genre de livres circulait, s'échangeait. Les complots ont toujours existé, avant même l'apport technologique. Elles permettent juste d'accélérer l'information, comme l'a été l'invention de l'imprimerie. Le vrai problème, à mon avis, c'est qu'en fin de compte ceux qui pourraient travailler à la déconstruction des complots n'y parviennent pas assez efficacement. Les médias reconnus regroupent une information accessible mais très tôt il y a eu l'alternative d'internet et des réseaux sociaux. Celle-ci a été très vite accaparée par ceux dont l'information ne pouvait pas passer par les grands médias. La toile leur a servi à diffuser leurs idées, ce qui n'était pas forcément le cas pour la majorité des médias classiques qui n'en avaient pas besoin car ils possédaient déjà leurs canaux de diffusion. Du coup, ils sont arrivés plus tardivement sur un champ déjà investi par les complotistes. Bien sûr poser le doute est assez sain mais le problème est la manière dont on s'interroge. De quelles connaissances sur le sujet dispose-t-on? Qui est le narrateur? Certains complots sont extrêmement complexes à démêler car solidement construits, mélangeant vraies et fausses informations. De plus, le complot peut avoir un effet séduisant dans ce qu'il apporte comme réponse facile. Alors qu'il faudrait aussi savoir accepter de ne pas savoir, on ne peut avoir réponse à tout! 


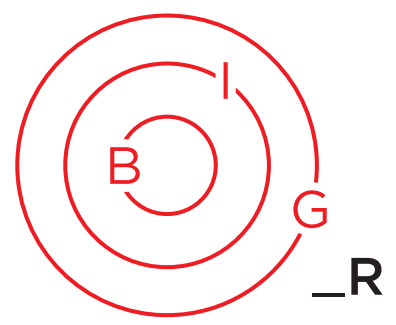

ART \& BORDERS

En français

\section{Murs frontières et virtualité}

\section{Hélène Mutter}

Dans le cadre de la section spéciale Art \& Borders, l'artiste plasticienne Hélène Mutter interroge la perception des frontières étatiques par le biais de la post-photographie. Depuis l'accessibilité technologique de Google Earth, le flou des séparations entre les nations jurent avec l'appréciation physique et vécue du passage. On assiste à un aplatissement des réalités géopolitiques. L'artiste propose pour BIG_Review cet article inédit sur son projet photographique "Lines » qui avait été exposé au festival Fotolimo dont un article dédié est dans ce même numéro présenté.

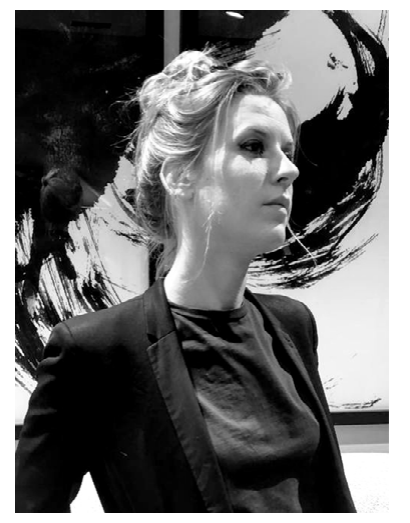

www.helenemutter.com

\section{A propos de l'artiste}

Artiste plasticienne, docteure en Art et Sciences de l'Art, chercheuse, Hélène Mutter soutient en 2020 sa thèse de doctorat intitulée "La guerre à l'épreuve de l'image-Art et dispositifs visuels ", réalisée en collaboration avec l'Académie Royale des Beaux-Arts et l'Université Libre de Bruxelles (ULB).

Sensible aux transformations politiques et sociales du monde qui nous entoure via une approche qui est celle de l'image au sens large, Hélène Mutter interroge les façons que nous avons de documenter le monde, et particulièrement les situations de crise et de conflit, par la création d'images, d'archives et de visuels, qu'ils soient produits par l'ingénierie militaire, des logiciels ou diffusés dans les médias.

Fin 2019, elle se rend au Liban alors en pleine révolution, afin d'y effectuer un projet photographique dans le cadre de sa résidence à la Beirut Art Residency. Son travail a récemment été publié dans la revue numérique Humanities, Arts and Society initiée par UNESCO-MOST, et elle est lauréate, en 2021, de la résidence artistique au Centre Culturel de Rencontre de Neimenster à Luxembourg.

Elle est également collaboratrice scientifique de la Faculté de Philosophie et Sciences Sociales de l'Université Libre de Bruxelles, laboratoire Repi (Recherche et Études en Politique Internationale). 
Borders in Globalization Review | Volume 3 | Issue 1 | Fall/Winter 2021

Mutter, "Murs frontières et virtualité"

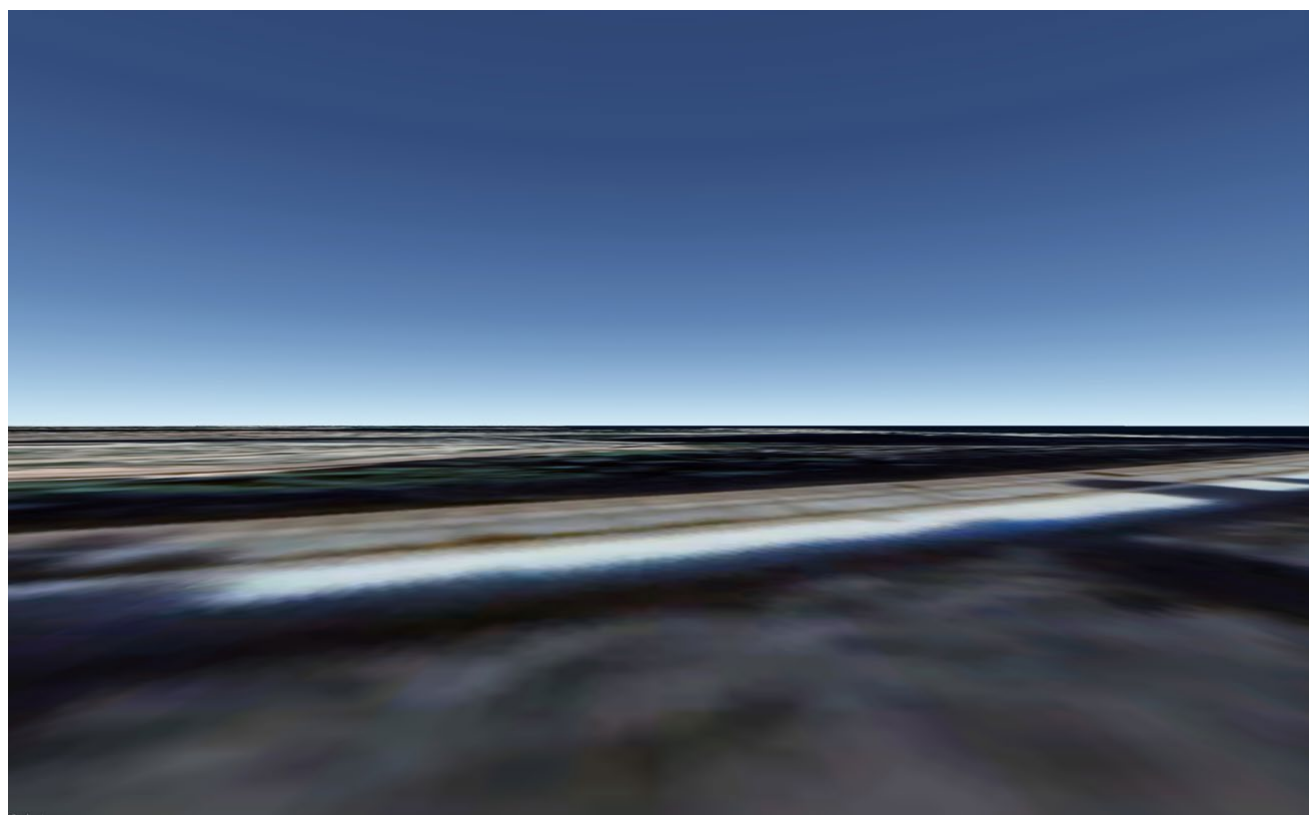

(C) 2018 Google

\section{Introduction}

De moins en moins vue au travers de sa fonction de représentation de la réalité, l'image photographique devient abstraite, non-figurative, un objet technique en lui-même et pour lui-même. Nous reviendrons, dans cette contribution, sur des questionnements précédemment soulevés dans mon travail de thèse qui a porté, à partir de l'analyse et de l'étude d'archives photographiques de la première guerre du Golfe de 1991, sur les différents régimes de visibilité mis à l'œuvre dans les représentations actuelles des conflits. Ma réflexion s'est portée sur les images produites au sein même de l'armée, afin de proposer une alternative visuelle face aux dangers liés à l'esthétisation des images de guerre. En opérant un décentrement du regard face à ces images, il s'est agi de penser en termes de "dé- subjectivation » où l'ensemble des dispositifs visuels mis en œuvre dans le cadre des conflits participe, de fait, à la dé-subjectivation du regard. Avec l'arrivée de la photographie sur le champ de bataille, c'est tout le champ de perception de la guerre qui se transforme. Questionner l'image produite dans le contexte de la guerre, c'est donc à la fois questionner son champ de perception et les différentes trajectoires de visibilité qui composent son environnement visuel. La guerre doit être pensée en lien avec notre regard. Depuis la guerre du Golfe, conflit qui a marqué une rupture dans la façon de penser et de représenter la guerre, le monde est devenu un écran géant sur lequel se succèdent, et de façon de plus en plus rapide, un flux et un flot d'images ininterrompus. L'image de guerre, telle qu'elle était pensée, montrée, imaginée jusque-là, n'allait plus jamais être la même. L'arrivée de la vue aérienne dans le champ de la guerre, la transformation du regard et l'abandon du corps produisent une image qui ouvre les limites visuelles auxquelles nous étions habitués jusqu'alors. La question du processus de production de l'image photographique soulève un questionnement qui n'est pas sans lien avec la dé-subjectivation à l'œuvre dans le champ de la guerre. L'opérateur placé derrière son appareil photo produit quelque chose " avec une machine », tout comme l'ingénierie militaire produit méthodiquement et logiquement sa propre imagerie. II s'agit alors de penser le renseignement et la reconnaissance aérienne militaire en termes de " globalisation de l'emploi de la puissance aérienne » (Aubout 2011, 89), où la guerre se pense aussi dans une troisième dimension.

Aujourd'hui, et accessible à tous, le logiciel Google Earth est devenu " l'œil du ciel », incarnant la figure contemporaine de la vision panoptique. En quelques clics, n'importe quel utilisateur se retrouve tel Icare survolant le monde, parcourant en une fraction de seconde, ou presque, la totalité du globe. C'est à partir d'un point de vue identique à cet œil absolu que le militaire, derrière son écran, aura droit de vie et de mort sur les populations. Selon cette perspective, nous pouvons affirmer que la logique de qui utilise Google Earth devient la même que celle développée par l'armée : n'importe qui peut survoler l'ensemble d'un territoire sans même s'en approcher, tout en étant en réalité situé à des milliers de kilomètres, derrière son écran d'ordinateur. 


\section{Dominer le monde}

La question de la distance, de la bonne distance, est une chose importante, à la fois pour voir, mais aussi pour toucher ou être touché. Tenir la distance permet d'un point de vue stratégique de dicter le rythme du combat tout en évitant de se faire toucher. Ni trop loin ni trop près. Dans les guerres napoléoniennes, on recommandait aux soldats de ne pas tirer avant de voir le blanc des yeux de l'adversaire. La distance s'est considérablement allongée depuis. Mais la violence de l'impact, elle, a peu changé. À travers les nouvelles technologies employées par les militaires via les dispositifs de prise de vue (drones, camérassuicides, images satellites), il est intéressant d'observer que l'articulation proximité/distance est au cœur même de la notion de combat. Qu'elle soit horizontale lors de déplacements latéraux ou frontaux entre des adversaires, ou verticale du point de vue d'une attaque aérienne, la distance multiplie les intervalles et l'espace qu'il reste à parcourir avant la frappe, l'impact. Dans la guerre qui en passe par les nouvelles technologies, le soldat derrière son écran de contrôle apparaít ici comme l'opérateur d'une guerre qui se joue aujourd'hui sans corps à corps. Les temps de l'assaut et du combat sont réduits à l'instant de la frappe de la cible, et la précision dite « chirurgicale » est censée provoquer des dégâts sans causer de dommages collatéraux. Dès lors, à quelle distance se situer ? À quel moment attaquer, abolir la distance qui sépare et/ou rapproche deux adversaires ? Cette violence maîtrisée, ritualisée, est bien synonyme de mort. "Le spectacle d'êtres humains luttant l'un contre l'autre, quelle qu'en soit la raison, est excessivement perturbant », écrit Joyce Carol Oates dans son ouvrage De la boxe. Avec vingt-cing siècles d'écart, nous voici devant une nouvelle application de l'art de la guerre : soumettre l'ennemi sans combat (Tzu
2008, 142) ? L'apparition de la reconnaissance aérienne sur le champ de bataille, puis de la photographie aérienne comme document d'expertise au sein du monde militaire participe, de fait, à ce changement d'échelle dans les stratégies modernes de combat. Médium profondément séduisant et toujours très présent dans notre imaginaire, les vues d'en haut engendrent des changements perceptifs considérables. La vue aérienne fait basculer notre regard d'Homme en un regard voulu objectif et neutre, transformant la surface terrestre en écran. En effet, l'espace visuel devient global et le regard souverain est absolu.

La vue aérienne, grâce aux technologies contemporaines, permet une approche globale des environnements dans lesquels nous vivons, transformant notre regard et la vision que nous avions du monde et construisant un espace désormais entièrement franchissable. Dans un monde moderne en pleine expansion urbanistique et au devenir machinique grandissant, les innovations visuelles sont nombreuses et il est question de « détecter un au-delà de la surface optique » (Frizot 2001, 387).

\section{À propos de Google Earth}

Depuis la première photographie de la Terre prise de l'espace datée au 24 octobre 1946 et la première image de la Terre en son entier véhiculée par la NASA en 1966, l'imagerie spatiale n'a cessé de se développer jusqu'à nous représenter la Terre comme un globe virtuel (Coulais $2015,175)$ sur notre ordinateur. Mais à partir des années 1960 et l'envoi du premier homme dans l'espace, c'est

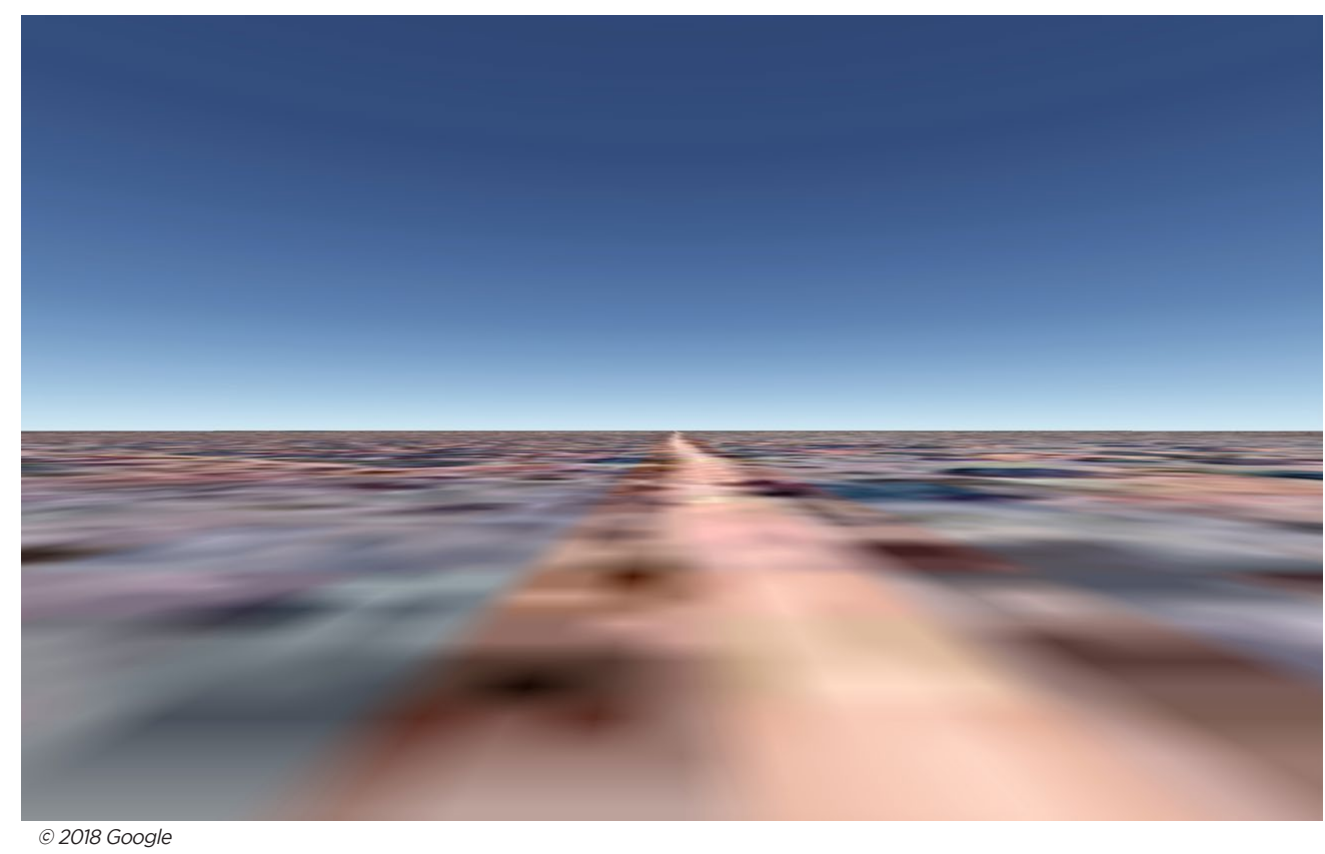


le regard de l'humanité sur le monde (Coulais 2015, 177) qui a été entièrement transformé. L'enjeu de ce type de représentations nécessite qu'aujourd'hui on les considère en tant qu'images qui font partie d'un dispositif visuel précis. L'utilisation militaire n'a de cesse de redéfinir cet espace de vision, car « ce nouveau régime de domination »(Deleuze 2018, 12) ${ }^{1}$ tel que l'a qualifié Gilles Deleuze, produit avant tout une suprématie stratégique. Hannah Arendt faisait part de son scepticisme quant aux progrès et aux politiques expansionnistes américaines en pleine guerre froide. Que devient l'homme en s'éloignant de la Terre ? La philosophe mettait en garde contre la fuite de l'homme face à sa condition, fuir « la terre pour l'univers » et fuir « le monde pour le Moi » (Arendt 1992, 39). ${ }^{2}$ Le premier aspect de cette analyse renvoie à la « conquête de l'espace » et à la volonté de l'homme d'atteindre le cosmos. Prenant comme exemple l'envoi d'un satellite en orbite en 1957, Arendt considère alors que le plus grand exploit de la science moderne est bien cette conquête de l'espace, mais qu'elle représente un véritable danger pour l'homme. Là où l'homme se voit conquérant de l'espace et du cosmos, se développe par corrélation une puissance et une domination techniques, annonciatrices de sa propre destruction.

Initialement, le logiciel Google Earth était connu sous le nom de «Earth Viewer » et commercialisé par la société Keyhole, dont le fond d'investissement In-Q-Tel était géré par la CIA. Aujourd'hui, qui mieux que Google peut symboliser le phénomène de globalisation et de contrôle ? Google Earth, I'un de ses logiciels gratuits les plus populaires, apparu en 2005, permet à tout utilisateur connecté à internet de parcourir le monde en quelques instants. Le message est clair : il est « le globe terrestre le plus détaillé au monde » (slogan en page d'accueil du logiciel : https://www.google. $\mathrm{fr} / \mathrm{intl} / \mathrm{fr} /$ earth/). Google Earth s'adresse à tout utilisateur en lui proposant, entre autres, les actions suivantes: " créez des histoires et des cartes », « trouvez un lieu qui vous plaît », « partez à l'aventure », « racontez votre histoire». Google Earth ou, traduit littéralement, Google Terre. J'emprunte ici l'explication que propose Marc Dorrian du mot Google dans son article "sur Google Earth », dans lequel il rappelle que Google tire son nom du mot gogol, nombre gargantuesque représenté par un nombre entier qui s'écrit avec le chiffre 1 suivi de 100 zéros. Google Earth ou « le gigantisme de la terre ».

« Si nous vivons, comme d'aucuns le prétendent, à l'âge de l'image aérienne, alors Google Earth en est l'un des principaux responsables. Aujourd'hui, la vue aérienne (l'image de partout) semble être partout, et on peut affirmer que Google Earth est sans doute la manifestation la plus importante et la plus stimulante de cet appétit contemporain et vorace pour les vues du ciel. De plus en plus, les relations au sol sont induites de manières complexes depuis le ciel ; une situation que Google Earth, grâce à la gigantesque disponibilité des images qu'il propose, a largement contribué à créer. Très appréciée pour ses effets spectaculaires et saisissants, la vue aérienne s'est véritablement imposée comme un élément récurrent de la culture visuelle populaire, des formes de supports et des installations touristiques » (Dorrian 2012, 230-231).

Comme le souligne ici l'auteur, il est vrai d'affirmer qu'aujourd'hui la vue aérienne est une imagerie qui fait partie intégrante de notre quotidien. Mais utilisée via l'interface Google Earth, elle constitue à mon sens un outil ludique et de distraction, dont l'unique finalité est de faire croire au spectateur qu'il est ce regard souverain et observateur sur le monde, qu'il est « un cyber-touriste »

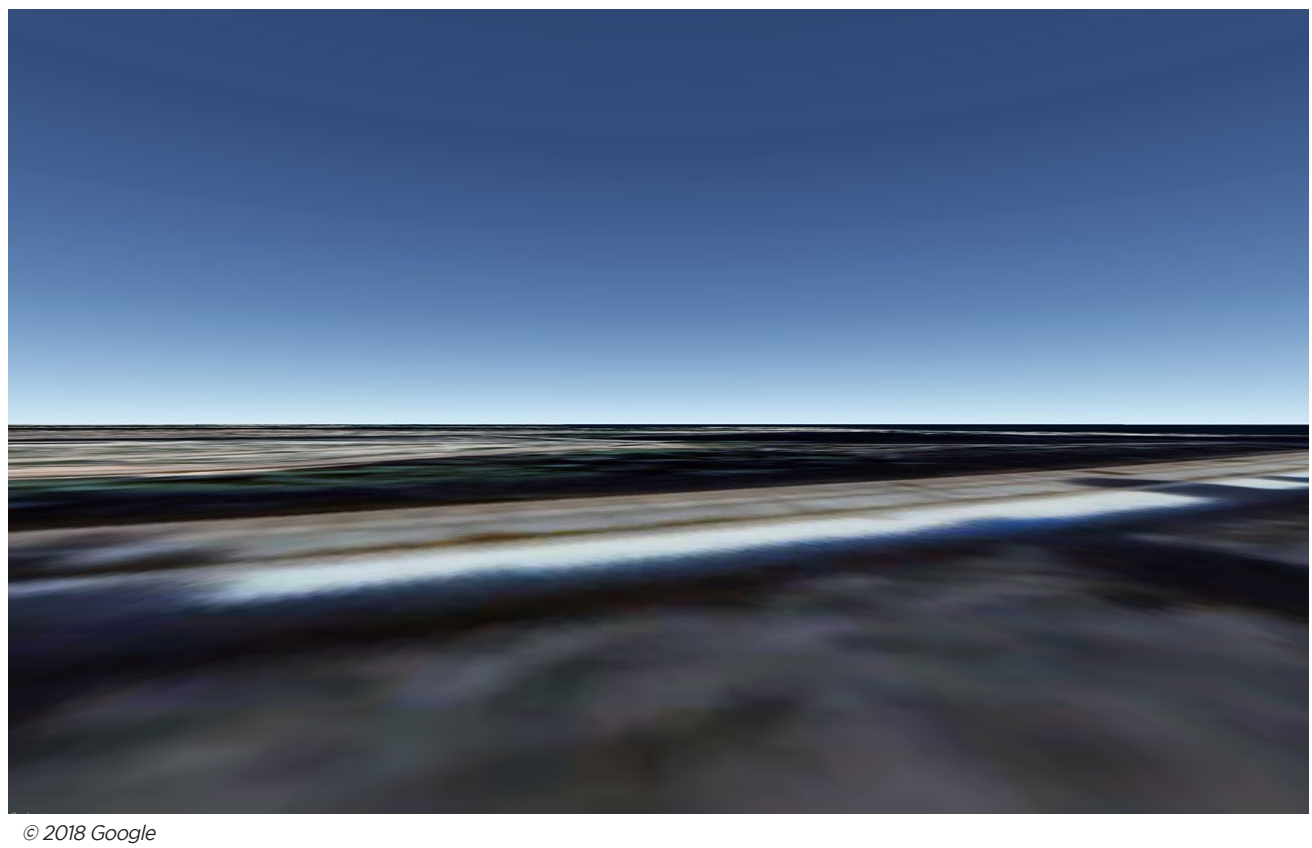




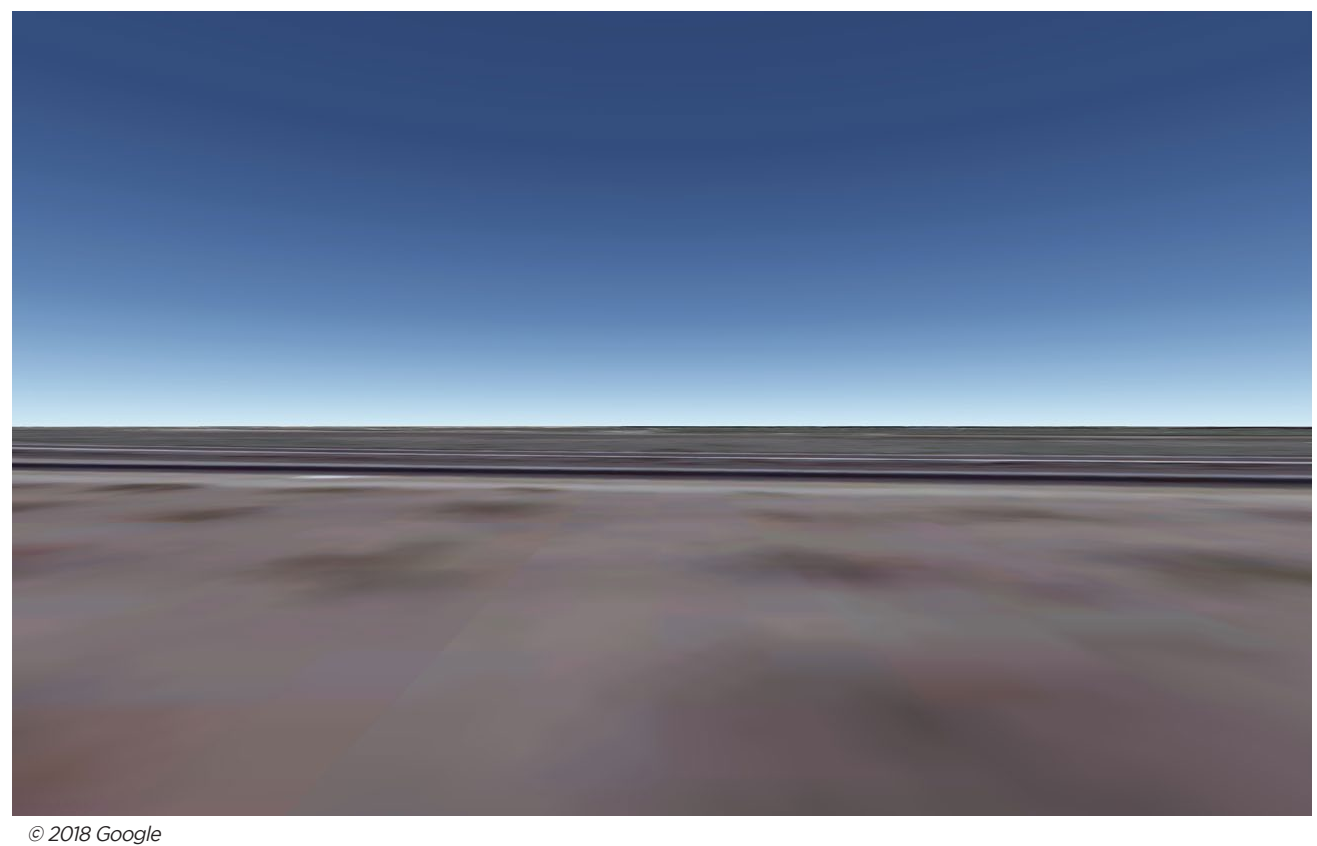

(Dorrian 2012, 232), comme le qualifie Dorrian. De fait, à la différence des images aériennes véhiculées au début du XXe siècle, que nous montrent les vues aériennes de Google Earth?

Lorsque nous naviguons dans le logiciel de Google, nous pouvons zoomer et dé-zoomer à l'infini sur le globe terrestre. Mais qu'est-ce qui apparaít, en premier lieu, lorsque nous ouvrons le logiciel ? Sur l'écran apparaít une petite main blanche, qui fait office de curseur spatial et qui nous permet de faire tourner la terre, un " simulacre numérique » (Dorrian 2012, 233) (d'ailleurs, en 2018, Google Maps a troqué son planisphère contre un globe terrestre en 3D), comme on ferait tourner un globe entre nos mains. Nous nous situons à une altitude de 11000 kilomètres environ, ne sachant pas très bien où nous sommes, flottant dans l'espace. À droite de l'écran, un curseur nous permet de zoomer et dé-zoomer sur le globe. Ce qu'il est intéressant de constater, c'est qu'à une altitude de 68 mètres, le point de vue vertical se redresse pour adopter le point de vue du piéton, « l'affichage au niveau du sol » comme indiqué sur l'écran.

«Google Earth nous présente une image dénuée de toute aura, dans laquelle le « magnifique joyau » des images d'apollo se trouve fragmenté (dans l'espace et dans le temps) en une panoplie d'ensembles de données géospatiales produites par les satellites en orbite et les dispositifs de capture d'image de capacité inférieure, pour être ensuite recousues numériquement, et pour enfin reconstituer l'image dans sa totalité » (Dorrian 2012, 234).

D'après l'analyse que propose Marc Dorrian des images véhiculées par l'interface du logiciel, on peut alors avancer l'affirmation suivante : la logique visuelle de Google Earth est la même que celle de la guerre depuis l'apparition des visuels de la première guerre du Golfe. En utilisant Google Earth, nous laissons libre cours à notre puissance d'immixtion dans le domaine tant public que privé tout comme l'avidité de la puissance militaire peut avoir accès au territoire qu'elle convoite. Par ailleurs, dans les deux cas, nous sommes face à une vision fragmentée de ce que nous voyons. Les images qui composent le globe terrestre proposées par Google Earth, telle une sphère éclatée en milliers de pixels et de strates visuelles, sont composées d'une multitude d'informations et de données qui sont elles-mêmes assemblées, reconstituées,

"recousues », afin de ne montrer qu'une infime partie d'un ensemble, à savoir l'image qui sera proposée au spectateur. Dans le champ visuel de la guerre et surtout dans les conflits contemporains, on peut constater un phénomène d'éclatement quant aux images diffusées et que l'on veut bien nous montrer des conflits. Tout comme les visuels de la guerre du Golfe sont devenus la surface de l'écran télévisuel, les images reconstituées deviennent la « surface numérique » (Dorrian 2012, 235) de Google.

\section{Des lignes frontières}

Mais avec des logiciels tels que Google Earth, peut-on aujourd'hui envisager la frontière comme un espace entièrement virtuel, dont les limites seraient elles-mêmes indéfinissables ? Étymologiquement, la frontière vient du provençal "fronteira », l'endroit où deux armées se font front, s'affrontent. L'histoire de la séparation des hommes par des murs semble donc être indissociable de la guerre, et il était à mon sens nécessaire de penser la représentation virtuelle des murs frontières à la lumière de la représentation de la guerre. C'est de cette réflexion que 
Borders in Globalization Review | Volume 3 | Issue 1 | Fall/Winter 2021

Mutter, "Murs frontières et virtualité"

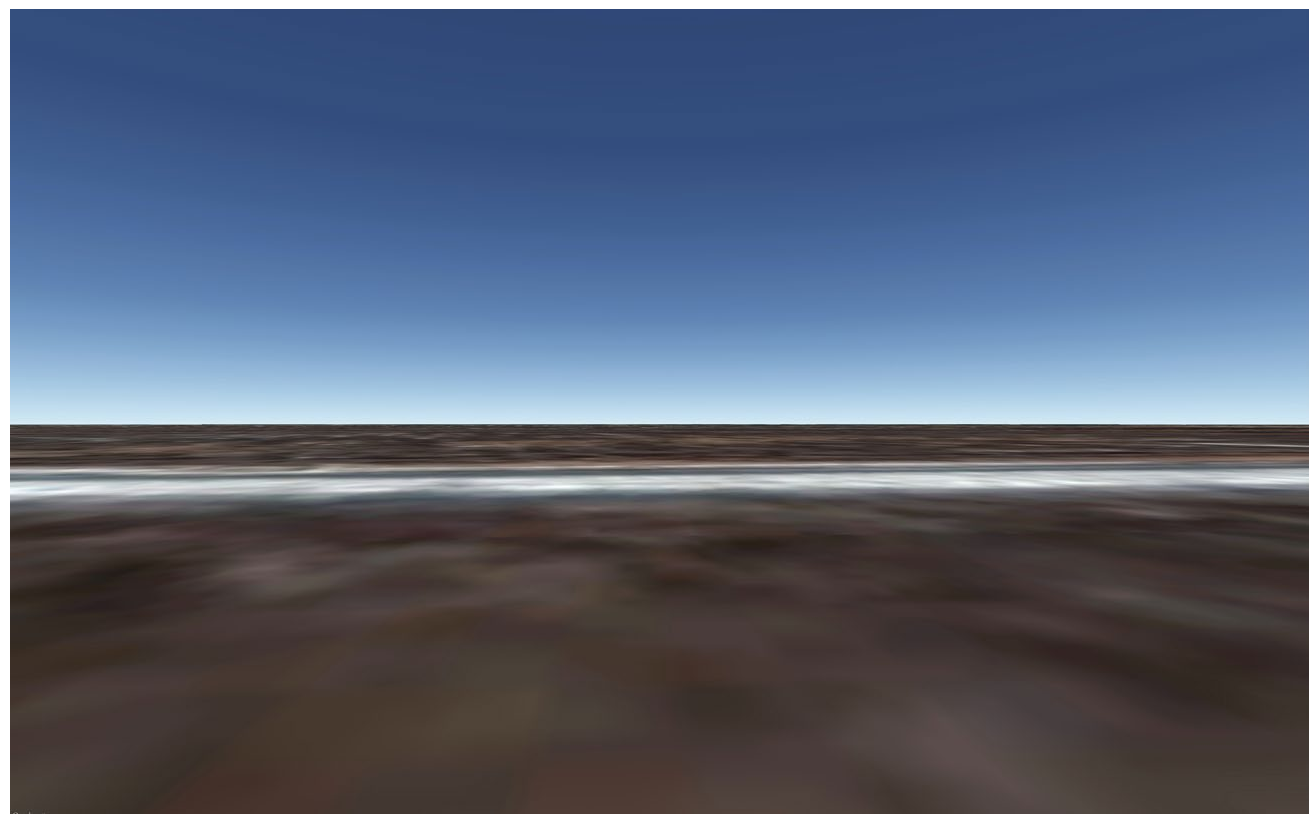

(c) 2018 Google

découle mon projet «Lines », qui a entièrement été réalisé sur le logiciel Google Earth, où j'ai recherché et archivé trente-neuf murs frontières qui existent encore aujourd'hui dans le monde sur la soixantaine déjà construits ou en cours de construction. Projet qui questionne l'ambiguité quant à la confrontation entre la réalité vue à travers un logiciel et la représentation virtuelle du réel, j'ai très vite été confrontée à la limite propre de la représentation des technologies numériques n'obtenant, pour seule représentation de murs, que des lignes abstraites. En faisant se rejoindre la ligne d'horizon et la ligne de la frontière, ces images produisent un éloignement continu de la frontière et de loin, elles semblent être un trait discontinu tout comme l'est le trait discontinu sur une carte.

Avec le point de vue du piéton, on se rend vite compte que l'image est très loin de la réalité : elle est entièrement virtuelle, pixellisée et standardisée. Seules changent, en fonction des régions du monde, la couleur des pixels utilisés, stylisation de plus qui tente de coller à la réalité. Bien loin des images aériennes satellitaires habituellement diffusées via Google Earth, on assiste à une simplification évidente du champ du réel : toutes les images se ressemblent et paraissent sortir du même jeu vidéo et notre œil semble s'être aujourd'hui habitué à une telle logique de production des images.

Les images de Google Earth sont intéressantes ici car on est dans une mise à distance totale de la frontière, qui se traduit également par une mise à distance des corps, qui sont inexistants. Ces images permettent de mettre à distance la réalité en brouillant les informations, elles ne coincident pas avec ce que l'on voit quotidiennement. Ce sont des images qui ne sont pas là pour informer, elles tiennent à distance l'observateur puisqu'elles ne signifient, en apparence, rien. Avec la multiplication des points de vue et des perspectives par la prolifération des modes de diffusion et de fabrication des images, il en va également de la multiplication des représentations de la frontière qui devient elle-même une représentation aléatoire. On sait dès lors quand elle commence, mais on ne sait pas où ni comment elle va finir.

\section{Liste des murs frontières représentés dans le projet « Lines » :}

- Afghanistan/Ouzbékistan

- Afrique du Sud/Mozambique

- Afrique du Sud/Zimbabwe

- Algérie/Maroc

- Bostwana/Zimbabwe

- Bulgarie/Turquie

- Espagne-Ceuta/Maroc

- Corée du Nord/Corée du Sud

- Egypte/Bande de Gaza

- France-Calais/Royaume-Uni

- Bande de Gaza/Israël

- Grèce/Turquie

- Inde/Bangladesh

- Inde/Birmanie

- Inde/Pakistan-Cachemire

- Irak/Turquie

- Iran/Pakistan

- Israël/Cisjordanie

- Israël/Egypte

- Israël/Liban

- Israël/Syrie

- Jordanie/Irak

- Kenya/Somalie

- Libye/Tunisie

- Macédoine/Grèce

- Malaisie/Thailande 
- Maroc/Sahara Occidental

- Espagne-Melilla/Maroc

- Mexique/Etats-Unis

- Oman/Emirats Arabes Unis

- Oman/Yémen

\section{Notes}

1. Article paru dans L'Autre journal $n^{\circ} 1$, mai 1990 , repris sous le titre "Post-scriptum sur les sociétés de contrôle » in Pourparlers. 1972-1990, éditions de Minuit, 1990, p. 247.

2. Traduction de The Human Condition, London, Chicago, University of Chicago Press, 1958 ; première traduction française en 1961, cité par Bernard Debbieux, « Les spatialités dans l'œuvre d'Hannah Arendt ", Cybergeo : European Journal of Geography [En línea], Epistemología, Historia de la Geografía, Didáctica, documento 672, Publicado el 02 abril 2014. https://doi.org/10.4000/ cybergeo.26277

\section{Works Cited}

Arendt, Hannah. 1992. Condition de l'homme moderne, Pocket, Paris.

Aubout, Mickaël. 2011. «Le milieu aérien, acteur et objet du renseignement », dans Hérodote, 1(140).

Coulais, Jean-François. 2015. Images virtuelles et horizons du regard, MetisPresses, VuesDensemble, Genève.

Deleuze, Gilles. 2018. "Les sociétés de contrôle », in EcoRev, n46, 2018(1). https://doi.org/10.3917/ecorev.046.0005

Dorrian, Marc. 2012. «Sur Google Earth », in Seize études pour une histoire culturelle: vues aériennes, sous la direction de Mark Dorrian et Frédéric Pousin, Metispresses, Genève.

Frizot, Michel. 2001. « Une autre photographie, les nouveaux points de vue », dans Nouvelle histoire de la photographie, sous la direction de Michel Frizot, Larousse, Paris.

Tzu, Sun. 2008. L'art de la guerre. Flammarion, Paris. 


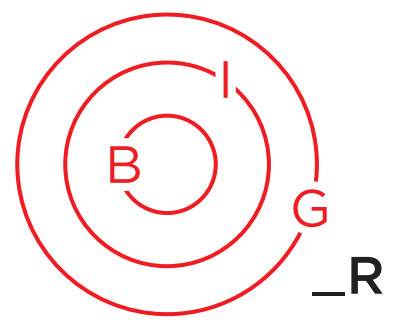

\section{ART \& BORDERS}

In English En français

\title{
Fotolimo: A Festival that Borders on all Images
}

\author{
Fotolimo, un festival qui fait \\ frontière de toutes images
}

\section{Christian Gattinoni}

In this BIG_Review exclusive for the sepcial section Art \& Borders, Christian Gattinoni highlights a conference given during the FOTOLIMO festival. Located on the FrenchCatalan border, the festival boasts "the mission to add energy to reflect on the concept of border through the image, in a critical cross-border perspective".

En exclusivité, pour notre section spéciale Art \& Borders de BIG_Review, Christian Gattinoni reflète l'une de ses conférences donnée lors du festival FOTOLIMO. Situé à la frontière franco-catalane, le festival a pour « mission d'ajouter de l'énergie pour réfléchir sur le concept de frontière à travers l'image, dans une perspective transfrontalière critique ».

\begin{abstract}
About the author
Teacher at the École Nationale Supérieure of Photography of Arles from 1989 to 2016. Christian Gattinoni has been practicing writing and photography since the mid-1970s. He works as an art criticmember of the International Association of the International Association of Art Critics (AICA)-mainly interested in the relationship between photography, other arts and human sciences whose common denominator remains the body. He shares his time between art criticism, curating exhibitions, and image pedagogy.
\end{abstract}

\section{A propos de l'auteur}

Enseignant à l'École Nationale Supérieure de la Photographie d'Arles de 1989 à 2016. Christian Gattinoni pratique écriture et photographie depuis le milieu des années 1970. II mène un travail de critique d'artmembre de l'Association Internationale des Critiques d'Art (AICA)-qui s'est principalement intéressé au rapport entre photographie, autres arts et sciences humaines dont le dénominateur commun reste le corps. II partage son temps entre la critique d'art, le commissariat d'exposition et la pédagogie de l'image.

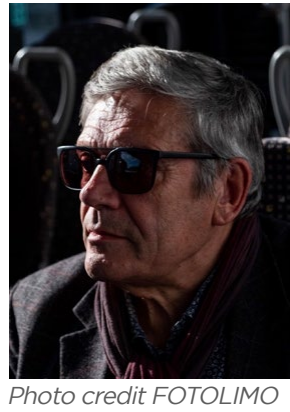

www.christiangattinoni.fr 


\section{Introduction}

Combining the term Foto, spelt more universally without the English or French "ph", and the term limo meaning "the limit", the creators of the Fotolimo festival span both sides of the French-Spanish border in the Pyrenean region, between Cerbère and Portbou. The first edition was founded in 2016 as a joint initiative between three associations in the Languedoc-Roussillon-Midi-Pyrénées region: the Lumière d'Encre association in the town of Céret, Negpos in Nîmes, and Phot'oeil in Talairan. The first two will continue alone in the second year.

If the border is defined as a geographical and territorial space where one swings from one side to the other, from one state to another, the people in charge of the festival want to approach it as "this territory of transgression, this immense place of sensitive and aesthetic potentiality. This open stage where innumerable scenarios can take place". In an even more positive way they envisage it, far from the English terms "boundary" or "border" which accentuate its character of limit, but as an interface, as a place producing exchanges. Wandering, nomadism, pilgrimage, invasion, exile, and colonization have constituted the history of humanity into a history of migration. The political, ideological, and artistic stakes involved justify the urgency they feel to make a frontier, which originally entailed going into battle to fight and defend oneself. Photography and other contemporary art forms serve as the weapons for those participating in Fotolima. This essay briefly illustrates these themes with glimpses of the diverse works showcased at the festival's premier event.

\section{The Physical Limits of the Border}

Several artistic contributions to the festival explore the physical limits of the border. The Belgian artist Hélène Mutter has photographed in digital color intermediate places in almost forty countries at war where borders are indistinct or contested and often represent the very source of the conflict. Her Lines series [discussed in an essay by the artist in this issue] results in a set of quasiabstract images that show the limits of visual geography.

Maxime Taillez, having lived in the North of France, went back and forth to Belgium while he studied photography at Le 75, an Art School in Brussels. His work scans the no-man's lands around the old customs posts between the two countries in search of the facts of tourism in the duty-free commercial zones. In the process, he denounces the randomness of the border.

Arno Brignon received a grant for documentary photography from the French Ministry of Culture for his project Freedoors to Spain [Figure 1], whose work was first exhibited at a festival in Ceuta, a Spanish city adjoining Morocco. With the only line of escape the rock of Gibraltar, on a small territory of 20 square kilometres,

\section{Introduction}

En associant le terme Foto, orthographié plus universellement sans le « ph » anglais ou français, et le terme limo signifiant " la limite »; les créateurs du festival Fotolimo s'étendent de part et d'autre de la frontière franco-espagnole pyrénéenne, entre Cerbère et Portbou. La première édition a été fondée en 2016 comme initiative conjointe entre trois structures de la région Languedoc-Roussillon-Midi-Pyrénées : Lumière d'Encre à Céret, Negpos de Nîmes et Phot'œil de Talairan. Les deux premières continueront seules la deuxième année.

Si la frontière se définit comme un espace géographique et territorial où l'on bascule d'un côté ou de l'autre, d'un Etat à un autre, les responsables du festival veulent l'aborder comme " ce territoire de transgression, cet immense lieu de potentialité sensible et esthétique. Cette scène ouverte où peuvent d'innombrables scénarios peuvent se dérouler». De manière encore plus positive ils l'envisagent, loin des termes anglais de « boundary » ou de « border » qui accentuent son caractère de limite, mais comme une interface, comme un lieu producteur d'échanges. Les errances, le nomadisme, les pèlerinages, les invasions, l'exil et la colonisation ont transformé l'histoire de l'Humanité en une histoire de migration. Les enjeux politiques, idéologiques, et artistiques justifient l'urgence qu'l y a à faire de la frontière, qui à l'origine n'existait pas, une frontière. De faire une frontière, ce qui à l'origine signifiait aller au combat pour se battre et se défendre. La photographie et d'autres formes d'art contemporain servent d'armes pour ceux qui participent à la Fotolimo. Ces thèmes sont brièvement illustrés par des aperçus des différentes œuvres présentées lors du festival.

\section{Les limites physiques de la frontière}

Plusieurs contributions artistiques au festival explorent les limites physiques de la frontière. L'artiste belge Hélène Mutter a photographié en couleur numérique des lieux intermédiaires dans près de quarante pays en guerre où les frontières sont indistinctes ou contestées et représentent souvent la source même du conflit. Sa série Lines [voir l'article de l'artiste dans ce numéro] aboutit à un ensemble d'images quasi abstraites qui montrent les limites de la géographie visuelle.

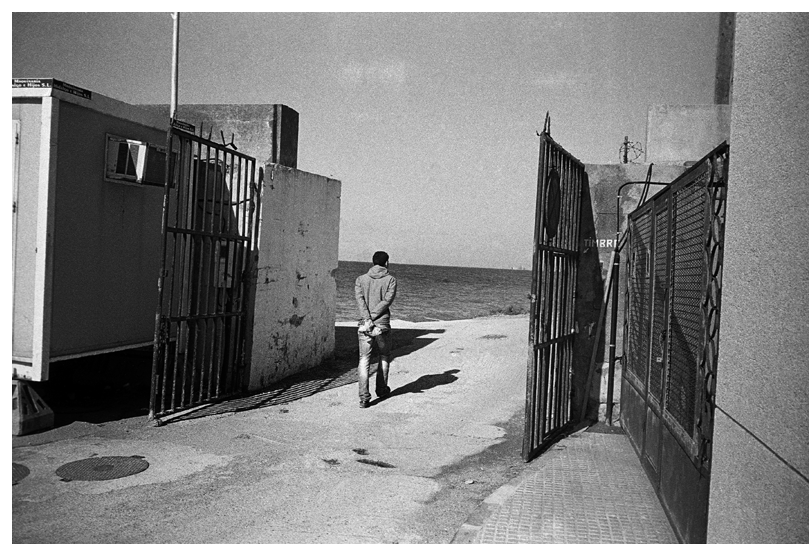

Figure 1. Freedoors to Spain. (c) Arno Brignon. Courtesy of the artist and Fotolimo. 
migrants, Moroccans, and Spaniards seem to be blocked. The author disowns the situation as follows:

In these places, consumerism is pushed to its caricature. Questionable financial products, tax havens, speculative bubbles, controversial diplomatic relations, more or less legal trafficking have made and still make the wealth of these territories. In atmospheric black and white shots, intimate spaces, places of passage and thresholds organize centrifugal visions.

Daphne Le Sergent created in 2010 an eight-minute video: 24 clichés que j'ai occupés (24 Pictures I Took) [Figure 2]. They were collected in the south of Spain, in the region of Almeria. "El mare del plastico" is made up of 17,000 hectares of greenhouse crops whose spectacular development is based on the overexploitation of immigrant labor. Black and white photos are superimposed with color-video inlays. Each one is introduced by simple actions: arriving, phoning, walking, waiting, getting off, living, working, looking. The notion of border is materialized by the juxtaposition of the fixed image and the moving image of the same place in the same space.

\section{The Issue of Migration}

Je suis pas mort je suis là ( I am not Dead I am Here) was produced by Laetitia Tura during stays in Morocco and Tunisia to meet migrants who shared their experiences of migratory journey.

For these migrants to Italy another stage is the Greek port city of Patras, here studied by Stephanos Mangriotis in Europa Inch Allah (Europe Godwilling) [Figure 3].

For Les traverses (The Crossbars) Aglaé Bory brings together two sets: Mers intérieures (Inland Seas) which aligns men and women with their backs to the sea, and Les invisibles (The Invisibles), which reveals their faces [Figure 4]. In the same way, the most sensitive images of Border Line by Richard Petit [Figure 5], produced during his residency at Lumière d'encre, are these deliberately blurred alignments of male bodies that

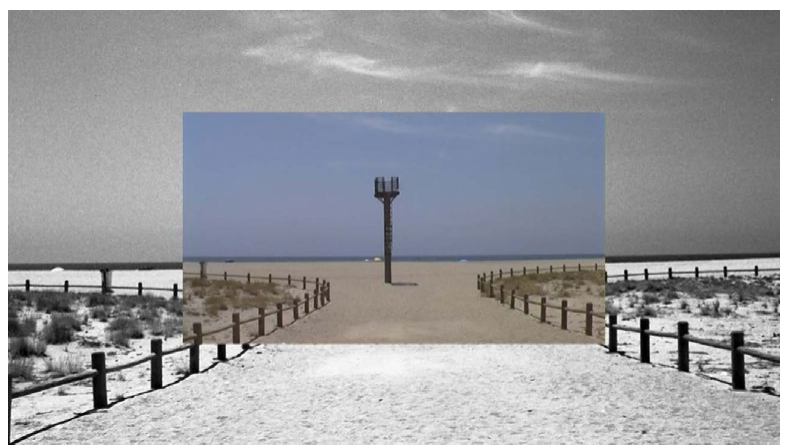

Figure 2. 24 clichés que j’ai occupés. ( Daphné Le Sergent. Courtesy of the artist and Fotolimo.
Maxime Taillez, ayant vécu dans le Nord de la France a beaucoup pratiqué les allers-retours vers la Belgique jusqu'à faire ses études à l'école de photographie « le 75 » à Bruxelles. II scrute les no-man's lands autour des anciens postes de douane entre les deux pays en recherche des faits de tourisme dans les zones commerciales hors taxes. II dénonce ainsi l'aléatoire de la frontière.

Arno Brignon a reçu une Bourse à la photographie Documentaire du Ministère de la Culture pour son projet Freedoors to Spain [Figure 1], dont la première œuvre a été exposée pour la première fois au festival de Ceuta, la ville espagnole située dans le Maroc voisin. Sur un territoire restreint de 20 kilomètres carrés, Migrants, Marocains et Espagnols semblent bloqués avec pour seul ligne de fuite le rocher de Gibraltar. L'auteur en dénonce la situation ainsi :

Dans ces lieux, la société de consommation est poussée à sa caricature. Produits financiers douteux, paradis fiscaux, bulles spéculatives, relations diplomatiques controversées, trafics plus ou moins légaux ont fait et font toujours la richesse de ces territoires. Dans des clichés atmosphériques en noir et blanc, espaces intimes, lieux de passages et seuils organisent des visions centrifuges.

Daphné Le Sergent crée en 2010 une vidéo de huit minutes : 24 clichés que j'ai occupés [Figure 2]. Clichés qui ont été recueillis dans le Sud de l'Espagne, dans la région d'Almeria, « El mare del plastico » est constituée par 17000 hectares de cultures sous serres dont le développement spectaculaire repose sur la surexploitation de la main d'œuvre immigrée. Ces clichés en noir et blanc sont superposées avec des incrustations de vidéo couleur. Chacune est introduite par des actions simples « Arriver, téléphoner, marcher, attendre, descendre, habiter, travailler, regarder ». La notion de frontière est matérialisée par la juxtaposition entre image fixe / image mouvante d'un même lieu.

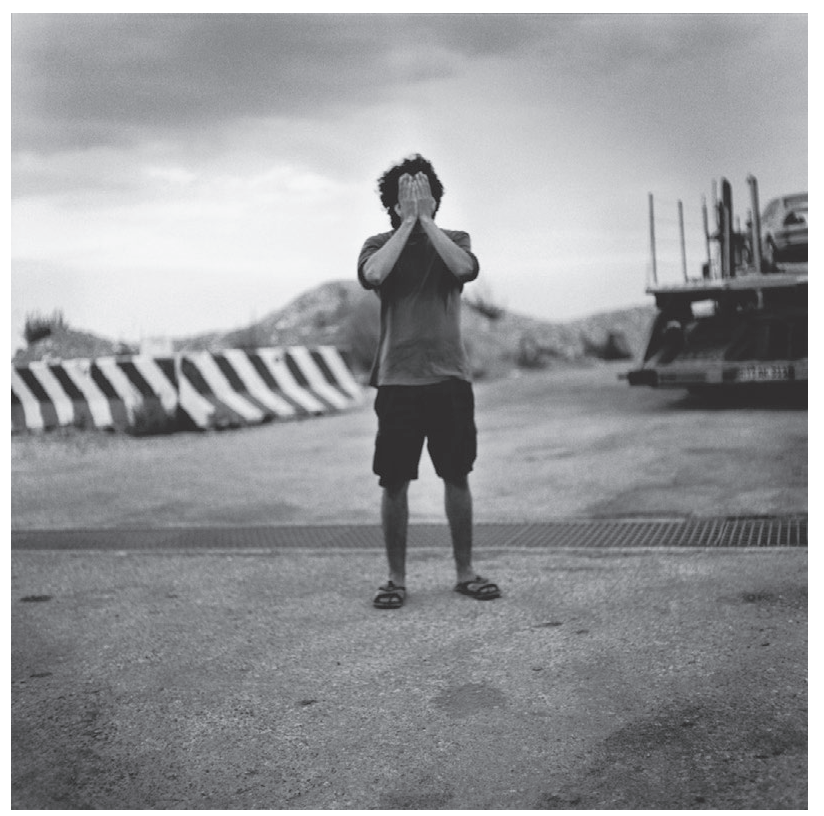

Figure 3. Europa Inch Allah. (c) Stephanos Mangriotis. Courtesy of the artist and Fotolimo. 


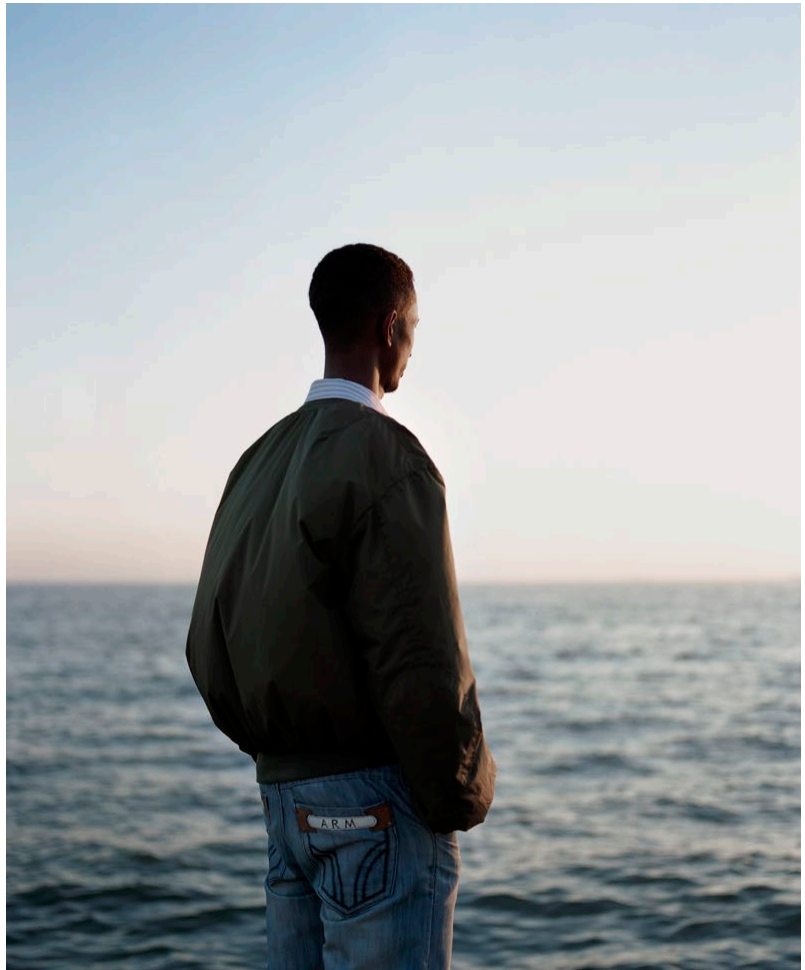

Figure 4. Les traversées. (c) Aglaé Bo. Courtesy of the artist and Fotolimo.

make us aware of all the migrants who disappear from our daily screens while trying to cross borders at the risk of their lives. At the edge of the shore or in the depths of the forest, the ghostly views of these shipwrecked people are deeply moving, between fact and fiction.

Jacqueline Salmon produced Le hangar (The Warehouse) on the accommodation sites of Sangatte. Following Paul Virilio's book Chambres précaires (Precarious Rooms) from "Samu social" in Paris. She testifies to the living conditions of migrants by using only the materials available to them: UN camp style tents, algeco shelters, folding beds, khaki blankets, and mixtures of government-issued civilian and military fabrics. Conversely, Thierry Dana for his series El Hogar (Home) shows the daily needs of an Afghan refugee family at last appeased in Geneva.

In a more experimental way, Francesca di Bonito studies these Migrations [Figure 6] through the biological cycles of the living bodies and the displacements of population as social bodies which are thus caught in the same movement.

Ronny Trocker produced his animated film Estate based on the famous photo by Juan Medina showing an African emigrant emerging from the water exhausted and walking on all fours on a beach where indifferent tourists are lounging. The cliché published in the press finds a second life which accentuates its scandalous character.

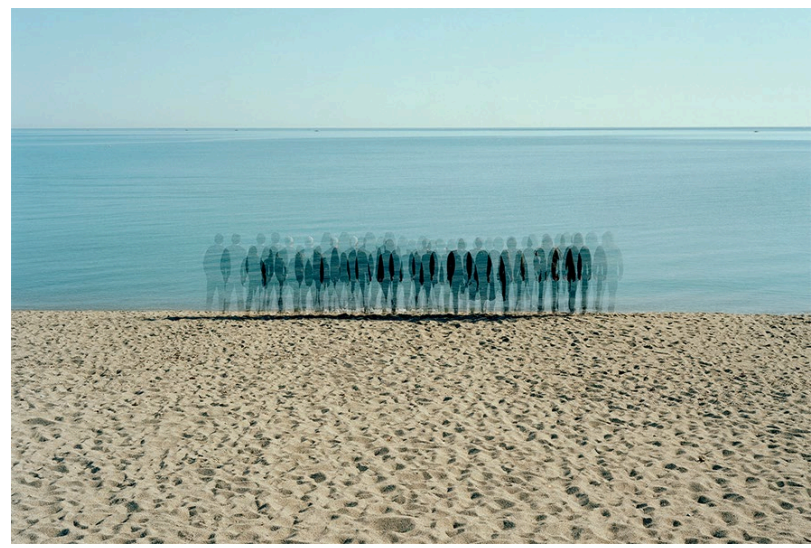

Figure 5. Border Line. (c) Richard Petit. Courtesy of the artist and Fotolimo.

\section{La question des migrations}

Je suis pas mort je suis là a été produit par Laetitia Tura lors de séjours au Maroc et en Tunisie à la rencontre de migrants qui partagent leur expérience migratoire.

Une autre étape, celle de la ville portuaire de Patras en Grèce pour ces migrants vers l'Italie, est étudiée par Stephanos Mangriotis dans Europa Inch Allah [Figure 3].

Aglaé Bory réunit pour Les traversées deux ensembles : Mers intérieures aligne hommes ou femmes de dos, face à la mer, tandis que Les invisibles révèlent leurs visages. [Figure 4] De même les images les plus sensibles de Border Line de Richard Petit, [Figure 5] réalisées en résidence à Lumière d'Encre, sont ces alignements volontairement flous de corps masculins qui nous sensibilisent à tous ces migrants qui disparaissent de nos écrans quotidiens en tentant au risque de leur vie de franchir les frontières. Au bord du rivage ou dans les profondeurs de la forêt, les vues fantômes de ces naufragés sont bouleversantes, entre document et fiction.

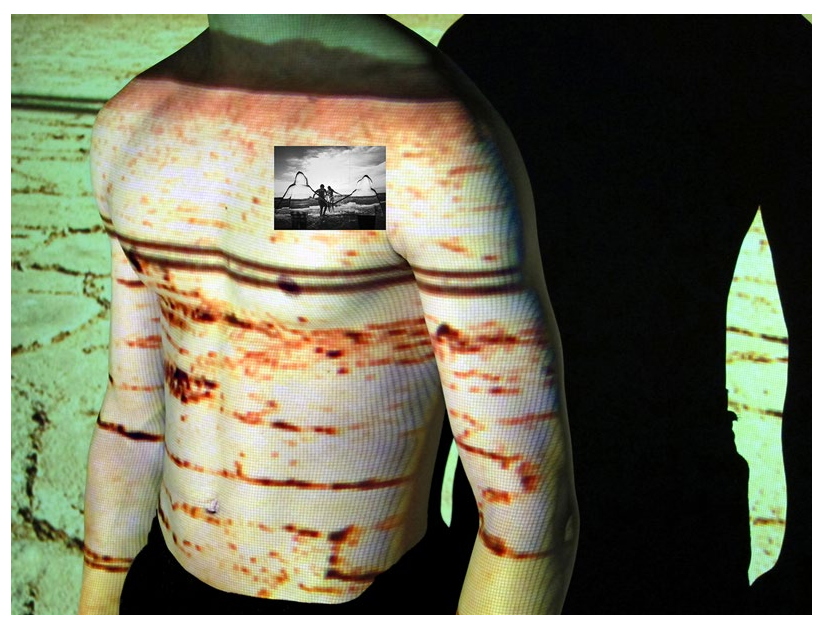

Figure 6. Migrations. (c) Francesca di Bonito. Courtesy of the artist and Fotolimo. 


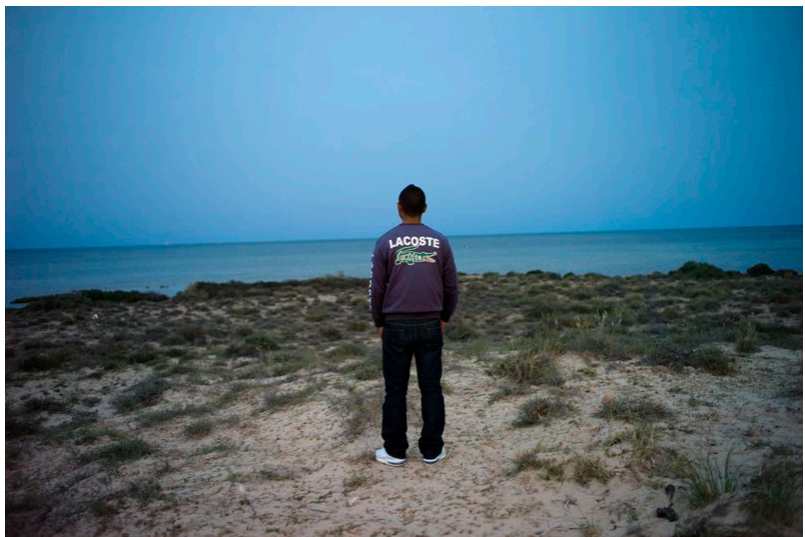

Figure 7. Mare Mater. (c) Patrick Zachmann. Courtesy of the artist and Fotolimo

Patrick Zachmann produced a 52-minute video Mare Mater, made between 2009 and 2013 [Figure 7]. Between diary and documentary, he goes in search of the origins of his Jewish family from Algeria that he compares to the destinies he encountered of "migrants leaving their countries on the southern shore of the Mediterranean, fleeing unemployment, dictatorship and lack of future. The dream of a Europe that will never be as beautiful, as welcoming, as rich as seen from the other side".

\section{Communities}

Not wanting to be satisfied with the sole question of migrants, the people in charge of the festival open their concerns to the definition in images of different communities. Hence various returns on recent history.

In order to give an account of this lost territory that East Germany has become, Leila Danerol has equipped herself with an old medium format silver camera "made in USSR". [Figure 8]. This contemporary tool of the historical situation that ended in 1990 allows her to visually render the traces of this disappeared territory.

Anne Leroy focuses on Abkhazia, an independent territory since 1992 that stretches from the shores of the Black Sea to the mountains of the "Great Caucasus" and shares border areas with Russia and Georgia.

Anna Puig Rosado, a descendant of Jewish grandparents from Odessa and Istanbul, says she has observed Israel from Syria, Jordan, and Egypt. For Escape, Tel Aviv she focuses on the walls, their posters and slogans.

Two creators give an unclichéd version of the Traveler community. First, Hortense Soichet created Esperem by initiating gypsy women from the Carcassonne region to photography over several years. These workshops organized by the GRAPh have resulted in an edition and a traveling exhibition. Then, the Catalan Neus Sola shows with Dolls the daily life of young gypsies. In 2020 she joined the Fotolimo organization with her aladeriva lab that she runs with David
Jacqueline Salmon a produit Le hangar sur les sites d'hébergement de Sangatte. En suivant le livre Chambres précaires de Paul Virilio sur le Samu social à Paris, elle témoigne des conditions de vie des migrants à travers le seul matériel : des tentes de type camp onusien, des abris algeco, des lits pliants, modèles civils et militaires confondus; des couvertures kaki... A l'opposé Thierry Dana pour sa série El Hogar montre le quotidien enfin apaisé d'une famille afghane réfugiée à Genève.

De façon plus expérimentale Francesca di Bonito étudie ces Migrations [Figure 6] à travers les cycles biologiques des corps vivants et les déplacements de populations en tant que corps sociaux qui se retrouvent ainsi pris dans un même mouvement.

Ronny Trocker a produit son film d'animation Estate d'après la célèbre photo de Juan Medina montrant un émigré africain sortant de l'eau épuisé et avançant à quatre pattes sur une plage où se prélassent des touristes indifférents. Le cliché paru dans la presse retrouve une seconde vie qui en accentue le caractère scandaleux.

Patrick Zachmann produit Mare Materune vidéo de 52 minutes dont la réalisation a duré de 2009 à 2013. [Figure 7] Entre journal intime et document, il part à la recherche des origines de sa famille juive d'Algérie qu'il croise avec ces destinées rencontrées « des migrants quittant leur pays de la rive sud de la Méditerranée, fuyant le chômage, la dictature et l'absence d'avenir... Le rêve d'une Europe qui ne sera jamais aussi belle, aussi accueillante, aussi riche que vue de l'autre côté. »

\section{Communautés}

Ne voulant se contenter de la seule question des migrants, les responsables du festival ouvrent leurs préoccupations

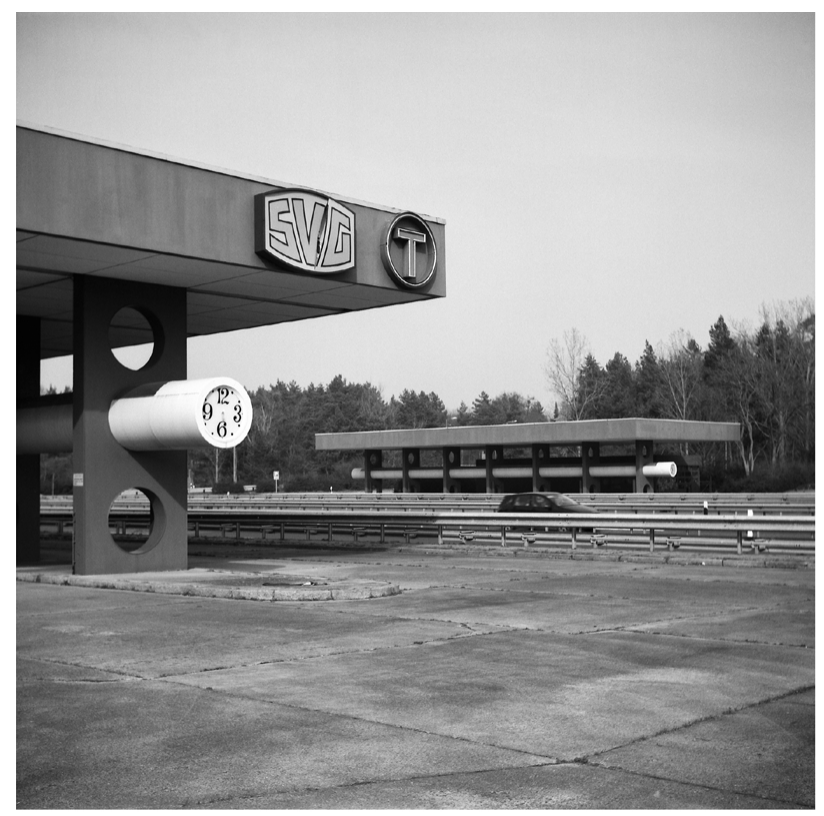

Figure 8. Territoire égaré. (c) Leila Danerol. Courtesy of the artist and Fotolimo. 
Del Campo. Following studies in humanities, art, and image therapy, she engages in participatory photography projects.

David del Campo bears witness to the pre-Islamic Yazidi minority refugees in Kurdistan. On August 3, 2014, the Islamic State committed the last of 74 genocides against this community. He photographed their modest tents where they inscribed 3/8 in memory of these facts and the smartphone screenshots where they inform their families about their precariousness on social networks and get informed in return.

\section{The Borders of Gender}

Patrice Loubon and Patric Clanet, who are in charge of the NegPos Center for Photographic Art, are attentive to the creation in Latin America and have therefore exhibited several representatives in Nîmes. From a well-established documentary tradition, photography in Cuba has found its own place in artistic education, where the Higher Institute of Art (ISA) is particularly active. For Fotolimo, they have chosen creators who focus on another type of border, more intimate that of gender, sexual identity, and the transgressions that are attached to it.

The Cubans, Yuri Obregon Batard in a serial approach raises the signs of Cubanity in all its excesses, and Alejandro Pérez Alvarez works in a color documentary vein. In his series El Silencio del Cuerpo (The Silence of the Body), he invites us to discover with modesty and respectful distance the world of transgenders in Cuba [Figure 9]. As for Yomer Montejo Harrys, he uses X-rays to illustrate some of the thorniest issues of this society in Havana, which has many problems including: the desire to leave, prostitution, and bureaucracy. The Chilean Carla Yovane Pérez gives a personal vision, soft and intimate, of Chilean male prostitutes.

As for the canons of femininity, they are staged by Noncedo Gxekwa from Johannesburg. She claims a distanced studio aesthetic close to fashion, while another Chilean, Zaida González Ríos, mixes in her self-staging the cycles of life and death, realism and mysticism, colorization and kitsch, in the service of a very virulent social criticism, in a provocative and liberating outrage that challenges the clichés of femininity. The French Fabien Dupoux takes advantage of a Chinese opera he observed in Laos in 2015 to show how open can be the Southeast Asian societies towards homosexuality and trans-identity.

\section{Conceptualization}

The first round table in 2017 brought together Gregory Tuban, a geographer who looks back at the borders of the Third Republic, a historian, Guillaume Lacquement, who looks back at the geography of the inter-German border [Figure 10] and Mathilde Pette, a sociologist who comments on contemporary migratory flows from

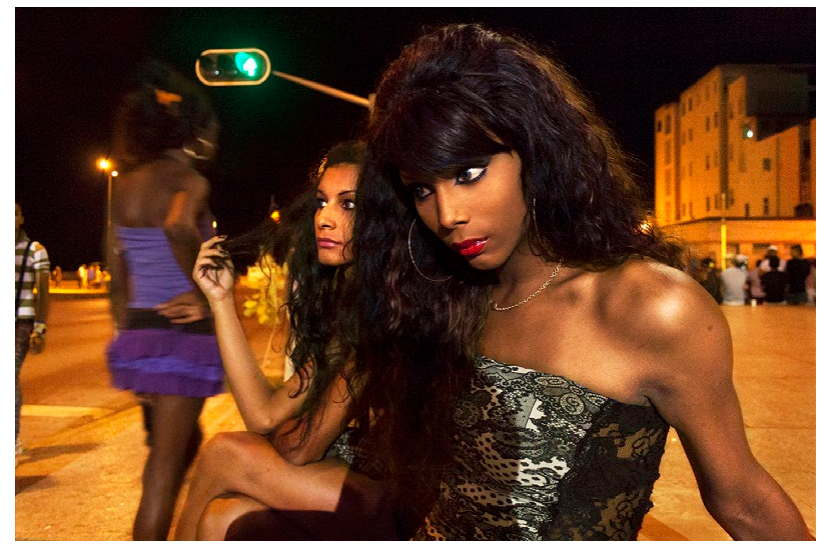

Figure 9. El silencio del cuerpo. (c) Alejandro Pérez Alvarez. Courtesy of the artist and Fotolimo.

à la définition en images de différentes communautés. D'où divers retours sur l'histoire récente.

Leila Danerol pour rendre compte de ce Territoire égaré qu'est devenu l'Allemagne de l'Est s'équipe d'un vieil appareil photographique argentique, moyen format, " made in USSR » [Figure 8]. Cet outil contemporain de la situation historique ayant pris fin en 1990 lui permet de rendre compte visuellement des traces de ce territoire disparu.

Anne Leroy s'attache quant à elle à l'Abkhazie, un territoire indépendant depuis 1992 qui s'étend des bords de la mer Noire aux montagnes du " grand Caucase » et partage des zones frontalières avec la Russie et la Géorgie.

Anna Puig Rosado descendante de grands parents juifs d'Odessa et Istanbul dit avoir observé Israël depuis la Syrie, la Jordanie et l'Egypte. Pour Escape, Tel Aviv elle s'attache à en montrer les murs, leurs affiches et leurs slogans.

Deux créatrices donnent une version non clichée de la communauté des gens du voyage. Hortense Soichet a créé Esperem en initiant sur plusieurs années des femmes gitanes de la région de Carcassonne à la photographie. Ces workshops organisés par le GRAPh ont abouti à une édition et à une exposition itinérante

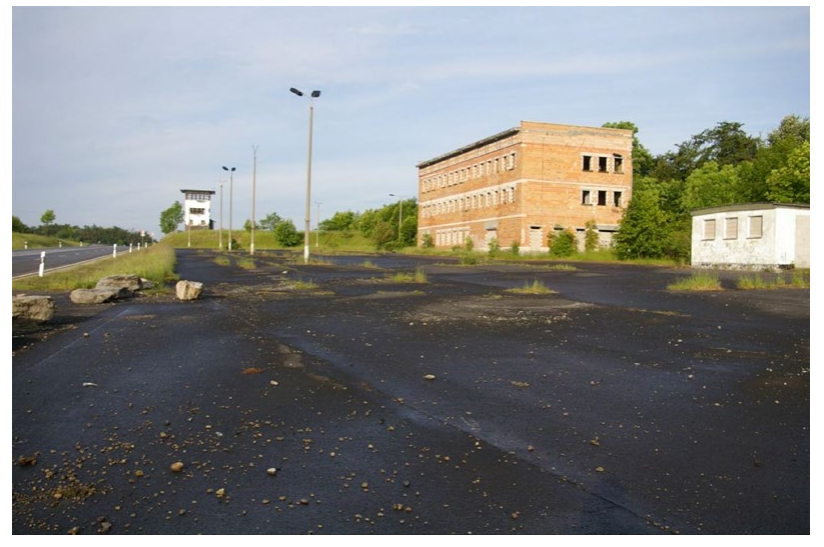

Figure 10. Ancien poste frontière interallemand entre la Thuringe et la Bavière. (c) Guillaume Lacquement. Courtesy of the artist and Fotolimo. 
Calais in particular, from the point of view of the human sciences. In 2019 the floor is given to Claire Rodier, author of Xenophobia Business, published by La découverte, where she analyzes the global market of security increasingly privatized, securing borders (surveillance devices and the computerization of visas and passports) to the management of detention centers and the escort of deportees.

\section{Various Techniques and Aesthetics}

In 2020, I was invited by Patric Clanet, who was in charge of the research pole of Fotolimo and Pilar Parcerisas, Director of the Summer School Walter Benjamin CerbèrePortbou, and partner of the Festival for the previous two years, to present at a conference. and roundtable. I entitled it: De la photographie des frontières aux frontières de la photographie (From the Photography of Borders to the Borders of Photography). Apart from my own critical interests I was prompted by the diversity of techniques and aesthetics exhibited.

A graphic designer from Montpellier proposes under the label Débit de Beau her collages as photo-trafics for so many symbolic fights. Camille Carbonaro edits personal archives for her work Appelle moi Victoria (Call Me Victoria) in search of her Italian roots. Jan Lemitz uses Google views to scrutinize his Innocent Passages. Manuel Benchetrit photographs the posters of architectural projects to duplicate L'épiderme de la ville (The Epidermis of the City). Salvatore Puglia reactivates a letter of Hölderlin in a photo-text series that manages his Transit in a photographic road-movie. Caitriona Dunnett treats the border with the archaic process of the cyanotype that makes the Irish Mass Paths more present. Francesca di Bonito exhibits her reliquaries made from anonymous web archives embedded in shells. The performative practice of the Chinese artist Ning Zuohong sees him proceeding to the installation of a red thread as a symbolic link in the trans-border landscapes.

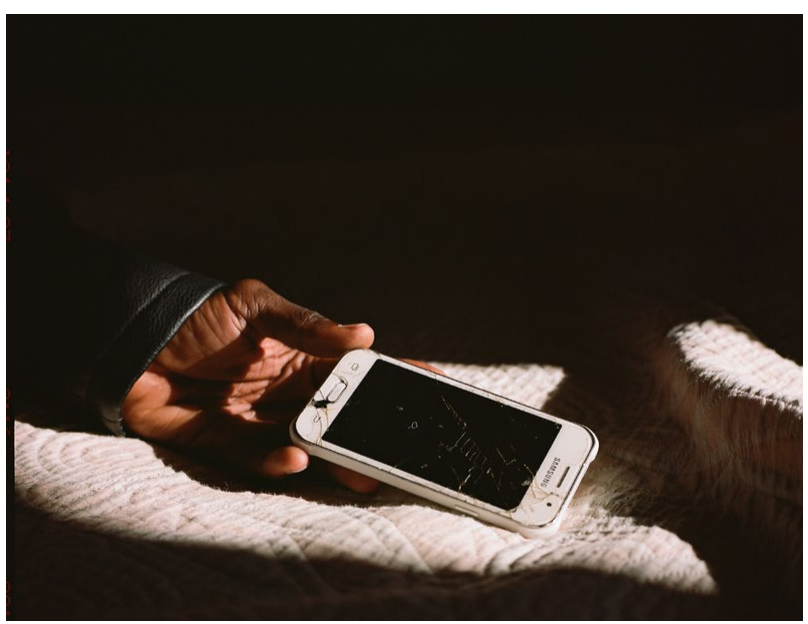

Figure 11. Notre affaire est de passer en traçant des chemins sur la mer (c) Laetitia Tura. Courtesy of the artist and Fotolimo.
La catalane Neus Sola montre avec Poupées le quotidien de jeunes gitanes. En 2020, elle a rejoint l'organisation de Fotolimo avec son laboratoire aladeriva qu'elle dirige avec David Del Campo. Suite à des études de sciences humaines, d'art et de thérapie par l'image, elle engage des projets de photographie participative.

David del Campo témoigne de la minorité préislamique Yazidi réfugiés au Kurdistan. Le 3 août 2014, l'État islamique a commis le dernier des 74 génocides dont a été victime cette communauté. II a photographié leurs modestes tentes où ils ont inscrit $3 / 8$ en mémoire de ces faits et les captures d'écran de smartphone où ils informent de leur précarité sur les réseaux sociaux.

\section{Les frontières du genre}

Patrice Loubon et Patric Clanet, responsables du Centre d'art photographique NegPos, sont attentifs à la création en Amérique latine et de ce fait ils en ont exposé plusieurs représentants à Nîmes. A partir d'une tradition documentaire bien ancrée, la photographie a trouvé à Cuba sa part propre dans l'enseignement artistique où l'Institut Supérieur d'Art (ISA) est particulièrement actif. Pour Fotolimo ils ont choisi des créateurs s'attachant à un autre type de frontière, plus intérieure, celle du genre, de l'identité sexuelle et des transgressions qui y sont attachées.

Les cubains, Yuri Obregon Batard dans une approche sérielle relève les signes de la cubanité dans toutes ses outrances, et Alejandro Pérez Alvarez travaille dans une veine documentaire couleur. Dans sa série El Silencio del Cuerpo, il nous invite à découvrir avec pudeur et distance respectueuse le monde du transgenre à Cuba [Figure 9]. Quant à Yomer Montejo Harrys, il utilise la radiographie pour illustrer quelques-uns des thèmes les plus épineux de cette société de La Havane en prise avec bien des problèmes : désir de partir, prostitution, et bureaucratie. La chilienne Carla Yovane Pérez donne quant à elle une vision personnelle, douce et intimiste, d'hommes prostitués chiliens.

Quant aux canons du féminin, ils sont mis en scène par Noncedo Gxekwa de Johannesburg, elle revendique une esthétique de studio distanciée proche de la mode, tandis qu'une autre chilienne, Zaida González Ríos mêle dans ses auto-mises en scène les cycles de la vie et de la mort, le réalisme et le mysticisme, la colorisation et le kitch, au service d'une critique sociale très virulente, dans une outrance provocatrice et libératoire mettant à mal les clichés du féminin. Le français Fabien Dupoux profite d'un opéra chinois suivi à Vientiane au Laos en 2015 pour observer dans les sociétés du sud-est asiatique leur ouverture sur l'homo et le transgenre.

\section{La conceptualisation}

Une première table ronde réunit en 2017 Grégory Tuban, un géographe qui fait retour sur les frontières de la Ille République, un historien, Guillaume Lacquement qui revient sur la géographie de la frontière inter-allemande [Figure 10] et Mathilde Pette une sociologue qui commente du point de 


\section{Return to History under the aegis of Walter Benjamin}

In 2018 a collaboration is established with the Memorial of the Camp of Rivesaltes which proposes to host an artist in residence. This camp was the main internment camp of the southern zone from 1941 for Spanish Republicans, foreign Jews, and gypsies, then a deposit center for Axis prisoners of war from 1944 to 1948, and from 1962 a transit camp for Harkis and their families.

First of the residents, Laetitia Tura creates her series Notre affaire est de passer en traçant des chemins sur la mer (Our Business is to Pass by Tracing Paths on the Sea) [Figure 11]. The meeting of young survivors of the Open Arms, the SeaWatch, or the Salvamento, who arrived in Perpignan from Africa, gives the artist the opportunity to make the link with the families who fought against fascism during the Spanish war. In 1939, 450,000 people made their way to the Retirada. Philippe Dollo is also attached to Ce souvenir là (This Memory There) [Figure 12] he exposes the archives of the maternity of Elne and the Spanish center of Cerbère which were refuges, places of solidarity, and mutual aid. The photographs of the heritage of the town, the drawings of children of the time are confronted with the places captured today by his camera.

After seven years of exile in various European countries, Walter Benjamin, exhausted, arrived in Portbou at the end of September 1940, a few days after having fled Paris the day after the Nazis entered the capital. To bear

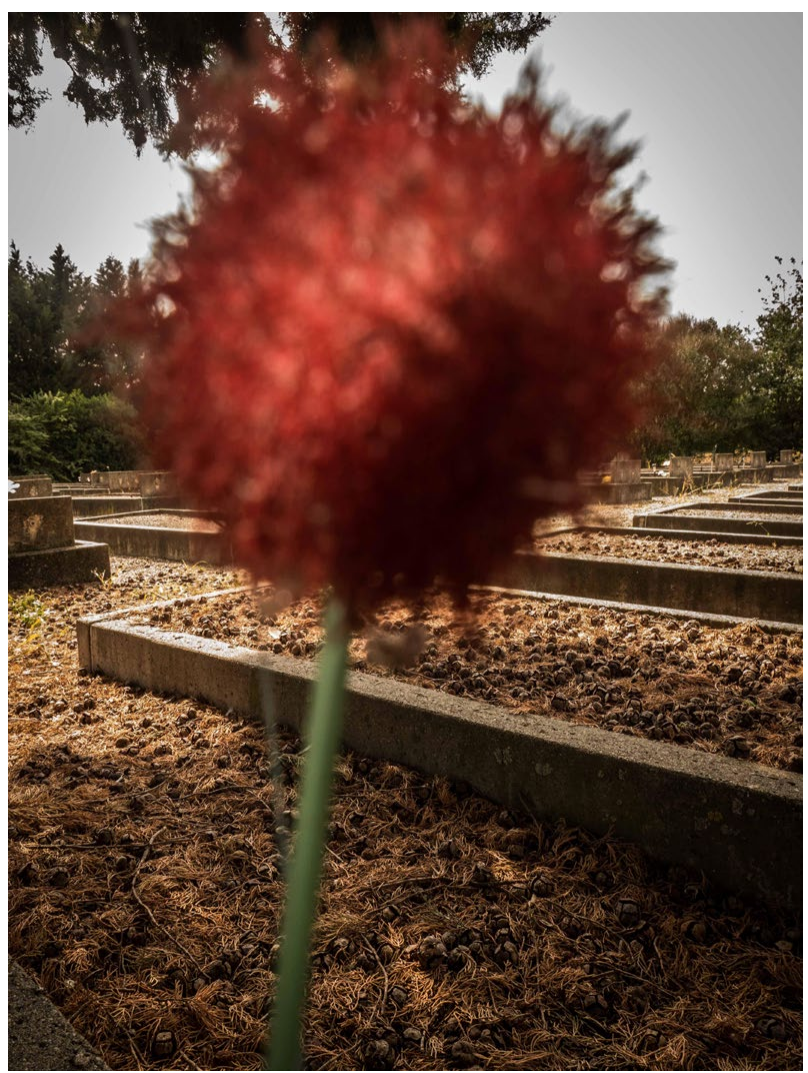

Figure 12. Ce souvenir là. (c) Philippe Dollo. Courtesy of the artist and Fotolimo vue des sciences humaines les flux migratoires contemporains à partir de Calais notamment. En 2019, la parole est donnée à Claire Rodier auteure de Xénophobie Business, aux éditions La découverte où elle analyse le marché mondial de la sécurité de plus en plus privatisée, sécurisation des frontières (dispositifs de surveillance, informatisation des visas et des passeports...) à la gestion des centres de détention et l'escorte des expulsés.

\section{Diverses techniques et esthétiques}

En 2020, invité à donner une conférence par Patric Clanet, en charge du pôle recherche de Fotolimo et Pilar Parcerisas directrice de l'Ecole d'été Walter Benjamin Cerbère - Portbou, partenaire du Festival depuis deux ans, je l'ai intitulée : De la photographie des frontières aux frontières de la photographie. En dehors de mes propres intérêts critiques, j’y ai été incité par la diversité des techniques et esthétiques exposées. Une graphiste montpelliéraine propose sous le label Débit de Beau ses collages en tant que photo-trafics pour autant de Combats symboliques. Camille Carbonaro opère des montages d'archives personnelles pour son œuvre Appelle moi Victoria en quête de ses racines italiennes. Jan Lemitz instrumentalise des Google Views pour scruter ses Innocent Passages. Manuel Benchetrit photographie les affiches de projets architecturaux pour dédoubler L'épiderme de la ville. Salvatore Puglia réactive une lettre d'Hölderlin dans une série photo-texte qui gère son Transit dans un road-movie photographique. Caitriona Dunnett traite la frontière avec le procédé archaïque du cyanotype qui rend plus présents les Mass Paths irlandais. Francesca di Bonito expose ses reliquaires confectionnés à partir d'archives web anonymes intégrés à des coquillages. La pratique performative du chinois Ning Zuohong le voit procéder à l'installation d'un fil rouge comme lien symbolique dans les paysages trans-frontaliers.

\section{Retour sur l'Histoire sous l'égide de Walter Benjamin}

En 2018, une collaboration s'établit avec le Mémorial du Camp de Rivesaltes qui propose d'accueillir un artiste en résidence. Ce camp a été tour à tour principal camp d'internement de la zone sud à partir de 1941 pour les républicains espagnols, les juifs étrangers et les tsiganes, puis un centre de dépôt de prisonniers de guerre de l'Axe de 1944 à 1948 et à partir de 1962, un camp de transit des Harkis et leurs familles.

Première des résidentes, Laetitia Tura réalise sa série Notre affaire est de passer en traçant des chemins sur la mer [Figure 11]. La rencontre de jeunes rescapés de l'Open Arms, du SeaWatch ou du Salvamento, arrivés à Perpignan depuis l'Afrique, donne l'occasion à l'artiste de faire le lien avec les familles qui ont lutté contre le fascisme pendant la guerre d'Espagne. En 1939, 450000 personnes font le chemin de la Retirada. Philippe Dollo s'attache aussi à Ce souvenir là [Figure 12], il expose les archives de la maternité d'Elne et du centre espagnol de Cerbère qui ont été des refuges, des lieux de solidarité et d'entraide. Les photographies du fonds patrimonial de la commune, les dessins d'enfants de l'époque se confrontent aux lieux saisis aujourd'hui par son appareil.

Après sept ans d'exil dans différents pays d'Europe, Walter Benjamin, épuisé, arrive à Portbou fin septembre 1940 
witness to this, I could only project images from the series Konstellation Benjamin (2005-2009), a work by Arno Gisinger, artist and teacher-researcher, developed with the philosopher Nathalie Raoux. They focus on the years of exile of the German philosopher. From Berlin 1933 to Portbou 1940: thirty-six still images taken by the photographer during Walter Benjamin's years of exile bear witness to the current state of these places and non-places of memory, accompanied by a quote from his correspondence.

Upon arrival at the Spanish border, Benjamin carried in his luggage a copy of the original entrusted to the writer Georges Bataille, then secretary of the National Library at the Cabinet of Medals, his essay: Theses on the Philosophy of History. He comments there the word according to which "the historian is a prophet who looks back" he is the angel of the history. He defined it thus:

There is a painting by Klee called Angelus Novus. It shows an angel who seems to be moving away from something to which his gaze seems to be fixed. His eyes are wide open, his mouth is open and his wings are spread. This should be the appearance of the Angel of History.

Benjamin considers history from the reverse side of official history: that of the victims, the dominated, the catastrophes.

Today, when museums and places of culture are closed and the pandemic poses sanitary borders that are more restrictive than ever before in history, making borders with artworks is more necessary than ever. The people in charge of Fotolimo prepared with modesty but great resolution their edition for the fall of 2021. quelques jours après avoir fui Paris au lendemain de l'entrée des nazis dans la capitale. Pour en témoigner, je ne pouvais que projeter les images de la série Konstellation Benjamin (20052009), œuvre d'Arno Gisinger, artiste et enseignant chercheur, élaborée avec la philosophe Nathalie Raoux. Elles portent sur les années d'exil du philosophe allemand. De Berlin 1933 à Portbou 1940 : trente-six arrêts sur image du photographe découpés dans les années d'exil de Walter Benjamin témoignent de l'état actuel de ces lieux et non-lieux de mémoire, accompagnés d'une citation de sa correspondance.

A l'arrivée à la frontière espagnole Benjamin portait dans son bagage une copie de l'original confié à l'écrivain Georges Bataille alors secrétaire de la Bibliothèque nationale au Cabinet des médailles. son essai : Thèses sur la philosophie de l'histoire. II y commente le mot selon lequel « l'historien est un prophète qui regarde en arrière », il est l'ange de l'histoire. Il le définissait ainsi.

Il y a un tableau de Klee dénommé Angelus Novus. On y voit un ange qui a l'air de s'éloigner de quelque chose à quoi son regard semble rester rivé. Ses yeux sont écarquillés, sa bouche est ouverte et ses ailes sont déployées. Tel devra être l'aspect que présente l'Ange de l'Histoire.

Benjamin envisage l'histoire à partir de l'envers de l'histoire officielle : celle des victimes, des dominés, des catastrophes.

Aujourd'hui que les musées et les lieux de culture sont fermés alors que la pandémie pose mondialement des frontières sanitaires plus contraignantes que jamais dans l'Histoire, faire frontière avec des œuvres est plus que jamais nécessaire. Les responsables de Fotolimo préparent avec modestie mais grande résolution leur édition pour l'automne 2021. 